Heftets tittel:

Utgitt:

Publikasjonsnummer:

\section{IS- 1944}

ISBN-nr. 978-82-8081-239-1

Nasjonal veileder pleie og omsorg
Pasienter med CFS/ME: Utredning, diagnostikk, behandling, rehabilitering,

02/2014, oppdatert 2015 på bakgrunn av innspillsrunde 2014

Helsedirektoratet

Avdeling rehabilitering og sjeldne tilstander

Pb. 7000 St Olavs plass, 0130 Oslo

Universitetsgata 2, Oslo

TIf.: 81020050

Faks: 24163001

www.helsedirektoratet.no

Heftet finnes elektronisk på www.helsedirektoratet.no:

https://helsedirektoratet.no/retningslinjer/nasjonal-veileder-pasienter-med-cfsme-utredningdiagnostikk-behandling-pleie-og-omsorg

Forfattere: $\quad$ Avdeling rehabilitering og sjeldne tilstander

Trykk og layout: $\quad$ Andvord Grafisk as 


\section{Forord}

Helsedirektoratet har «følge med ansvar» for å vurdere utvikling av tjenestetilbud og om dette står i forhold til pasientgruppenes behov.

På bakgrunn av erfaringer fra kontakter med pasienter, pårørende og fagpersoner er direktoratet gjort kjent med at barn, unge og voksne med CFS/ME og deres pårørende møter store utfordringer som i for liten grad ivaretas av tjenesteapparatet.

Helsedirektoratets mål med denne veilederen er å bidra til faglig forsvarlighet, god kvalitet på tjenestene og tilnærmet likhet i tilbudet uansett hvor man bor som pasient med CFS/ME.

Å gi helsetjenester til brukere som ikke har en klar og entydig anerkjent årsak til sin sykdom, stiller store krav til faglig kvalitet, profesjonalitet og utøvelse av tjenestetilbudet. Tidlig og riktig diagnose er viktig i et pasientforløp.

Mange pasienter oppgir at de får et bedre liv når de har fått korrekt diagnose, aksepterer sykdommen og lærer seg gode mestringsstrategier for de utfordringer CFS/ME kan gi.

Veilederen er utarbeidet slik at den favner et bredt felt av temaer.

Veilederen bygger på dagens kunnskap og erfaring, de ordninger som er etablert i dag og gjeldende rettsregler. Det er lagt vekt på at dette først og fremst skal være en faglig veileder for helsepersonell.

Veilederen vil bli revidert i takt med ny kunnskap.

Oslo, februar 2014

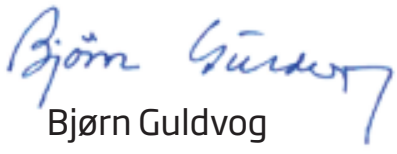

helsedirektør

\section{Avog til kurere Ofte lindre Alltid troste}

Hippokrates 


\section{Innhold}

Forord

Innledning

$1 \quad$ Hva er CFS/ME?

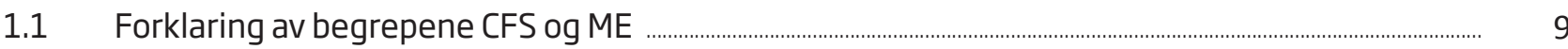

1.2 Diagnostiske systemer og kriterier .................................................................................................................................. 9

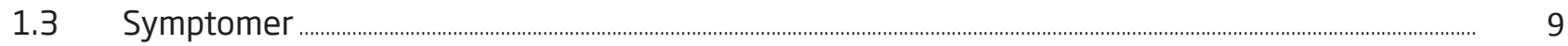

1.4 Alvorlighetsgrad og funksjonsnivå .......................................................................................................................... 12

1.A Figure 1a-Comparison of SF-36v2TM in men with ME/CFS, other health conditions and healthy.

1.B Figure 1b-Comparison of SF-36v2TM in women with ME/CFS, other health conditions and healthy.

1.5 Forekomst...

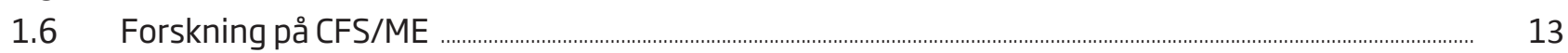

$2 \quad H v o r d a n$ stilles diagnosen?

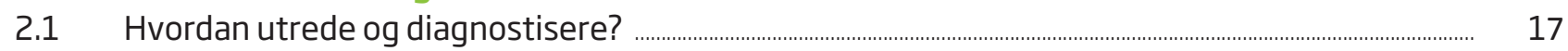

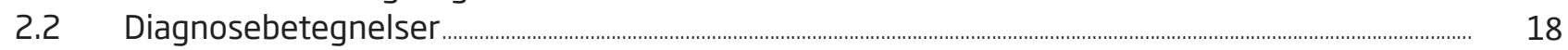

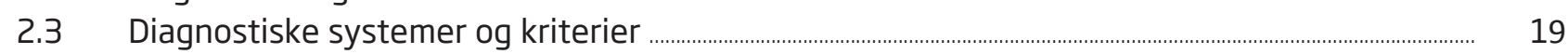

2.4 Fukudakriteriene (CDC-kriteriene 1994) ...................................................................................................... 19

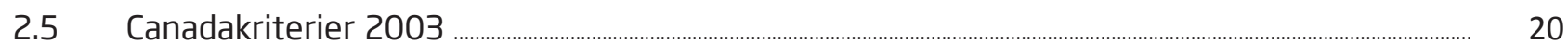

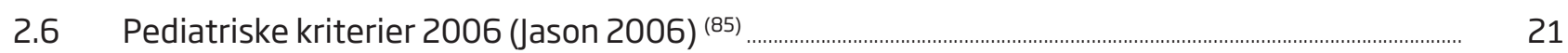

$3 \quad$ Behandling, rehabilitering og tilrettelegging .................................................................................... 23

3.1 Behandling og symptomlindring ........................................................................................................................ 24

3.2 Begrepsforklaringer i forhold til ulike behandlings-/mestringstilbud .............................................................. 25

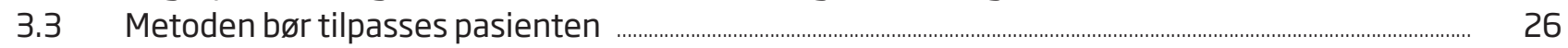

3.4 Medikamentell og ikke-medikamentell symptomlindring .......................................................................... 27

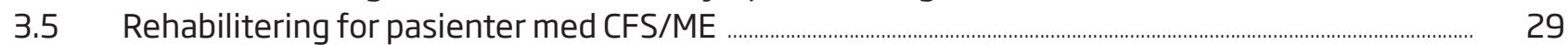

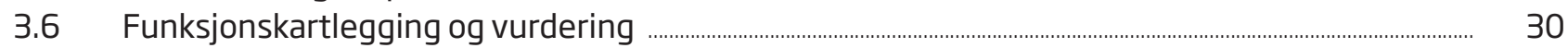

3.7 Rehabilitering med arbeid/utdanning som mål .................................................................................................. 32

3.8 Barn, ungdom og unge voksne ............................................................................................................ 32

3.9 Oppfølging av pasienter med pleie- og omsorgsbehov basert på erfaringer og eksempler

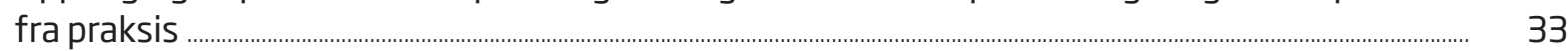

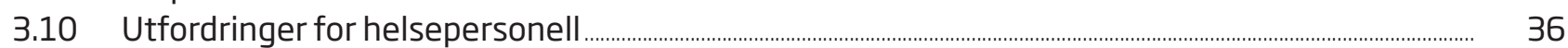

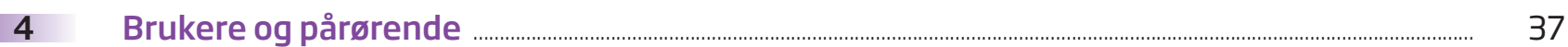

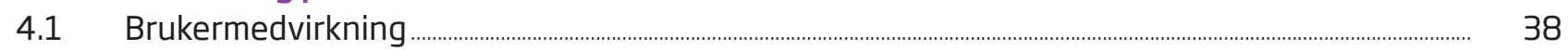

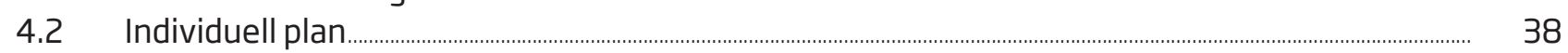

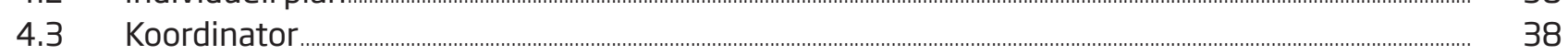

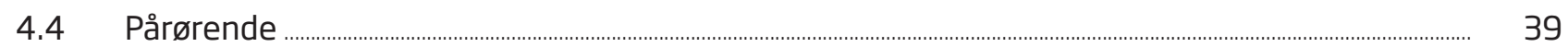

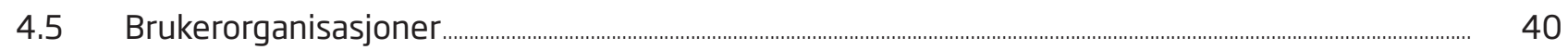

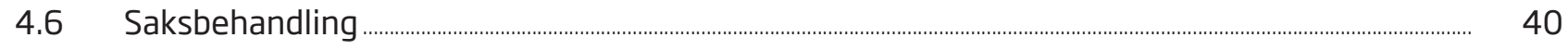

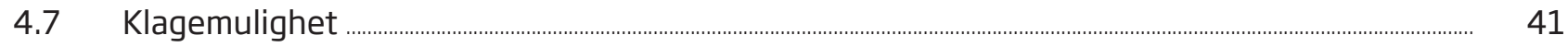

4.8 Pasient- og brukerombudet ......................................................................................................................................... 41 


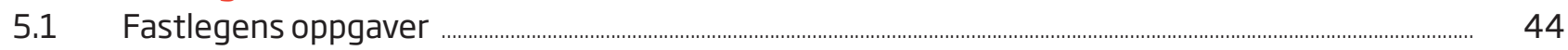

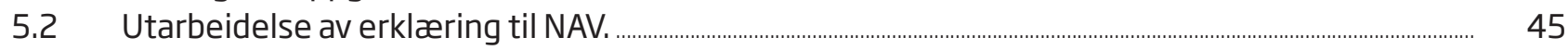

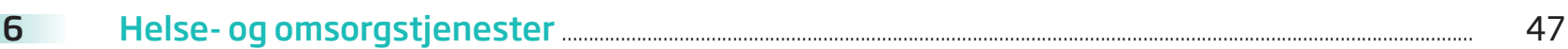

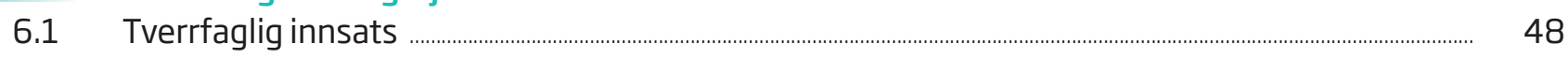

6.2 Faggrupper som kan inngå i oppfølging av pasienter med CFS/ME ................................................................. 49

6.3 Spesialisthelsetjenestens rolle ........................................................................................................................................ 51

6.4 Nasjonal kompetansetjeneste ............................................................................................................................................... 51

6.5 Ambulant virksomhet og veiledning til kommunene......................................................................................... 52

6.6 Spesialisthelsetjenestens tilbud ...................................................................................................................................... 52

6.7 Tilrettelegging ved døgnopphold ................................................................................................................................ 54

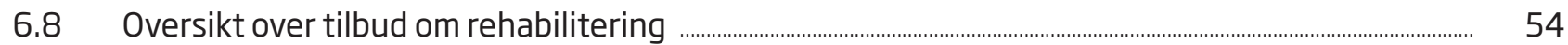

6.9 Private institusjoner med offentlig avtale ..................................................................................................................... 55

$7 \quad$ Kvalitet, faglig forsvarlighet og kunnskapsbasert praksis ........................................................................... 57

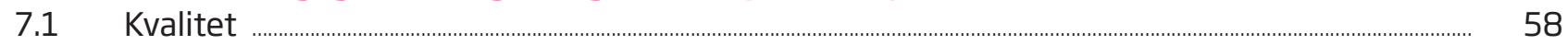

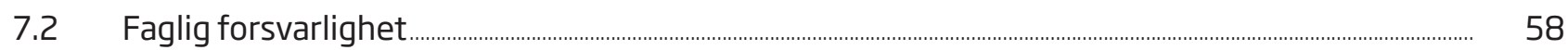

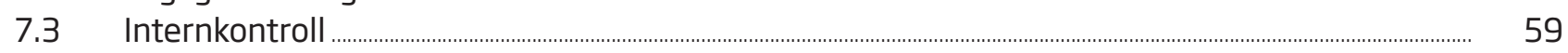

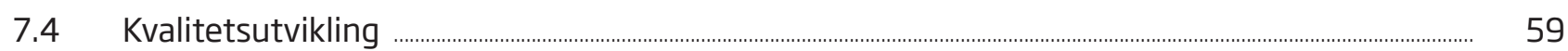

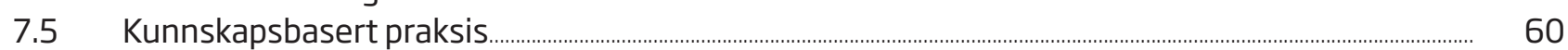

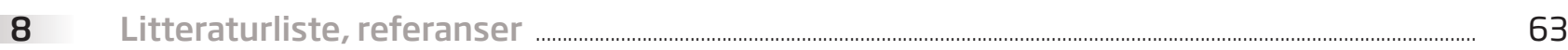

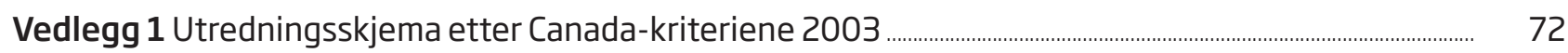

Vedlegg 2 Utredningsskjema etter CDC1994 Fukudakriteriene ......................................................................................... 74

Vedlegg 3 Utredningsskjema i henhold til Pediatrisk kriterier (Jason, 2006) ........................................................... 75 


\section{Innledning}

Helsedirektoratet fikk 1.11.2011 i oppdrag fra Helse- og omsorgsdepartementet å:

«utarbeide rundskriv/veileder om diagnostisering og oppfølging av pasienter med ulik grad av CFS/ME, herunder barn og ungdom, i samarbeid med relevante fagmiljøer og en evt. framtidig nasjonal kompetansetjeneste, og i dialog med berørte brukerorganisasjoner».

Denne veilederen er svar på oppdraget. Den er utarbeidet slik at det favner et bredt felt av temaer, og målgruppen er alle som arbeider med og/eller er berørt av CFS/ME. Gode tjenester til pasienter med CFS/ME forutsetter at instansene og profesjonene jobber tett sammen både med hverandre, med pasientene og de pårørende for å kunne ivareta den enkelte.

\section{Mål og målgruppe}

Helsedirektoratets mål med veilederen er å bidra til faglig forsvarlighet, samt likhet i tilbud og god kvalitet på tjenestene til pasienter med CFS/ME, både i spesialisthelsetjenesten og i primærhelsetjenesten.

\section{Direktoratets «følge med»-rolle}

Helsedirektoratet har et «følge med ansvar». Dette betyr blant annet å vurdere utviklingen av helsetjenestetilbud, og om dette står i forhold til pasientgruppenes behov. Erfaringer fra og kontakt med pasienter, pårørende og fagpersoner viser at barn, unge og voksne med CFS/ME og deres pårørende møter store utfordringer, og i for liten grad ivaretas godt av et samlet tjenesteapparat.

\section{Innsats for pasienter med CFS/ME}

Det har vært en betydelig nasjonal satsing gjennom flere år på målrettede tiltak for å styrke helsetilbudet til pasienter med kronisk utmattelsessyndrom/Myalgisk encefalopati (CFS/ME).

Siden 2007 er det bevilget 5 mill. kroner årlig for å sikre nasjonal kompetanseoppbygging og for å styrke tilbudet til pasientgruppen. Midlene er forvaltet av Helsedirektoratet, som har gitt støtte til en rekke informasjonstiltak og fagutviklingsprosjekter i kommune- og spesialisthelsetjenesten. Helsedirektoratet opprettet i 2007 et nasjonalt kompetansenettverk, der brukere og fagfolk kunne møtes.

Kompetansenettverket ble erstattet med Helsedirektoratets fagråd for CFS/ME i 2010. Tiltak som kan bidra til bedre utredning, behandling, pleie og omsorg for barn og unge, og til de aller sykeste pasientene har de siste årene vært prioritert. Det pågår, i 2013, prosjekter der det legges vekt på å bygge opp modeller for gode pasientforløp med samhandling mellom brukere, spesialisthelsetjeneste, primærhelsetjenesten, lærings- og mestringsentre og andre aktører. Mange pasienter har behov for tjenester i et samspill mellom kommunale helse- og omsorgstjenester og spesialisthelsetjenesten. Erfaringer fra slike prosjekter, blir viktige for videre anbefalinger for henvisningsrutiner, diagnoseutredning og samhandling mellom nivåene i helsetjenesten og andre tjenesteytere $i$ andre etater (eksempelvis NAV, utdanningssektoren). Som et ledd i informasjonsarbeidet har Helsedirektoratet utviklet en egen nettside om CFS/ME. http://www.helsedirektoratet.no/helse-og-omsorgstjenester/cfsme/Sider/default.aspx

\section{Statusgjennomgang og forskningsbasert kunnskapsgrunnlag}

På oppdrag fra Helse- og omsorgsdepartementet ble Helsedirektoratet i 2010 bedt om å gjøre en oppsummering av ny kunnskap og evaluere den nasjonale satsingen. For å besvare oppdraget bestilte Helsedirektoratet to rapporter: èn fra SINTEF og èn fra Nasjonalt kunnskapssenter for helsetjenesten.

1) SINTEFs statusgjennomgang 2010 oppsummerte:

- Det er mangel på kunnskap om CFS/ME i sosial-velferds- og helsetjenesten. Få kommuner har tilbud som ivaretar behovene hos pasienter med CFS/ME. 
- Flere av helseforetakene har ikke bygget opp noe spesifikt tilbud til pasienter med CFS/ME.

- Det er manglende enighet om og implementering av diagnostiske kriterier for CFS/ME.

- Det er mangel på kurativ behandling av CFS/ME.

- Det er mangel på egnede behandlings-, rehabiliterings- og omsorgstilbud for de dårligst fungerende med CFS/ME. Planene om etablering av tilbud til de aller sykeste med CFS/ME ved Oslo Universitetssykehus er ennå ikke realisert.

- Det er mangelfull kompetanse og mangelfullt tilbud når det gjelder de spesielle utfordringene knyttet til barn og unge med CFS/ME.

2) Nasjonalt kunnskapssenter for helsetjenesten oppsummerer hovedfunn for forskningsbasert kunnskapsgrunnlag i notat fra 2011: http://www.kunnskapssenteret.no/publikasjoner/behandling-avkronisk-utmattelsessyndrom-cfs-me

- Deltagelse i arbeidsliv og skole: Kognitiv atferdsterapi gir muligens noe økning i arbeidslivsdeltakelse sammenlignet med standard behandling.

- Utmattelse: Kognitiv atferdsterapi eller treningsbehandling gir trolig mindre utmattelse sammenlignet med henholdsvis standard behandling eller avspenning og tøyning. Det er begrenset med tilgjengelig dokumentasjon om effekt av farmakologisk behandling på grad av utmattelse.

- Livskvalitet: Kognitiv atferdsterapi gir muligens litt bedre livskvalitet sammenlignet med standard behandling eller annen psykoterapi. Det er usikkert om treningsbehandling sammenlignet med avspenning og/eller tøyning påvirker helserelatert livskvalitet. I beste fall kan treningsbehandling ha stor positiv effekt, i verste fall kan treningsbehandling ha liten eller ingen innvirkning på livskvalitet.

- Kvaliteten på dokumentasjonen er for mangelfull til at vi kan trekke konklusjoner om effekt av kosttilskudd og alternativ

- Det er behov for å oppsummere effekter av tiltak innen pleie og omsorg samt rehabilitering.

«Under utarbeidelsen av denne rapporten søkte vi utelukkende etter systematiske oversikter publisert fra og med 2005, og vi fant da ingen oversikter som omhandlet effekt av aktivitetsavpasning, avspenning, eller pleie- og omsorgstiltak. Det er mulig at det finnes systematiske oversikter om effekt av disse tiltakene publisert før 2005, men siden disse oversiktene etter alt å dømme vil være utdaterte er det behov for å søke etter primærstudier og lage systematiske oversikter dersom vi ønsker klare svar på effekt av disse tiltakene. Det samme gjelder effekt av tiltak blant de aller sykeste samt blant barn og unge med kronisk utmattelsessyndrom, for vi har ikke identifisert systematiske oversikter som søker å besvare spørsmål om effekt av tiltak blant disse pasientgruppene.»

Fra januar 2012 har Helse- og omsorgsdepartementet gitt godkjenning for opprettelse av Nasjonal kompetansetjeneste for CFS/ME. Helse Sør-Øst RHF er gitt ansvaret for tjenesten, og Oslo universitetssykehus har etablert tjenesten. Tjenesten drives etter kravene i forskrift om godkjenning av sykehus, bruk av betegnelsen universitetssykehus og nasjonale tjenester i spesialisthelsetjenesten, §ऽ 4-5 og 4-6

http://www.lovdata.no/for/sf/ho/ho-20101217-1706.htm/ og tilhørende veileder http://www.regjeringen.no/upload/HOD/SHA/Veiledernasjonaletjenester01022013b.pdf

Helsedirektoratet har siden sommeren 2011 arbeidet med en veileder til fastleger, helse- og omsorgstjenestene i kommunene og til spesialisthelsetjenesten. I SINTEFs rapport ble det beskrevet et fagfelt med mange aktører med ulike tilnærminger til CFS/ME. Uenighetene knytter seg blant annet til årsak og navn på tilstanden, bruk av diagnoseverktøy og anbefalt behandling. Det er et kjent fenomen fra andre diagnosegrupper som ikke har en klar årsak, eller kan diagnostiseres med en enkel laboratorietest, at involverte aktører kan ha ulik tilnærming til håndtering av pasientene. Et eksempel er Minimal Brain Dysfunction, MBD. Dette startet som en diagnose, men utgjør i dag flere ulike diagnoser, med behov for ulike behandlings- og oppfølgingsformer. Helsedirektoratet kan ikke utelukke at det er likedan i forhold til diagnosen som i dag omtales som CFS/ME. For mange diagnoser har kriterier i årenes løp blitt innskjerpet for å finne de «riktige pasientene». Det har ofte medført at kriteriene har blitt mer kompliserte. 
Spørreskjema og flytskjema utarbeides til bruk som hjelp for å lette diagnostiseringen. Gjennomgangen fra Kunnskapssenteret viser at det har vært en utvikling av nye diagnostiske verktøy gjennom flere år. Fra flere hold er det nå også ytret et ønske om å se på om det er tjenlig å skille mellom CFS og ME. Det er fremsatt hypoteser om at dette kan være ulike tilstander som derfor krever ulike behandling. Konsensus om hvilke diagnostiske kriterier en skal benytte for å få mer entydige svar i forhold til forskning, utredning og behandling må være et mål. Den Nasjonale kompetansetjenesten får her en viktig oppgave.

Det siste publiserte diagnoseverktøyet er ICC fra 2011 som er utviklet for ME diagnostikk. Helsedirektoratet er åpen for at det fortsatt kan ta tid før det endelige diagnostiske verktøyet foreligger, men anser at ICC kan være et steg på veien. Flere avdelinger i spesialisthelsetjenesten melder om pågående valideringsprosjekt av noen utvalgte kriterier. En klarere avgrensing innen pasientgruppen, vil medføre at færre får CFS/ME diagnose. Utfordringen da blir å sørge for at de som faller utenfor kriteriene også får adekvat og riktig oppfølging.

Helsedirektoratet har ønsket en god dialog med sentrale aktører, for å oppnå en best mulig veileder. I arbeidet med dokumentet har Helsedirektoratet hatt kontakt med en rekke instanser, fagfolk, og brukere som har ulik tilnærming til CFS/ME. Representantene i Helsedirektoratets fagråd har noe ulik tilnærming til fagfeltet, men har gitt gode og viktige innspill. Det har tatt lang tid å få denne veilederen ferdig, og det er to årsaker til det. For det første er det brukt mye tid på å snakke med enkeltpasienter, pårørende, representanter for pasientforeninger og helsepersonell for å sikre tilstrekkelig bredde og forankring . Deretter har veilederen vært på bred, ekstern høring. Tilbakemeldingene har vært mange, og svært omfattende. Alle høringsinnspill og synspunkter er gjennomgått og er grundig vurdert. Noen innspill har bidratt til viktige endringer og presiseringer, og andre har gitt relevant kunnskap inn i saken, selv om det ikke er naturlig at de er referert i et dokument som veilederen. Prosessen med å ferdigstille veilederen etter de siste høringsinnspillene har derfor vært krevende. Høringsinnspillene har vært sprikende, og de har tydeliggjort uenighetene i fagmiljøene, og blant pasienter.

Nasjonal kompetansetjeneste for CFS/ME er etablert på Oslo universitetssykehus (OUS). For Helsedirektoratet har det vært naturlig å innhente deres fagekspertise i sluttføringen av veilederen. Dette er i tråd med føringer fra Helse- og omsorgsdepartementet. I veilederen har direktoratet forsøkt å sammenstille foreliggende evidensbasert kunnskap og erfaringsbasert kunnskap. Det har vært nødvendig å synliggjøre uenigheter, men også komme med eksempler som har bidratt til gode pasientforløp.

Dokumentet er planlagt revidert i takt med ny kunnskap og erfaringer fra brukerne av det.

I etterkant av utgivelsen av denne veilederen ble det reist kritikk fra enkelte hold om deler av innholdet. Kritikken har hovedsakelig dreid seg om de 10 generaliserte eksemplene på tilpasninger som kan benyttes ved pleie og omsorg for brukere med alvorlig grad av CFS/ME. Disse eksemplene er tatt inn i kapittel 3 som omhandler behandling, rehabilitering og tilrettelegging. På bakgrunn av kritikken, og for å høste erfaringer etter at veilederen hadde vært i bruk en periode, ble de opprinnelige høringsinstansene i juli 2014 invitert til å komme med innspill til direktoratet. Den nasjonale veilederen er så justert noe i tråd med de innspillene som kom inn. Direktoratet har ikke gjort en oppdatert kunnskapsoppsummering i denne utgaven av veilederen. Dette er imidlertid gjort i en nyere amerikansk rapport, som omtales nedenfor. Alle endringer i denne veilederen er satt $i$ kursiv, og merket med: (Mai 2015).

Institute of Medicine of the National Academies i USA, ga i 2015 ut en rapport; "Beyond Myalgic Encephalomyelitis/Chronic Fatigue Syndrome, Redefining an IIIness".

http://books.nap.edu/openbook.php?record_id=19012

Rapporten bygger på et arbeid utført av en gruppe nedsatt av IOM, og gruppens mandat var å evaluere dagens diagnosesystemer og å utvikle evidens-baserte kliniske diagnostiske kriterier for ME-CFS/ME. Videre skulle gruppen vurdere om ny terminologi skulle tas i bruk, og utvikle et verktøy for å spre kunnskap om de nye kriteriene til helsearbeidere. Gruppen skulle ikke ta stilling til årsak til sykdommen, sykdomsmekanismer eller behandling av sykdommen. 
Rapporten gir en god oversikt over bl.a. historikk, definisjoner, diagnose, symptomer, kriterier og kunnskapsgrunnlaget dette bygger på. Rapporten presenterer fire anbefalinger:

- Det er utarbeidet, foreslått og anbefalt et nytt sett med kriterier for diagnostisering av sykdommen. Diagnosen bør få en ny kode i ICD-10 som ikke er knyttet opp mot kronisk tretthet eller nevrasteni.

- Det bør utvikles et utrednings og oppfølgingsverktøy, etter en tverrfaglig modell som omfatter både primær og spesialisthelsetjenesten, innenfor somatikk så vel som psykisk helse, for å sikre gode pasientforløp.

- Diagnosekriteriene bør evalueres innen fem år.

- Det foreslås et navnebytte til «Systemic exertion intolerance disease», (SEID), som direkte oversatt blir "systemisk anstrengelses intoleranse sykdom".

Helsedirektoratet mener at det er positivt at det har blitt gjort en så grundig og uavhengig kunnskapsgjennomgang. Direktoratet stiller seg også positive til de fire anbefalingene, men mener at det må brukes tid på validering av disse og for å se på effekter av endringene før de kan anbefales av helsemyndighetene.

Helsetjenesten nasjonalt oppfordres til å arbeide med validering av kriteriene. (Mai 2015) 


\section{1}

\section{Hva er CFS/ME?}

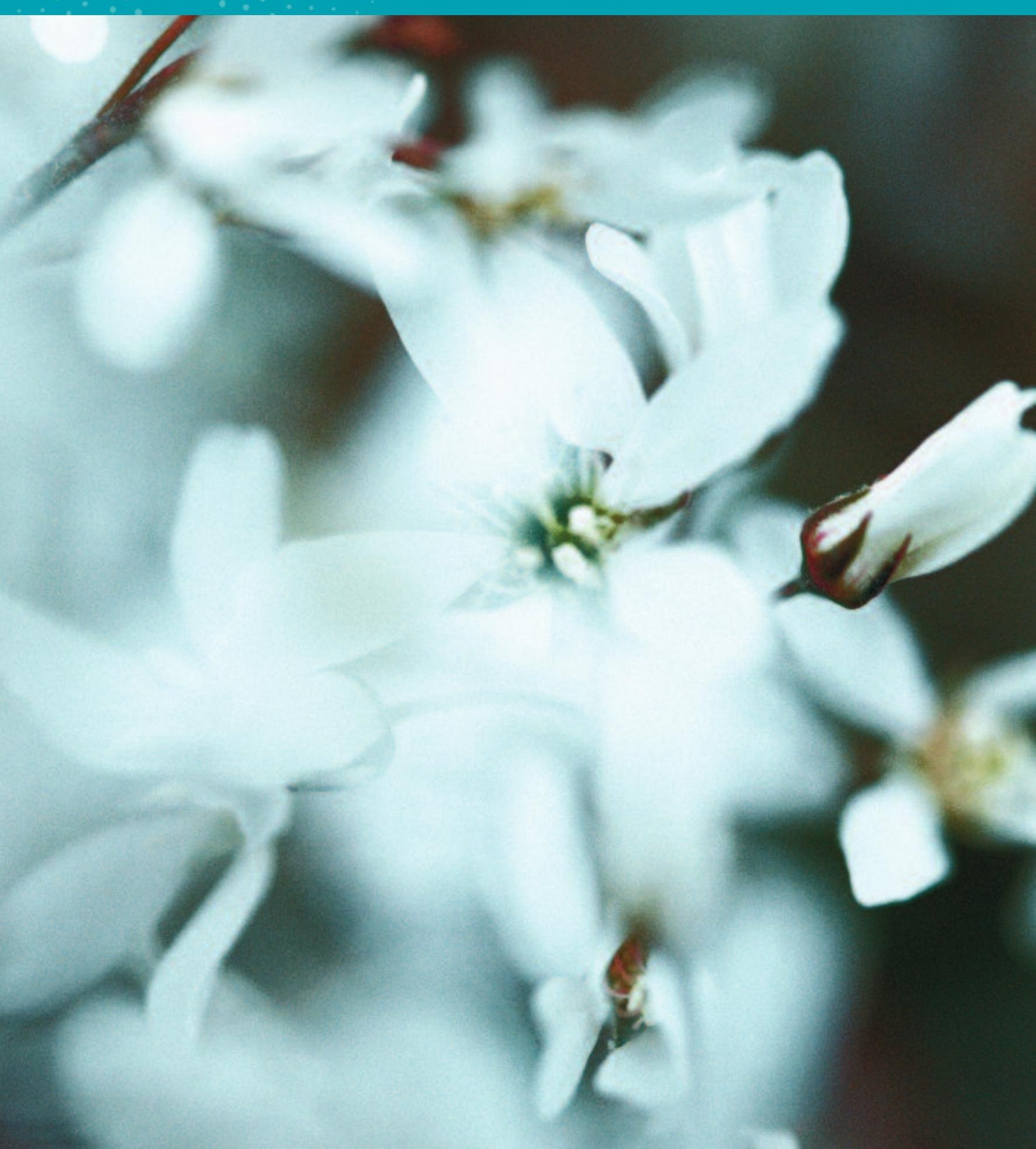


CFS/ME er en tilstand uten sikker og entydig etiologi. Pasientgruppen er heterogen, men pasientene har til felles at de har en langvarig, betydelig, og til tider invalidiserende utmattelse og karakteristiske tilleggssymptomer. Utmattelsen forverres av mental, sosial eller fysisk anstrengelse og lindres ikke som normalt av hvile. Forverrelsen kan være forsinket med timer eller mer, og restitusjonstiden er forlenget. Generaliserte smerter, søvnforstyrrelser og kognitive problemer er noen av de typiske tilleggssymptomene.

\subsection{Forklaring av begrepene CFS og ME}

CFS, Chronic fatigue syndrom, betyr «kronisk utmattelsessyndrom».

ME, Myalgic encephalomyelitis oversettes til «myalgisk encefalomyelitt» på norsk, men betegnelsen «myalgisk encefalopati» brukes også. Myalgi betyr «muskelsmerter», encefalon kommer fra gresk og betyr «hjerne», myelon betyr «ryggmarg». Pati betyr «lidelse» og itt står for «betennelse».

I litteraturen brukes begrepene ME og CFS vanligvis synonymt eller i kombinasjon som ME/CFS eller CFS/ME. Mange pasienter foretrekker benevnelsen «myalgisk encefalopati», fordi de mener at begrepet «kronisk utmattelsessyndrom» trivialiserer tilstanden. På den annen side har begrepet «ME» blitt kritisert fordi det ikke er påvist sykdom i hjernen og ryggmargen hos pasientgruppen (1). Nå for tiden brukes gjerne begge navnene som et kompromiss og anerkjennelse av begge synspunktene. I denne veilederen vil vi bruke betegnelsen CFS/ME.

På grunn av manglende kunnskap om årsaksforholdene ved CFS/ME, er det heller ikke enighet i fagmiljøene om hvorvidt man skal betegne CFS/ME som en tilstand eller en sykdom. En forventer at begrepsbruken vil bli mer entydig når mekanismene bak CFS/ME blir bedre kartlagt. I denne veilederen betegnes CFS/ME som en sykdom.

En rekke tilstander og sykdommer kan gi kronisk tretthet eller utmattelse. I en norsk befolkningsstudie rapporterte 11,4 \% kronisk tretthet og slitenhet (2). Mange medikamenter kan også gi tretthet som bivirkning. Dette er ikke det samme som CFS/ME, og en viktig del av utredningen ved CFS/ME består i å skille mellom det karakteristiske sykdomsbildet ved CFS/ME og andre årsaker til kronisk tretthet.

\subsection{Diagnostiske systemer og kriterier}

Det har vært benyttet ulike diagnostiske systemer og kriterier for å fastsette diagnosen. De ulike systemene og kriteriene er nærmere beskrevet i kapittel 2 .

\subsection{Symptomer}

I tillegg til at det foreligger en uforklarlig utmattelse som nedsetter funksjonsnivået betydelig i forhold til tidligere, har pasientene som regel en rekke forskjellige fysiske og kognitive symptomer. Langvarig forverring av utmattelsen etter fysisk eller mental anstrengelse anses som et kardinalsymptom ${ }^{(3)}$. På engelsk brukes begrepet «postexertional malaise» og forkortelsen PEM. Utmattelsen kan forverres umiddelbart etter en aktivitet eller med en forsinkelse på timer eller dager.

Pasientene har som regel også en rekke tilleggssymptomer, blant annet:

- ikke forfriskende søvn

- smerter (muskelsmerter, smerter i mange ledd, ulike former for hodepine, temporomandibulært smertesyndrom, myofascialt smertesyndrom) 
- kognitive symptomer (svekket hukommelse, redusert konsentrasjonsevne, nedsatt simultankapasitet, ordletingsproblemer, rask kognitiv trettbarhet, distraherbarhet, langsom informasjonsbearbeiding, dårlig korttidsminne)

- autonome forstyrrelser (blodtrykksfall, hjertebank, svimmelhet, postural ortostatisk takykardi syndrom (POTS))

- overfølsomhet for en eller flere typer sanseinntrykk (lys, lyd, smak, lukt, berøring)

- parestesier, nedsatt balanse, klossethet, opplevelse av muskelsvakhet, unormal gange

- irritabel tarm syndrom, interstitiell cystitt, hyppig vannlating, svimmelhet, nummenhet, kvalme, problemer med temperaturreguleringen, Raynauds fenomen, økt tørste, intoleranse for enkelte matvarer eller kjemikalier

- sykdomsfølelse, feberfølelse, tilbakevendende sår hals og ømme lymfeknuter

\section{Hva forårsaker sykdommen?}

Forskningen om CFS/ME har vært preget av uenighet om hvorvidt CFS/ME skal oppfattes primært som en psykisk eller fysisk sykdom. Dette har ført til splittelse i fagmiljøene så vel som strid mellom ulike behandlere, pasientorganisasjoner og helsevesenet. Tendensen tidligere har vært at store deler av fagmiljøet har lagt mest vekt på de psykologiske og kognitive årsakene så vel som behandlingsformene for CFS/ME. Denne utviklingen er i ferd med å snu. I dag forskes det bredt på CFS/ME, både med tanke på biologiske/fysiske årsaksforhold og psykologiske faktorer. Det hersker stort sett enighet om at årsakene til utvikling og opprettholdelse av CFS/ME må forstås som multifaktorielle, og at sykdommen skyldes et samspille mellom biologiske og psykososiale faktorer. Det er imidlertid viktig å være klar over at det er stor heterogenitet i pasientgruppen, og at årsakene til sykdomsutvikling og det kliniske bildet av CFS/ME varierer fra pasient til pasient. Vanligvis skiller man mellom disponerende, utløsende og vedlikeholdende faktorer for CFS/ME:

\section{Disponerende faktorer}

Kvinner rammes betydelig oftere av CFS/ME enn menn, men man vet ikke hvorfor kjønn påvirker sykdomsrisikoen ${ }^{(4,5)}$. Visse personlighetstrekk, blant annet perfeksjonisme, antas å øke sykdomsrisikoen ${ }^{(6-8)}$. Imidlertid knytter det seg flere metodeproblemer til studier av personlighetstrekk og årsakssammenhenger ved CFS/ME. Noen studier antyder en sammenheng mellom alvorlige barndomstraumer og/eller en tidligere historie med PTSD (posttraumatisk stresslidelse) og utvikling av CFS/ME, men studiene er ikke entydige ${ }^{(9-11)}$. Noen studier om CFS/ME rapporterer om stressende livshendelser i månedene forut for debut av sykdommen ${ }^{(12,13)}$. Foreløpig vet man lite om hvilke gener som predisponerer for CFS/ME, men dette er gjenstand for kartlegging $(14,15)$.

\section{Utløsende faktorer}

En rekke studier konkluderer med at infeksjonssykdommer kan utløse CFS/ME. Mange ulike virus-, bakterie- og parasittinfeksjoner er assosiert med sykdomsdebut. Spesielt kjent er mononukleose (kyssesyke, Epstein Barr virus) (16-18). I Norge er epidemien av kronisk tretthet av CFS/ME etter at drikkevannet i Bergen ble forurenset med parasitten Giardia Lamblia, et ofte referert eksempel på infeksjonsutløst CFS/ME (19).

I 2009 ble det publisert en studie som viste funn av retroviruset XMRV hos 2/3 av pasienter med CFS/ME (20). Funnet har senere vist seg å skyldes et laboratorievirus, og forskning i ettertid har konkludert med at det ikke finnes noen holdepunkter for at XMRV kan utløse CFS/ME (21).

Immunologiske studier tyder på avvik i immunreguleringen hos CFS/ME, blant annet i regulering av T-lymfocytter og cytokiner (22-25). Funnene er imidlertid ikke konsistente i ulike studier, og man har ikke kunnet identifisere potensielle immunologiske biomarkører (26). Effekt av rituximab ved CFS/ME, et medikament som fjerner B-celler og brukes ved blant annet lymfomer, leukemi og leddgikt, har gitt opphav til en hypotese om at CFS/ME kan være en autoimmun sykdom, men man har foreløpig ikke funnet andre holdepunkter for dette (27) (Se også 1.4.). 
Autonom dysregulering og endret kardiovaskulær autonom kontroll forekommer hyppig ved CFS/ME, blant annet forstyrrelser i regulering av puls og blodtrykk, blodgjennomstrømning og temperatur (28-30). Det autonome nervesystemet er essensielt i stressregulering, og flere studier tyder på unormale reaksjoner på stress ved CFS/ME (31). Immunsystemet påvirkes blant annet av det autonome nervesystemet. Dette kan støtte oppunder at psykonevroimmunologiske forhold kan spille en rolle ved CFS/ME (32). Hormonelle forstyrrelser er påvist, spesielt for stressfysiologiske mekanismer som involverer HPA-aksen (hypothalamus - hypofyse - binyrebark-aksen) (33,34). Undersøkelser av pasienter med CFS/ME før og etter fysisk anstrengelse, kan tyde på at de har en endret genregulering etter belastning i forhold til friske (35,36).

Billeddiagnostiske og nevropsykologiske tester viser avvikende funn i sentralnervesystemet hos pasienter med CFS/ME (37-43). "Sentral sensitisering" (utvikling av hypersensitivitet for ulike stimuli i sentralnervesystemet), kan være en mekanisme ved CFS/ME (44-46). Det trengs imidlertid flere studier før man kan konkludere sikkert.

Angst og depresjon forekommer relativt hyppig både hos barn og voksne med CFS/ME, og psykiske lidelser kan synes å være disponerende faktorer for utvikling av CFS/ME (47-49). CFS/ME regnes imidlertid ikke som en psykisk lidelse, og skiller seg klart symptomatisk fra for eksempel depresjon (50).

\section{Vedlikeholdende faktorer}

Det er usikkert hva som opprettholder sykdomsbildet ved CFS/ME etter at den utløsende årsaken, som for eksempel infeksjoner, er behandlet. Flere studier har undersøkt hvorvidt pasienter med CFS/ME har kroniske infeksjoner, men foreløpig er det ikke entydige svar (51-53). Vedvarende autonom dysregulering kan også være med på å opprettholde tilstanden (31).

Kroniske sykdommer påvirker psykisk helse. Psykologiske forhold som forekomst av depresjon, og hvordan den enkelte takler å være syk over lengre tid, med eventuell samtidig angst for fremtiden, antas å påvirke sykdomsforløpet ${ }^{(54-58)}$. Det er essensielt at pasienten kartlegges grundig før en bestemmer hvilke hjelpetiltak som skal tilbys ${ }^{(59)}$. Se for øvrig kapittel 3.

\section{Forløp}

Forløpet av CSF/ME kan arte seg svært forskjellig og gi ulik grad av funksjonssvikt. De aller sykeste blir sengeliggende og pleietrengende i lengre perioder. Andel og antallet av de aller sykeste er ikke kjent, men gruppen utgjør en mindre andel av total forekomst. Hos enkelte pasienter varer sykdommen under to år, mens for andre blir dette en langvarig tilstand (60,61). En studie som fulgte voksne pasienter med CFS/ME over 25 år, viste at flertallet ikke lenger fylte kriteriene for CFS/ME ved studieslutt, men de hadde fortsatt betydelig dårligere helse enn friske kontroller og kom ikke tilbake til det funksjonsnivået de hadde før de ble syke (62). Kvinner er generelt alvorligere rammet enn menn (63). Høy alder, flere kroniske sykdommer, og psykiatriske tilleggsdiagnoser er risikofaktorer for et alvorligere sykdomsforløp (64,65). Pågående uheldig stress vil være forbundet med lengre sykdomsforløp (66).

Prognosen er bedre for barn og unge enn for voksne uansett alvorlighetsgrad (65,67). En meta-analyse av forløpsstudier, viste at 54-94 \% av barna med CFS/ME ble friske i løpet av oppfølgingsperioden (64). 


\subsection{Alvorlighetsgrad og funksjonsnivå}

CFS/ME innebærer ekstrem og til tider invalidiserende tretthet. På gruppenivå har pasienter med CFS/ME betydelig lavere funksjonsnivå enn pasienter med andre kroniske sykdommer som for eksempel kreft, depresjon eller revmatoid artritt (68,69), se figur 1 . De internasjonale konsensuskriteriene, ICC, fra august 2011 foreslår følgende inndeling (70):

- Ved mild grad er aktivitetsnivået redusert med minst 50 \% sammenlignet med før sykdomsdebut, dvs. man er selvhjulpen, kan for eksempel utføre lett husarbeid, enkelte vil være i stand til å jobbe, men dette går ofte på bekostning av fritidsaktiviteter og sosialt samvær, og man trenger hviledager og helger for å hente seg inn igjen.

- Ved moderat grad er man for det meste bundet til huset, dvs. at all aktivitet er sterkt redusert og man trenger ofte å sove noen timer på dagen.

- Ved alvorlig grad er man sengeliggende det meste av dagen, dvs. at de fleste bytter mellom seng og sofa og bare er i stand til å utføre lette aktiviteter som tannpuss og inntak av mat. Mange har alvorlige kognitive problemer, og de er ofte avhengig av rullestol.

- Ved svært alvorlig grad er man sengeliggende hele døgnet og pleietrengende, dvs. at man som regel har behov for hjelp til personlig hygiene og matinntak, er meget ømfintlig for sanseinntrykk, og enkelte vil ikke være i stand til å svelge mat og har derfor behov for sondeernæring.

Utmattelsen hos CFS/ME-pasienter svinger gjerne betydelig fra dag til dag. Dette kan skyldes overbelastning, men det er ikke alltid at man klarer å finne forklaringen på symptomsvingningene (71) (Se kap. 3.).

\section{Figur 1}

Figuren viser at kvinner og menn med CFS/ME oppgir dårligere livskvalitet og funksjonsnivå enn pasienter med kreft, depresjon og leddgikt (RA) samt friske personer. Resultatet bygger på spørreskjemaet SF-36.

\section{A Figure 1a-Comparison of SF-36v2TM in men with ME/CFS, other health conditions and healthy.}

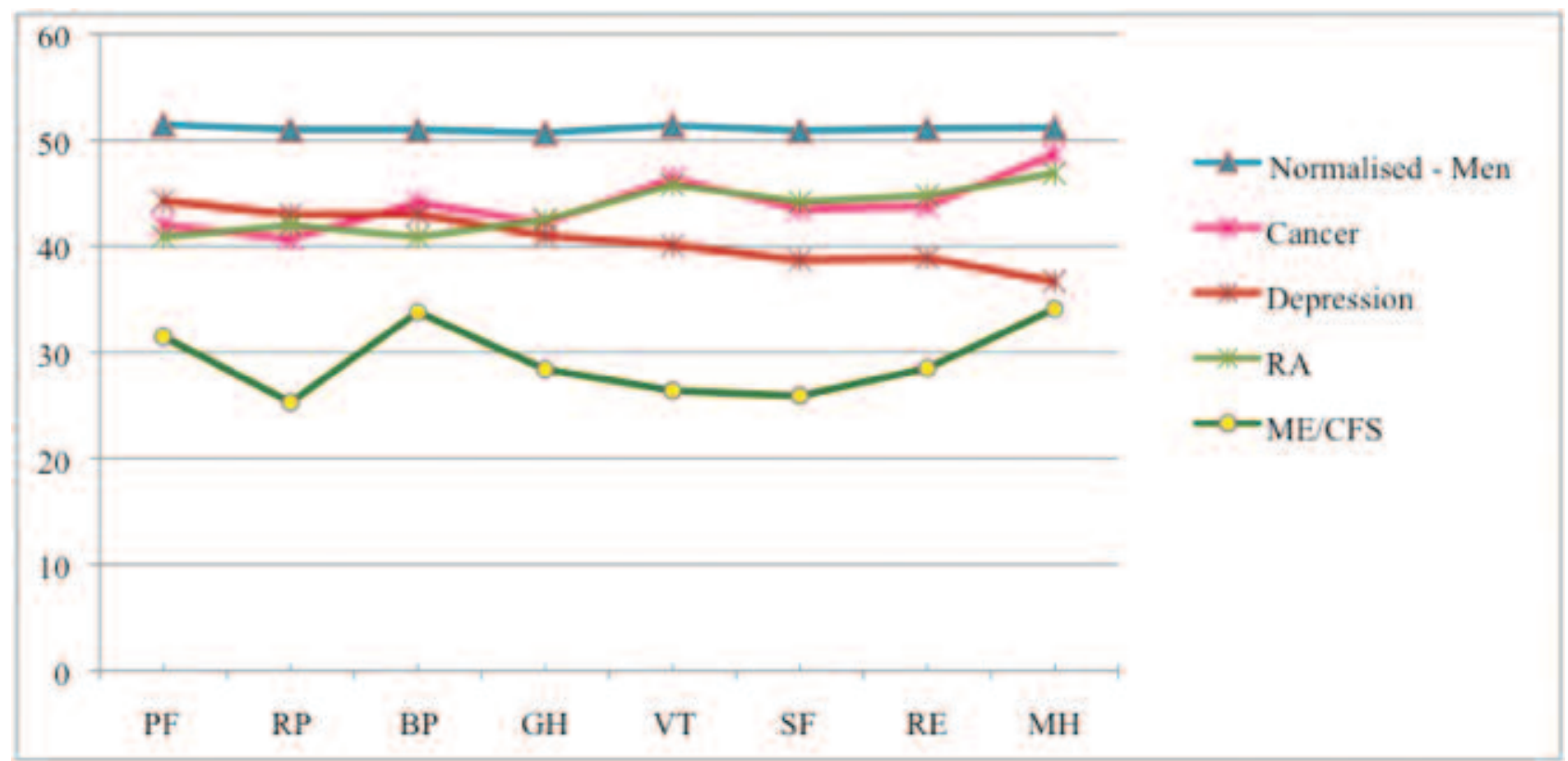


1.B Figure 1b-Comparison of SF-36v2TM in women with ME/CFS, other health conditions and healthy.

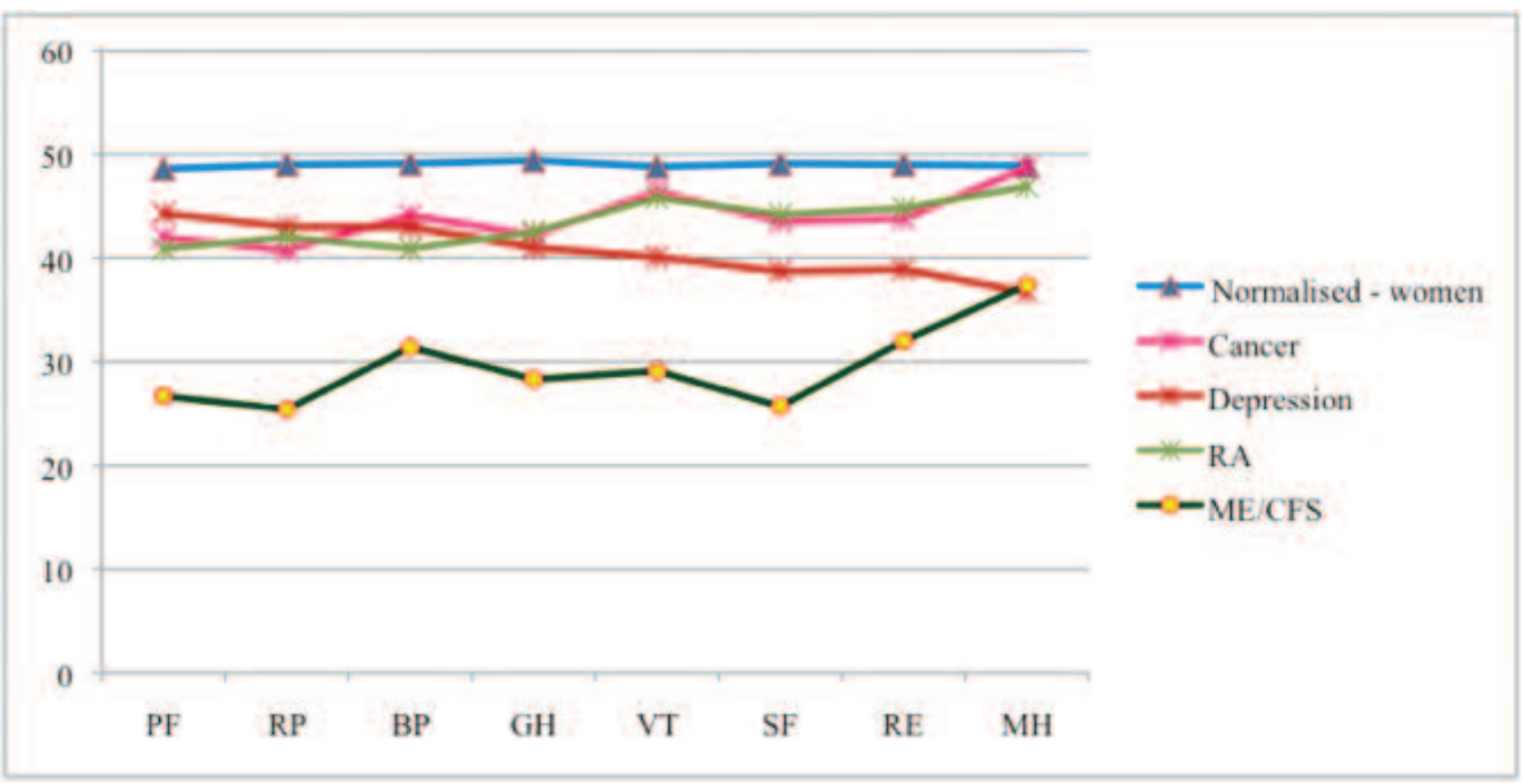

SF-36v2 skår hos menn og kvinner med CFS/ME, andre sykdommer og hos friske. RA - revmatoid artritt; PF - fysisk funksjonsnivå; RP - fysiske begrensninger i daglig aktivitet; BP - kroppslige smerter; GH - generell helse; VT - vitalitet; SF - sosialt funksjonsnivå; RE - hvordan mental helse gir redusert aktivitet i dagliglivet. $\mathrm{MH}$ - mental helse. Gjengitt med tillatelse fra forfatteren. (Nacul LC, Lacerda EM, Campion P et al. The functional status and well being of people with myalgic encephalomyelitis/chronic fatigue syndrome and their carers. BMC Public Health 2011: 11: 402)

\subsection{Forekomst}

Det er vanskelig å fastslå forekomsten av CFS/ME fordi inklusjonskriteriene i ulike studier har vært forskjellige (72). Studier fra USA og England anslår forekomst til 0,2-0,4 \% ved bruk av henholdsvis Canada- og Fukudakriteriene ${ }^{(5,73)}$. I USA er det påvist høyere forekomst blant minoriteter og i lavere sosioøkonomiske lag, men det er ukjent om dette er overførbart til Norge. Vi har ingen epidemiologiske studier av CFS/ME her i landet. Dersom vi antar at forekomsten i Norge ligner prevalensen fra de utenlandske studiene, finner vi et sted mellom 10 000-20 000 pasienter med CFS/ME av ulik alvorlighetsgrad i den norske befolkningen. Det er betydelig høyere forekomst av CFS/ME blant kvinner enn menn (5). Prevalensen av CFS/ME er lavere hos barn og ungdom enn hos voksne ${ }^{(74,75)}$.

\subsection{Forskning påCFS/ME}

Det forskes både nasjonalt og internasjonalt på årsaker til, sykdomsmekanismer bak, og behandling for CFS/ME. I Norge foregår flere forskningsprosjekter, blant annet:

\section{Helse Nord}

Nasjonalt forskningssenter innen komplementær og alternativ medisin (NAFKAM), driver et senter som lager registrer over eksepsjonelle forløp (RESF) ved alternative behandlinger. I et eksepsjonelt sykdomsforløp erfarer pasienten uvanlig positive eller uvanlig negative helseeffekter som knyttes til bruk av alternativ behandling. Helsedirektoratet ga i 2011 NAFKAM i oppdrag spesielt å gjennomgå alle registrerte pasientforløp mtp diagnosekriterier, samt gjøre en oppfølging for å kartlegge hvordan det har gått med pasientene en tid etter behandling med metoden «Lightning Process». Opplysningene som 
NAFKAM får gjennom journalgjennomgang og spørreskjemaer, skal analyseres ved NAFKAM og i tillegg gjøres tilgjengelige i anonymisert form for dem som, etter søknad, gis tilgang til å forske på CFS/MEpasienter i det omtalte registeret.

En studie finansiert av Norges forskningsråd, Quality, accessibility and coordination of health care in Norway for people with chronic illnesses - seen from the users' point of view.

\section{Helse Midt-Norge}

St. Olavs Hospital:

Behandlingsstudie på kognitiv atferdsterapi ved kronisk utmattelsessyndrom, denne er også utgangspunkt til flere pilotstudier, som «Cytokine levelse in patients diagnosed with CFS» m.fl.

Validering av et klassifiseringsverktøy for CFS/ME.

En utredningsstudie ved poliklinikken for å etterhvert kunne beskrive ulike variabler/informasjon som f. eks. demografi, grad av tretthet, utløsende årsak m.fl.

\section{Helse Sør-Øst}

Oslo Universitetssykehus:

NorCapital: Utprøving av legemiddelet klonidin hos ungdom med CFS/ME og kartlegging av underliggende sykdomsmekanismer.

Kardiopulmonal treningstesting (sykkeltest) og utmattelse etter anstrengelse ved CFS/ME.

Effekten av mestringskurs på symptomer og sykdomsutvikling ved CFS/ME.

Validering av et klassifiseringsverktøy for CFS/ME.

En tematisk forsknings-biobank og et register over CFS/ME-pasienter ble startet i februar 2012.

Helse Vest

Helse Fonna HF

En transdiagnostisk tilnærming til angst, depresjon og CFS/ME. Biologiske markører.

\section{Helse Stavanger HF}

En proteomisk tilnærming til mekanismer for kronisk tretthet.

Helse Bergen - Haukeland Universitetssykehus

En nasjonal, multisenterstudie med behandling med rituximab ved CFS/ME. Studien bygger på en pilotstudie publisert i $2011^{(27) .}$

Det er stilt spørsmål om studier det refereres til i veilederen er gjort på pasienter med CFS/ME eller andre pasienter med utmattelse. Det er uttrykt ønske om at det oppgis hvilke diagnosekriterier som er brukt i de forskjellige studiene.

En publikasjon fra Kunnskapssenteret (BMJ Open. 2014 Feb 7;4(2):e003973. doi: 10.1136/ bmjopen-2013-003973. Case definitions for chronic fatigue syndrome/myalgic encephalomyelitis (CFS/ME): a systematic review. Brurberg KG et al) konkluderer med at det 
ikke er belegg for å si at ett av diagnosekriteriene er bedre enn andre til å identifisere pasienter med spesifikk "kun organisk" sykdom. Siste året er det også kommet flere publikasjoner som viser at det ikke er biologiske forskjeller mellom de som tilfredsstiller strengere kriterier og de som ikke gjør det. (Brain Behav Immun. 2015 May;46:80-6. doi: 10.1016/j.bbi.2014.12.025. Plasma cytokine expression in adolescent chronic fatigue syndrome.

Wyller VB et al.; Acta Paediatr. 2015 May;104(5):498-503. doi: 10.1111/apa.12950. Study findings challenge the content validity of the Canadian Consensus Criteria for adolescent chronic fatigue syndrome. Asprusten TT et al) Det vurderes derfor dithen at det på nåværende tidspunkt ikke er behov for å spesifisere hvilke diagnosekriterier som er brukt i de forskjellige studiene. (Mai 2015) 


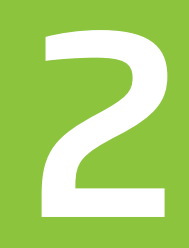

\section{Hvordan stilles diagnosen?}


CFS/ME-utredning består i å kartlegge pasientens sykehistorie (anamnese) og symptombilde, samt å utelukke differensialdiagnoser. Symptomene skal være nyoppståtte, og det skal foreligge en betydelig redusert funksjon.

\section{Diagnosen stilles ved hjelp av:}

1. Grundig sykehistorie, klinisk undersøkelse og supplerende undersøkelser

2. Utelukkelse av annen fysisk og psykisk sykdom som kan forklare symptombildet

3. Definerte diagnosekriterier (se punkt 2.3)

\subsection{Hvordan utrede og diagnostisere?}

Barn og unge anbefales å få utredning og diagnose stilt av spesialist i barnesykdommer. Barne- og ungdomspsykiatrisk poliklinikk/psykisk helsetjeneste for barn og unge anbefales involvert for kartlegging av differensialdiagnostikk, kormorbiditet og psykososial belastning. (se veileder for Barneog ungdomspsykiatri) http://legeforeningen.no/fagmed/norsk-barne--og-ungdomspsykiatriskforening/faglig-veileder-for-barne-og-ungdomsspsykiatri/

Utredningen og diagnostisering av voksne utføres av fastlegen, fortrinnsvis av spesialist i allmennmedisin (se kapittel 5). Ved uklare differensialdiagnostiske problemstillinger bør fastlege henvise til relevante spesialister for å komplettere utredningen, men dette er ikke nødvendig for at diagnosen CFS/ME stilles. Diagnosen er en eksklusjonsdiagnose, men med et karakteristisk sykdomsbilde. Diagnosen kan ikke alltid stilles selv om diagnosekriteriene er oppfylt da andre sykdommer og tilstander også kan gi CFS/ME lignende symptom.(mai 2015) Det er derfor viktig å utelukke andre tilstander som for eksempel cøliaki, hypo/ hyperthyreose, nevrologiske sykdommer, primære søvnforstyrrelser og psykiske lidelser. En må også huske på at pasienter med CFS/ME kan ha andre sykdommer i tillegg. Vurdering i forhold til differensialdiagnoser, kormorbiditet og avdekking av belastende faktorer er viktig både for å hindre feildiagnostikk og for å sikre riktig behandling. Det er også viktig å kartlegge pågående psykososiale belastninger som kan være med på å vedlikeholde og/eller forverre funksjonen. Klinisk erfaring tilsier at det bør gjøres en bred utredning når en mistenker CFS/ME, både for å hindre feildiagnostikk, men også for å trygge pasienten på at (andre) pågående sykdomsprosesser er utelukket.

En rekke tilstander har et overlappende symptombilde med CFS/ME. Eksempler på dette er fibromyalgi, irritabel tarm syndrom og smertesyndromer (76). Mange pasienter tilfredsstiller kriteriene for flere av disse tilstandene, og det diskuteres om de er forskjellig uttrykk for samme tilstand eller komorbide tilstander (77-79). Det har også vært diskutert om kronisk borreliose er en undergruppe av CFS/ME, eller om det er uttrykk for en og samme tilstand (80). Angst og depresjon er også vanlige komorbide tilstander (81).

Andre diagnoser ekskluderer heller ikke nødvendigvis CFS/ME-diagnosen, så sant de ikke kan forklare symptomene.

En grundig klinisk undersøkelse på bakgrunn av en omfattende anamnese/sykehistorie sett i relasjon til definerte diagnosekriterier er sentralt. Dersom utredende lege mistenker CFS/ME, tilsier klinisk erfaring at en bør sette av $1 \frac{1}{2} 2$ time til konsultasjonen; delvis for å få gjort en grundig anamnese, men også for å observere pasienten og endringer hos ham/henne over tid. En bør imidlertid være klar over at dette kan bli for lenge for pasienten, og at en må legge inn pauser underveis. I tillegg bør det foretas supplerende undersøkelser for å utelukke annen sykdom. Ved behov benyttes også andre faggrupper som for eksempel ergoterapeut, klinisk ernæringsfysiolog og fysioterapeut i utredningen. 


\section{Anbefalt supplerende utredning}

\section{Klinisk-kjemiske blodprøver:}

Hb, SR, hvite m diff. telling, trombocytter, jern, transferrin, transferrinmetning og transferrinreseptor, ferritin, Na, K, Ca, P, Mg, glukose, albumin, CRP, ALAT, ASAT, GT, Bilirubin ALP, LD, kreatinin, CK, vitamin B12, folat, Vit. D, fritt T4, TSH, kortisol.

\section{Immunologiske prøver:}

Immunglobuliner, IوG, و I و IA, total IgE, ANA-screening, revmatoid faktor, anti-transglutaminase antistoff.

\section{Mikrobiologiske undersøkelser:}

Serologi (vanlig serum/gelglass): EBV (Epstein-Barr virus), CMV(Cytomegalovirus), VZV (Varicella Zoster virus), HSV (Herpes simplex virus), HIV (voksne), Toxoplasma, Borrelia, Mykoplasma pneumonia*, Chlamydophila pneumonia*, Hepatitt B og C, Parvovirus B19, PCR (EDTA-glass): Humant herpesvirus 6 og ved positiv serologi: EBV, CMV, parvovirus B19.

*Evt bør det gjøres PCR i nasopharynxaspirat på disse mikrobene

\section{Urinprøve:}

Stiks

\section{Billeddiagnostikk:}

Hos barn og unge er røntgen thorax, ultralyd abdomen og MR caput obligatorisk, hos voksne må det utvises skjønn.

\section{Psykiatrisk:}

Semistrukturert intervju og/eller spørreskjema mhp komorbiditet og differensialdiagnostikk

\section{Psykososialt:}

Kartlegging av belastningsfaktorer mhp sårbarhet og mhp psykosomatiske tilstander, særlig viktig hos barn og unge.

\section{Elektrofysiologiske undersøkelser: \\ EEG hos barn og unge}

Følgende undersøkelser tas kun på spesielle indikasjoner: Spinalpunksjon, fecaltest, vippetest, søvnregistrering, 24-timers EKG, EEG (voksne), vurdering av psykolog/psykiater samt annen nevropsykologisk testing.

\subsection{Diagnosebetegnelser}

CFS/ME finnes ikke som egen diagnose verken i ICD 10 (hos lege i spesialisthelsetjenesten) eller ICPC (hos fastlege).

Flere ulike diagnostiske betegnelser med dels sammenfallende, dels avvikende innhold er i bruk i Norge i dag:

- Postviralt utmattelsessyndrom - ICD-10 G 93.3

Godartet myalgisk encefalomyelopati

- Nevrasteni ICD 10 F 48.0

Tretthetssyndrom 
- Utbrenthet - ICD 10 Z73.0

Allmenn utmattelse

- Uvelhet/tretthet - ICD10 R53 (asteni)

- Slapphet/tretthet - ICPC-2 A04

Inkluderer døsighet. Kronisk tretthet, postviral tretthet, tretthet, utmattelse, utslitthet

Dersom pasienten fyller noen av de omtalte kriteriesettene for CFS/ME (se under) anbefales G93.3 og ICPC-2 A04 brukt. Betydningen av differensialdiagnostikk understrekes. F48 vil kunne favne en videre gruppe pasienter der psykososial belastning er fremtredende, det samme vil Z73.0. Disse kan like fullt ha asteni som et hovedsymptom og vil kunne trenge mye av den samme behandlingstilnærmingen.

R53 bør kun benyttes før videre diagnostisk avklaring, eller der man ikke finner holdepunkter for verken G93.3, F48 eller Z73.0.

\subsection{Diagnostiske systemer og kriterier}

Det har vært benyttet ulike diagnostiske systemer og kriterier for å fastsette diagnosen. For mange diagnoser har kriteriene i årenes løp blitt innskjerpet for å finne « de riktige pasientene». Det har ofte medført at kriteriene har blitt mer kompliserte. For enkelte diagnoser har det da kommet spørreskjema og flytskjema som man kan bruke som hjelp. Slike finnes allerede for de kanadiske kriteriene og for fukudakriteriene. Nasjonalt kunnskapssenter for helsetjenester identifiserte i et notat fra 2011 mange ulike sett av diagnosekriterier for kronisk utmattelsessyndrom http://www.kunnskapssenteret.no/ Publikasjoner/Diagnosekriterier+for+kronisk+utmattelsessyndrom.12751.cms

De mest kjente er:

- CDC1988 kriterier (Holmes)

- Oxford 1991 kriterier (Sharpe)

- CDC1994 kriterier (Fukuda)

- Canadakriteriene 2003 (Carruthers)

- Pediatriske kriterier 2006 (Jason)

- NICE 2007 retningslinjekriterier

- Revidert utgave av Canadakriteriene 2010 (Jason)

I ettertid er det publisert ytterligere ett kriteriesett; Internasjonale konsensuskriterier (70). Det er foreløpig lite erfaring med bruken av disse, men kriteriene inkluderes i arbeidet som gjøres ved flere sentra hvor de sammenlikner ulike diagnosekriterier og validerer disse. Enkelte sentra har rapportert at ICC-kriteriene muligens er for strenge i forhold til diagnosen CFS/ME.

Flere har kritisert diagnosesettene for å mangle empirisk grunnlag. Kriteriesettene bygger på antakelsen at alle tilleggssymptomer er like viktige mtp diagnosesetting og at et visst antall symptomer skiller mellom de som har CFS/ME og ikke. Det er vist at disse antakelsene ikke holder (50,82). Det har derfor vært foreslått å bruke en enklere definisjon som kronisk utmattelse av ukjent årsak med betydelig redusert funksjonsnivå (50,82).

Selv om vi ikke vet om det ene diagnosesettet er bedre enn et annet, har vi valgt å beskrive og anbefale noen diagnosesett.

\subsection{Fukudakriteriene (CDC-kriteriene 1994)}

Fukudakriteriene (Fukuda et al. 1994) har fram til nå vært sentrale i forskning, og en stor andel forskningsmateriale er derfor basert på inklusjon ut fra disse kriteriene (83). 
Her brukes betegnelsen kronisk utmattelsessyndrom (Chronic Fatigue Syndrome).

Hovedkriterier (alle skal være oppfylt):

- Har pågått i 6 måneder eller mer

- Er vedvarende eller tilbakevendende

- Har en klar begynnelse

- Reduserer aktivitetsdeltakelse

- Bedres ikke av hvile

- Ikke er et resultat av pågående anstrengelse

Tilleggskriterier (minst 4 skal være oppfylt):

- Svekket korttidshukommelse og/eller konsentrasjon som reduserer aktivitetsdeltakelse

- Sårhals

- Ømme lymfeknuter

- Muskelsmerter

- Smerter i flere ledd

- Nyoppstått hodepine

- Manglende følelse av å være uthvilt etter søvn

- Forverret sykdomsfølelse i minst 24 timer etter anstrengelse

\section{Eksklusjonskriterier:}

- En hvilken som helst pågående medisinsk tilstand som forårsaker kronisk utmattelse (eks. ubehandlet lavt stoffskifte, primære søvnforstyrrelser, medikamentbivirkninger)

- Tidligere diagnostiserte medisinske tilstander uten medisinsk forsvarlig dokumentert opphør og hvor tilstedeværelsen av tilstanden kan forklare den kroniske utmattelsen (eks. nylig behandlet kreft, kroniske tilfeller av hepatitt B og C, HIV)

- Tidligere eller nåværende diagnose av psykisk sykdom (alvorlige depressive lidelser med psykotiske eller melankolske trekk, bipolar lidelse, schizofreni, ulike vrangforestillinger, demens, anoreksia nervosa, bulimia nervosa)

- Alkohol eller stoffmisbruk fra og med de siste to år før den kroniske utmattelsen

- Sykelig overvekt

\subsection{Canadakriterier 2003}

De kanadiske kriteriene har vært i bruk blant annet på Haukeland Universitetssykehus, St Olavs Hospital, Universitetssykehuset i Nord-Norge og Oslo Universitetssykehus ME/CFS-senteret i flere år (84).

http://www.cfids-cab.org/cfs-inform/CFS.case.def/carruthers.etal03.pdf

Hovedkriterier (alle skal være oppfylt)

- Utmattelse (fysisk og psykisk) som reduserer aktivitetsnivået med 50 \% eller mer

- Anstrengelsesutløst sykdomsfølelse og/eller utmattelse med lang restitusjonstid (24 timer eller mer)

- Søvnforstyrrelser, forstyrret døgnrytme, problemer med innsoving, forstyrret søvnlengde og -mønster

- Smerte, muskel/leddsmerter, ofte migrerende, hodepine av ny karakter

\section{Tilleggskriterier}

- Nevrologiske/kognitive utfall. To eller flere av følgende symptomer

- Forvirret

- Svekket konsentrasjon og korttidshukommelse

- Desorientert

- Vansker med å bearbeide informasjon

- Problemer med å kategorisere informasjon og finne ord

- Sanseforstyrrelser 
- Minst ett symptom fra to av følgende kategorier

- Nevroendokrine utfall (forstyrret termostabilitet, intoleranse for ekstrem hete og kulde, markert vektendring, tap av adaptasjonsevne, forverring av symptomer ved stress/belastninger)

- Autonome utfall (blodtrykksfall, hjertebank, ørhet, ekstrem blekhet, kvalme og irritabel tarm, blæreforstyrrelser, skjelvinger, kortpustethet ved anstrengelser)

- Immunologiske utfall (ømme lymfeknuter, sår hals, influensafølelse, generell sykdomsfølelse, overfølsomhet for mat, medisiner og/eller kjemikalier)

- Sykdommen vedvarer i minst 6 måneder. Den har vanligvis en klar identifiserbar begynnelse, selv om den kan være gradvis. En foreløpig diagnose kan være mulig tidligere. Tre måneders sykdomsforløp er tilstrekkelig for å stille diagnosen hos barn.

- Det er et lite antall pasienter som ikke har smerter eller søvnproblemer, men ingen annen diagnose passer unntatt CFS/ME. Diagnosen CFS/ME kan overveies hvis denne pasientgruppen har fått kronisk utmattelse etter en infeksjon.

\section{Eksklusjonskriterier:}

Pågående sykdomsprosesser, inkludert primære psykiatriske lidelser og rusmisbruk, som kan forklare de fleste symptomene på utmattelse, primære søvnforstyrrelser, smerte og kognitive forstyrrelser, utelukker diagnosen kronisk utmattelsessyndrom.

\subsection{Pediatriske kriterier 2006 (Jason 2006) ${ }^{(85)}$}

- Klinisk vurdert, uforklarlig, vedvarende eller residiverende kronisk utmattelse i løpet av de siste tre måneder som:

- Ikke er et resultat av pågående anstrengelse

- Ikke lindres ved hvile

- Fører til en betydelig reduksjon i forhold til tidligere nivåer med hensyn til utdanning, sosiale og personlige aktiviteter

- Må ha vedvart eller gjenoppstått over en periode på minst tre måneder

- Følgende samtidige klassiske kronisk utmattelsessyndromsymptomer må ha vedvart eller residivert i løpet av de siste tre måneders sykdomsforløp (symptomene kan komme forut for den rapporterte starten på utmattelsen - alle må være oppfylt)):

- Anstrengelsesutløst sykdomsfølelse og/eller utmattelse. Ved hvilken som helst type aktivitet må det oppstå et tap av fysisk eller psykisk utholdenhet, rask/plutselig muskulær eller kognitiv utmattelse og en tendens til forverring av andre assosierte symptomer hos pasienten. Restitusjonen er vanligvis langsom, og tar ofte 24 timer eller mer

- Ikke-uthvilende søvn eller forstyrrelser i søvnkvalitet eller rytme. Kan inkludere økt søvnbehov (inkludert hyppige høneblunder/lurer), forstyrret søvn og/eller forandret døgnrytme

- Smerter (eller ubehag) som ofte er utbredt og vandrende av natur. Det må forekomme minst ett av følgende symptomer:

- Muskel- og/eller leddsmerter i et hvilket som helst ledd, men må forekommer i mer enn ett ledd og det må ikke være tegn på hevelser eller andre betennelsestegn i leddet.

- Magesmerter og/eller hodesmerter

- To eller flere kognitive manifestasjoner:

- Svekket hukommelse

- Problemer med å holde fokus

- Vansker med å finne riktige ord

- Glemmer ofte hva man ønsket å si

- Åndsfraværende 
- Langsom tankegang

- Problemer med å gjengi/huske informasjon

- Kan bare fokusere på en ting om gangen

- Problemer med å uttrykke tanker

- Problemer med å forstå informasjon

- Mister ofte tråden i en tankerekke

- Nyoppståtte vansker med matematikk eller andre skolefag

- Minst ett symptom fra følgende to av de følgende tre kategorier:

- Autonome manifestasjoner (blodtrykksfall, økt hjertefrekvens, svimmelhet, forstyrret balanse, kortpustethet)

- Nevroendokrine utfall (feberfølelse og kalde ekstremiteter, unormal kroppstemperatur og tydelige døgnvariasjoner, svettetokter, intoleranse for hete og kulde, markert vektendring, forverring av symptomer ved stress/overbelastning)

- Immunologiske manifestasjoner (hyppig influensafølelse, sår eller irritert hals, stadige perioder med feber og hetetokter, ømme, men ikke spesielt hovne lymfeknuter, ny overfølsomhet for mat, lukt eller kjemikalier)

\section{Eksklusjonskriterier}

- Enhver pågående medisinsk tilstand som kan forklare tilstedeværelsen av kronisk utmattelse

- Noen pågående psykiatriske tilstander som kan forklare tilstedeværelsen av kronisk utmattelse (barneschizofreni, bipolar lidelse, pågående alkohol- eller stoffmisbruk, pågående anorexia nervosa eller bulimia nervosa, depressive lidelser)

\section{Ikke-ekskluderende tilstander:}

- Psykiske lidelser/tilstander som skolefobi, separasjonsangst, angstlidelser, somatoforme lidelser, depressive lidelser

- Andre tilstander som hovedsakelig defineres av symptomer som ikke kan bekreftes av diagnostiske laboratorietester (overfølsomhet for mat og/eller kjemikalier, fibromyalgi)

- Enhver tilstand hvor spesifikk behandling tilstrekkelig lindrer alle de tilhørende symptomer og hvor behandlingen er tilfredsstillende dokumentert

- Enhver tilstand som ble behandlet med en spesifikk terapi før utvikling av kronisk symptomatisk følgetilstand

- En hvilken som helst isolert og uforklart klinisk undersøkelse, samt laboratorietester eller billeddiagnostiske tester som er utilstrekkelig til å kunne indikere eller bekrefte tilstedeværelsen av en eksklusjonstilstand

Det anbefales at ett av disse settene med diagnosekriterier benyttes for å sette diagnosen CFS/ME (G93.3), og at det journalføres hvilket diagnosesett som er benyttet. Spesialister i allmennmedisin anbefales å kode dette som ICPC-2 A04 Det er utarbeidet skjema i forhold til de forskjellige kriteriesettene, se vedlegg 1,2 og 3. 


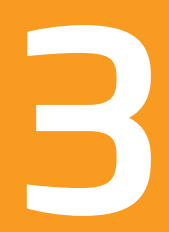

Behandling, rehabilitering og tilrettelegging 


\section{Det finnes i dag ingen dokumentert standard behandling som kan kurere CFS/ME. Det finnes behandlinger og strategier som kan lindre ubehagelige symptomer, bidra til konstruktiv mestring og bedre pasientenes funksjon og livskvalitet.}

Det mest karakteristiske ved CFS/ME er anstrengelsesutløst utmattelse og ulike andre symptomer. Slitenhet og utmattelse er i denne sammenheng to helt forskjellige ting. Utmattelse har store negative konsekvenser både for pasienten selv, for familien, og for samfunnet. Symptomene, og dermed også funksjonsnivå kan svinge fra dag til dag eller fra time til time. Mange erfarer at de ikke kan utføre samme mengde aktivitet en dag som en annen. Det kan derfor ikke forventes at en pasient alltid kan utføre samme aktivitet $\mathrm{i}$ dag som vedkommende greide i går, selv om forløpet er i bedring. Pasienter rapporterer at svingningene oftest utløses av overanstrengelser enten i form av fysisk, mental eller sosial aktivitet, praktiske gjøremål, overstimulering av sanser eller stress (71). Krav til aktivitet utover det pasienten selv opplever å mestre, kan ofte resultere i forverring av helsesituasjonen. Å avpasse aktivitetsnivået etter energimengden pasienten opplever å ha til enhver tid er viktig for å forebygge og redusere gjentatte ubehagelige, intense og langvarige forverringer. Ethvert tiltak som kan forhindre symptomforverringer vil ikke bare kunne stabilisere tilstanden, men også redusere ubehag og bedre pasientens livskvalitet.

Pasienter med kronisk sykdom har en rekke utfordringer som de kan trenge hjelp til. Det gjelder mestring av sykdomsrelaterte problem eller andre utfordringer som de har, eller som kommer i kjølvannet av sykdommen. Viktige områder som derfor også bør utredes og avklares kan være utdanning, skole eller jobb, forhold til familie, venner og øvrige nettverk eller praktiske og økonomiske problem. I tillegg er det viktig å få på plass døgn- og måltidsrytme, samt hjelp til stimulering av egenaktivitet. (Mai 2015) Symptom-behandling og ulike mestringsteknikker er nødvendig for pasienter med kronisk sykdom, det gjelder også pasienter med CFS/ME. I arbeidet med denne pasientgruppen er det nødvendig med kunnskap om behandling og oppfølging. Vanligvis motiveres og oppfordres pasienter til selv å ivareta sine gjøremål så sant de er i stand til å prøve. Hos personer med CFS/ME kreves for noen en annen tilnærming. Her kan det være aktuelt med aktivitetsavpasning og energiøkonomisering.

\section{1_Behandling-og-symptomlind ring.}

God klinisk praksis baserer seg på fagkunnskap, verdier, preferanser, ferdigheter og erfaring. Viktige bidrag til mer kunnskapsbasert praksis er tilfang av oppsummert forsknings- og erfaringsbasert kunnskap fra fag, klinikere og pasienter, faglig konsensus og faglige retningslinjer. Se også kapittel 7.

12011 lagde Kunnskapssenteret en sammenfatning av effekter av behandling, rehabilitering, pleie og omsorg for personer med kronisk utmattelsessyndrom. http://www.kunnskapssenteret.no/ Publikasjoner/Behandling+av+kronisk+utmattelsessyndrom+CFSME.12742.cms

- Deltagelse i arbeidsliv og skole: Kognitiv atferdsterapi gir muligens noe økning i arbeidslivsdeltakelse sammenlignet med standard behandling

- Utmattelse: Kognitiv atferdsterapi eller treningsbehandling gir trolig mindre utmattelse sammenlignet med henholdsvis standard behandling eller avspenning og tøyning. Det er begrenset med tilgjengelig dokumentasjon om effekt av farmakologisk behandling på grad av utmattelse.

- Livskvalitet: Kognitiv atferdsterapi gir muligens litt bedre livskvalitet sammenlignet med standard behandling eller annen psykoterapi. Det er usikkert om treningsbehandling sammenlignet med avspenning og/eller tøyning påvirker helserelatert livskvalitet. I beste fall kan treningsbehandling ha stor positiv effekt, i verste fall kan treningsbehandling ha liten eller ingen innvirkning på livskvalitet.

- Kvaliteten på dokumentasjonen er for mangelfull til at vi kan trekke konklusjoner om effekt av kosttilskudd og alternativ behandling.

- Det er behov for å oppsummere effekter av tiltak innen pleie og omsorg samt rehabilitering. Som mange har påpekt gir denne oppsummeringen uttrykk for både usikkerhet og marginale effekter. 
«Under utarbeidelsen av denne rapporten søkte vi utelukkende etter systematiske oversikter publisert fra og med 2005, og vi fant da ingen oversikter som omhandlet effekt av aktivitetsavpasning, avspenning, eller pleie- og omsorgstiltak. Det er mulig at det finnes systematiske oversikter om effekt av disse tiltakene publisert før 2005, men siden disse oversiktene etter alt å dømme vil være utdaterte er det behov for å søke etter primærstudier og lage systematiske oversikter dersom vi ønsker klare svar på effekt av disse tiltakene. Det samme gjelder effekt av tiltak blant de aller sykeste samt blant barn og unge med kronisk utmattelsessyndrom, for vi har ikke identifisert systematiske oversikter som søker å besvare spørsmål om effekt av tiltak blant disse pasientgruppene.»

\subsection{Begrepsforklaringer i forhold til ulike behandlings-/mestringstilbud}

Kognitiv atferdsterapi eller kognitiv terapi (KAT, Cognitive Behavioral Therapy - CBT) er en godt dokumentert behandlingsmetode for lettere psykiske lidelser ${ }^{(86)}$ og som hjelp til mestring av og symptomlindring ved ulike andre kroniske somatiske sykdommer (87, 88). Dette er bakgrunnen for at kognitiv terapi ofte fremheves i nasjonale behandlingsveiledere, også her i Norge. Begrepene kognitiv atferdsterapi og kognitiv terapi benyttes ofte synonymt. Kognitiv terapi er en behandling hvor tanker og særlig negative tankemønstre som er karakteristisk ved angst og depressive tilstander, blir gitt spesiell oppmerksomhet. Behandlingen dreier seg om bevisstgjøring av uheldige tankemønstre som kan bidra til å vedlikeholde problemene og symptomene (http://www.kognitiv.no/). Psykologiske faktorer som stress, angst og depresjon kan komme som en reaksjon på sykdommen, og påvirke både symptomforståelse og mestring på en negativ måte som dermed bidrar til å forsterke og forlenge utmattelse, smerte og andre symptomer. Kognitiv terapi som har vist seg å ha særlig god behandlingseffekt ved angst og depresjonstilstander, vil kunne være et nyttig supplement til medisinske og tverrfaglige behandlingsog mestringstiltak også for noen av pasientene med CFS/ME. En nyere randomisert kontrollert studie tyder på at ungdom kan ha positiv effekt av kognitiv atferdsterapi med tanke på både skolenærvær, grad av utmattelse og fysisk funksjon (89).

\section{Trening og fysisk aktivitet ${ }^{1}$}

Treningsbehandling eller treningsterapi (Exercise Therapy - ET) brukes om behandlingsformer der planlagt trening eller øvelser benyttes for å oppnå en spesifikk fysisk fremgang som økt styrke i svekkede muskler, økt fleksibilitet i ledd og bedret kardiovaskulær eller respiratorisk funksjon ${ }^{\left({ }^{90}\right)}$. Det finnes ulike former for treningsbehandling der forskjellen for eksempel kan ligge i aktivitetsform, intensitet eller frekvens.

Gradert treningsbehandling (GET) er en type treningsbehandling som tar utgangspunkt $i$ at terapeuten og pasienten definerer et realistisk mål for fysisk aktivitet per dag, basert på en kartlegging av pasientens utgangsstatus ( ${ }^{91}$. Aktivitetsnivået økes deretter gradvis, først med fokus på frekvens, deretter varighet og intensitet. I prinsippet omfatter treningen alle former for aktivitet, men ofte benyttes dagligdagse aktiviteter som gange. Det er viktig å unngå overbelastning, og derfor kan det være aktuelt å definere et intervall som pulsen skal holde seg innenfor under aktivitetsutøvelsen (91).

Tilpasset treningsbehandling er en form for gradert treningsbehandling som vektlegger et opplegg som er individuelt tilpasset til den enkelte pasient (www.cfstreningsbehandling.no). Her kombineres aktivitetsavpasning med en plan for individualisert opptrapping av fysisk aktivitet basert på stabilisering og opptrapping, herunder en betryggende strategi for håndtering av eventuelle tilbakefall (92).

\section{Aktivitets og energiregulering ${ }^{1}$}

Gradert aktivitetstilpasning (GAT) er et behandlings- og rehabiliteringsprinsipp basert på en individuelt tilpasset aktivitetsplan (93). Planen er mer helhetlig og skal inneholde alle aktiviteter og gjøremål, inkludert søvn og hvile, måltider, skole/arbeid og fritid. Aktivitetsnivået skal ikke oppleves belastende og må være 
tilstrekkelig gradert for å dempe oppmerksomheten om symptomer fra dag til dag (31). GAT innebærer en forsiktig og gradvis økning av alle aktiviteter og gir økt bevissthet over disponering av energi. Hvor raskt en slik økning skal skje må vurderes individuelt og ikke medføre forverring av symptomene.

Pacing eller adaptiv pacing terapi (APT) er en behandlingsform der pasienten læres opp til å regulere aktivitetsnivået etter dagsformen. Målsetningen er at man aldri skal overskride den individuelle tålegrensen (91). Pacing hjelper pasienter med CFS/ME å begrense anstrengelsesutløste symptomforverringer og er derfor godt egnet for pasienter som holder seg på eller nær sitt maksimale funksjonsnivå (94).

Energy Envelope Theory (EET) har hovedfokus på balansen mellom opplevd og brukt energi og har som utgangspunkt at hver person til enhver tid har en viss mengde energi til rådighet. Ved å bruke bare sin tilgjengelige energi vil personen kunne holde seg innenfor sin egen «energikonvolutt» og dermed hindre både over- og underforbruk ${ }^{(95)}$.

Både EET og pacing retter seg mer direkte inn mot forebygging av anstrengelsesutløste symptomer og ser ut til å kunne bidra til stabilisering av sykdommen, økt funksjon og forebygging av symptomforverringer (94-96). Begge tilnærmingene vil kunne egne seg som del av et individualisert, tverrfaglig mestringsopplegg- eller et rehabiliteringsprogram.

Det finnes mange enkeltstudier som viser at de nevnte tilnærmingene har effekt. PACE-trial er en nyere og mye omtalt randomisert kontrollert studie hvor voksne pasienter med CFS/ME ble tilfeldig fordelt i ulike grupper som mottok enten kognitiv atferdsterapi, gradert treningsterapi, pacing eller konsultasjoner med en spesialist, for så å sammenligne effekten av dem. Kognitiv atferdsterapi og GET viste seg å være mer effektive med hensyn til både å redusere utmattelse og å øke fysisk funksjonsnivå enn pacing eller spesialistkonsultasjoner alene (91). Det er kommet mange innvendinger mot denne undersøkelsen. Kritikken har blant annet handlet om at kognitiv atferdsterapi og GET kun ga marginalt bedre selvrapportert funksjonsnivå og at daglig aktivitetsnivå etter behandling ikke ble målt. «Number Needed to treat» (NNT) var sju, hvilket betyr at seks av syv ikke vil ha særlig effekt av kognitiv atferdsterapi sammenlignet med spesialistoppfølging av lege. Studien viste også at omfattende behandling med kognitiv terapi etter et år ikke ga noen effekt på økt deltagelse i arbeidslivet eller mottatte trygdeytelser ${ }^{(97,4) \text {. }}$

\subsection{Metoden bør tilpasses pasienten}

Det kan være frustrerende for behandlere og alle berørte at forskningen ikke kan gi klare og entydige resultater. Pasienter med CFS/ME er forskjellig med hensyn til symptomkarakteristika, behov og preferanser for hjelp. Det kan innebære at en metode som passer for en pasient ikke nødvendigvis passer for en annen, eller at flere tilnærminger vil kunne passe, men på ulike tidspunkt. For eksempel kan det være slik at en pasient med CFS/ME som i tillegg også er deprimert, redd, bekymret og preget av negative tankemønstre kan ha mest nytte av en kognitiv terapeutisk tilnærming i sin mestring. En pasient med en mer ustabil sykdom - med hyppige og intense symptomsvingninger vil først og fremst ha behov for hjelp til å stabilisere sine symptomer og sin tilstand. Da kan EET eller pacing være de beste alternativene. $\mathrm{Er}$ pasienten i tillegg deprimert eller har andre utfordringer av mer psykososial karakter kan KAT og andre psykologiske eller tverrfaglige tilnærminger være aktuelle. GET som har mest fokus på fysisk trening og opptrapping kan egne seg bedre for pasienter med et mer stabilt symptombilde, et høyere energinivå, mindre alvorlig grad av sykdommen og som selv ønsker hjelp til fysisk mobilisering eller opptrapping av sitt fysiske aktivitetsnivå. GAT som er en mer strukturert metode vil kunne egne seg bedre for pasienter som trenger hjelp utenfra i form av tydelige og faste rammer, enten det handler om sosiale eller fysiske aktiviteter. Spesielt barn og unge vil kunne nyttiggjøre seg GAT som et ledd i bevisstgjøring i bruk av energi. De har i større grad enn voksne behov for forutsigbarhet og de rammene en aktivitetsplan kan gi. 
Hva som egner seg best for den enkelte pasient bør være basert på pasientens spesifikke tilstand, utfordringer og preferanser. En kombinasjon av de ulike tilnærmingene vil noen ganger kunne være det beste. Dette er noe som bør utredes og avklares i et nært samarbeid mellom den enkelte pasient og behandler.

\subsection{Medikamentell og ikke-medikamentell symptomlindring}

Det er ikke publisert forskning på behandling av pasienter med alvorlig til svært alvorlig grad av CFS/ME, men det er skrevet kasuistikker som kan være nyttige (98). Det er kjent at pasienter med CFS/ME bruker mange ulike former for alternativ behandling eller mestringsteknikker. De rapporterer i varierende grad å ha effekt. Også blant helsepersonell eksperimenteres det med ulike former for symptomlindrende medikamenter. Det mangler fortsatt forskning og god dokumentasjon på effekten slike medikamenter og tiltak har på pasienter med CFS/ME på kort og lang sikt. Kunnskap om erfaringer fra pasienter og helsepersonell vil likevel omtales i det følgende:

Symptomlindring bør vurderes ved f. eks smerter og søvnproblemer. Det er imidlertid viktig å være klar over at noen pasienter opplever bivirkninger av medikamentell behandling. På grunn av økt følsomhet for blant annet virkestoffer viser tilbakemeldinger fra pasientene at det kan være viktig å fortsette med den typen medisin som er påbegynt fremfor å gå over til synonympreparater (se informasjon om byttbare legemidler for helsepersonell - Statens legemiddelverk). ${ }^{2}$ Tilbakemelding fra pasienter viser også at det kan være nyttig å begynne med doser som er langt under forventet virkedosedose for å la kroppen vende seg til medisinen, for deretter gradvis å øke dosen til minste virkedose. Denne prosessen kan gjerne ta flere uker.

Overfølsomhet kan gjelde for sanseinntrykk som lyd og lys, men også berøring. Skjermende tiltak kan for noen pasienter være nødvendig i perioder. Fullstendig skjerming mot støy som er aktuelt for svært få, kan være en stor utfordring å få til i praksis. Mørke rom gjør stell av pasienten vanskelig. Mange vil ha det best med en jevn, forholdsvis høy temperatur, noe som gjør utlufting problematisk. Samtidig er det rapportert at uhensiktsmessig skjerming av barn og unge kan virke sensitiverende på sikt og forverre/vedlikeholde tilstanden.

Erfaringsmessig opplever en del pasienter med CFS/ME at de har det bedre med et kosthold som gir lite svingninger i blodsukkeret. Små og hyppige måltider er ofte løsningen. Fordøyelsesplager er utbredt, men kan ofte lindres ved justering av kostholdet.

Smerte. Adekvat smertelindring er svært viktig, spesielt hos pasienter med utbredte, alvorlige smerter. Hittil har man ikke hatt spesifiserte behandlingsprotokoller for smertelindring ved CFS/ME. Perifere muskel-skjelett-faktorer ser ut til å spille liten rolle for smerter ved CFS/ME (99). Studier tyder på at smerter ved CFS/ME i stor grad skyldes sentral sensitisering (overfølsomhet for ulike stimuli i sentralnervesystemet). Informasjon til pasienten om smertemekanismen er viktig for å unngå katastrofetenkning og for å forklare pasienten hva som er årsaken til at hun/han har smerter (100). Dersom kognitiv terapi vurderes å være aktuelt, bør det legges opp med tanke på å bedre mestring av smerter etter samme prinsipper som hos andre pasienter med kroniske smerter. Sannsynligvis har pasienter med mest smerter også behov for medikamentell smertelindring. En vil kunne forvente effekt av medikamenter som virker på andre kroniske smertetilstand med sentral sensitisering, men dessverre mangler det behandlingsstudier av smerter ved CFS/ME (99).

Søvn er et område hvor mange pasienter kan oppleve store utfordringer enten det er snakk om manglende og lite søvn eller at pasienten sover unormalt mye (101). Det er ikke uvanlig å ha problem med 
innsovning eller å ha hyppige oppvåkninger i løpet av natten. Lite søvn på natten kan føre til at pasienten tar det igjen på dagen og dermed kommer inn i en uheldig søvn/døgnrytme som de kan trenge hjelp til å endre.

Erfaring tilsier at pasientene kan ha utbytte av praktisering av god søvnhygiene i tillegg til bruk av ulike avspenningsteknikker eller lysbehandling. I følge praksisfeltet synes mange å ha god effekt av melatonintabletter i perioder.

Avspenning Ulike former for avspenning har vist seg å kunne redusere smerter, stress og angst og ha gunstig innvirkning på søvn hos pasienter med andre kroniske somatiske sykdommer. Det er forsket lite på denne typen strategier for CFS/ME pasienter. I Norge er det imidlertid gjennomført en RCT-studie (Randomized contol trials) som viste at en tilpasset Qigong behandling - som er en meditasjons- og avspenningsform - ga bedring i både fysisk funksjon og utmattelse hos pasienter med CFS/ME (102) Utenlandske studier og «case-reports» tyder også på positiv effekt av denne behandlingen (103-105).

Pasienterfaringer. En nyere brukerundersøkelse utført av Norges ME-forening rapporterer at for de hyppigst utprøvde tilbudene som aktivitetsavpasning, vitamintilskudd, meditasjon/avspenning og fysioterapi, opplevde mange av pasienten at de fikk bedring (www.me-foreningen.no). Et fåtall av pasientene hadde prøvd medikamentell behandling og av disse var det mange som opplevde bedring. To behandlingsformer ble vurdert å ha gitt betydelig forverring (Gradert trening/kondisjonstrening og Lightning Process), men også her var det svært få som hadde prøvd det. M.E. Nettverket i Norge oppsummerer pasientenes tilbakemeldinger på følgende måte: De fleste pasienter oppgir at de kan få et bedre liv når de har fått korrekt diagnose, aksepterer sykdommen, lærer seg gode mestringsstrategier for de utfordringene CFS/ME kan gi og at tilpasning av aktivitet er et positivt hjelpemiddel i hverdagen.

\section{Alternativ behandling}

Det finnes et utall av medikamentelle og ikke-medikamentelle behandlingstilbud som pasienter benytter seg av. Erfaringer fra pasienter og pårørende tilsier at disse hjelper i varierende grad. Når det gjelder medikamenter som har vært forsøkt i behandlingen av pasienter med CFS/ME, som for eksempel forskjellige typer antibiotika, antiviral behandling, kortison, immunglobuliner og lavdose naltrekson (LDN) foreligger det ikke dokumentert effekt av noen av disse, og de kan derfor heller ikke anbefales av helsemyndighetene. Generelt anbefales det at ikke-medikamentelle tiltak bør være prøvd ut før man forsøker med medikamentelle. Når en vurderer alternative behandlingsformer, er det viktig å vurdere seriøsiteten i behandlingstilbudet, eventuelle bivirkninger og de økonomiske kostnadene. Dersom pasienten i samråd med behandlende lege ønsker å prøve spesifikke tiltak, er det viktig at pasienten får tilstrekkelig informasjon i forhold til mulige positive og negative effekter, samt at slik behandling utføres av fagpersonell med kompetanse/kunnskap både innenfor terapiformen og CFS/ME. Særlig for pasienter med alvorlig til svært alvorlig grad av CFS/ME må derfor legen vurdere forholdet mellom potensiell nytteverdi og risiko av forskjellige behandlingsmetoder i forhold til den enkelte pasient.

Lærings- og mestringskurs: er en del av pasient- og pårørendeopplæringen. Kurs gis i alle helseregioner. Se sykehusenes egne hjemmesider for informasjon om tilbudet på Lærings og mestringssentrene.

Likemannsarbeid er definert til å være funksjonshemmedes egen omsorgsarena http://www.ffo.no/no/ Sidemeny/Aktuelt/Organisasjonsliv/Likemannsarbeid/. Det dreier seg om hjelp til selvhjelp til mennesker som er i samme situasjon som en selv. Dette kan gjelde både funksjonshemmede og pårørende. Likemannsarbeid skal gi funksjonshemmede og pårørende et annet tilbud og dekke et annet behov enn det, for eksempel, fagpersonell kan bidra med. Utgangspunktet er at den som har skoen på vet best hvor den trykker. Det finnes brukerorganisasjoner for personer med CFS/ME. Se kapittel 4.5 for kontaktinformasjon til brukerorganisasjonene. 


\subsection{Rehabilitering for pasienter med CFS/ME}

Da det i dag ikke finnes noen helbredende behandling for CFS/ME vil behandling i hovedsak bestå av bistand til pasienten for å oppnå best mulig funksjonsnivå og livskvalitet. CFS/ME påvirker funksjonsevnen generelt og funksjonsvurdering viser at sykdommen kan påvirke de fleste aspektene i pasientens liv: kroppsfunksjon, daglige gjøremål, skole/studier/utdanning, arbeid, familie, sosial deltagelse og fritids aktiviteter. Det finnes få studier om effekt av rehabilitering i denne pasientgruppen. Mange av de tiltakene som omtales her er basert på studier og erfaring med voksne pasienter med moderat til lettere grad av CFS/ME. Vi har derfor valgt å omtale barn og unge og pasienter med mer alvorlig grad av sykdommen $\mathrm{i}$ egne avsnitt.

Rehabilitering er tidsavgrensede, planlagte prosesser med klare mål og virkemidler. Flere aktører samarbeider om å gi nødvendig bistand til pasientens egen innsats for å oppnå best mulig funksjons- og mestringsevne, selvstendighet og deltagelse sosialt og i samfunnet. De fleste med CFS/ME vil ha behov for et rehabiliteringsforløp der langsiktige perspektiver blir kombinert med mer kortsiktige målsettinger og fleksible løsninger. Variasjoner i grad, stabilitet/ustabilitet og forløp i sykdommen vil være utslagsgivende i forhold til hvilke rehabiliteringstilbud pasientene kan ha utbytte av, alt fra kompleks rehabilitering i spesialisthelsetjenesten til lavterskeltilbud i kommunale frisklivssentraler.

\section{Overordnede prinsipper for rehabilitering av voksne personer med CFS/ ME:}

- Aktiv brukermedvirkning

- Informasjon og veiledning på bakgrunn av pasientens helsetilstand og funksjonsnivå, både hva som fungerer og hva som svikter

- Systematisk kartlegging og vurdering av individuelle rehabiliteringsbehov og preferanser.

- Evaluering og justeringer av tiltak avhengig av pasientens tilstand

- Støtte og samarbeid med pårørende

- Samhandling, opplæring og kommunikasjon for felles faglig forståelse for koordinerte tiltak

\section{Spesifikke rehabiliterings- og mestringstiltak}

Pasienter med CFS/ME har funksjonsnedsettelser som krever nytenkning når det gjelder utarbeidelse av tiltak innen rehabiliteringsfeltet. Balanse mellom aktivitet og hvile bør være et prioritert fokus. Innholdet forøvrig kan variere noe, men bør basere seg på og inneholde elementer fra dokumentert behandling og mestringsteknikker referert til tidligere. Som eksempel på mer spesifikt innhold er det ved Sørlandets Rehabiliteringssenter, http://www.sorlandets-rehab.no/, beskrevet:

- Kognitive mestringsteknikker

- Symptom-mestring ift utmattelse, søvn og smerte for å oppnå økt symptomkontroll

- Mestring av energibruk, bevisstgjøring rundt energibruk ift hva som gir og tapper for energi, døgnstruktur, planlegging av aktivitet og hvile

- Balanse mellom aktivitet og hvile

- Mestringsopplevelser som gir motivasjon, selvtillit

- Aktivitetsavpasning

- Avspenning

- Aktivitetstilpasning (i den grad det er nødvendig for å kunne gjennomføre en aktivitet uten at det gir ukontrollert symptom økning)

- Målsetning

Individuell tilpasning hvor det tas hensyn til sykdommens alvorlighetsgrad (se side 11), karakteristika, funksjon og pasientens egne erfaringer og preferanser, er uansett av stor betydning. 


\subsection{Funksjonskartlegging og vurdering}

For å kunne vurdere sykdommen, hvordan den arter seg og påvirker pasienten og hva pasienten trenger av hjelp er det nødvendig med en grundig kartlegging. Det anbefales å bruke ICF (Internasjonal klassifikasjon av funksjon, funksjonshemming og helse). Denne funksjonskartleggingen bør være utgangspunktet for planlegging av et rehabiliteringsforløp.

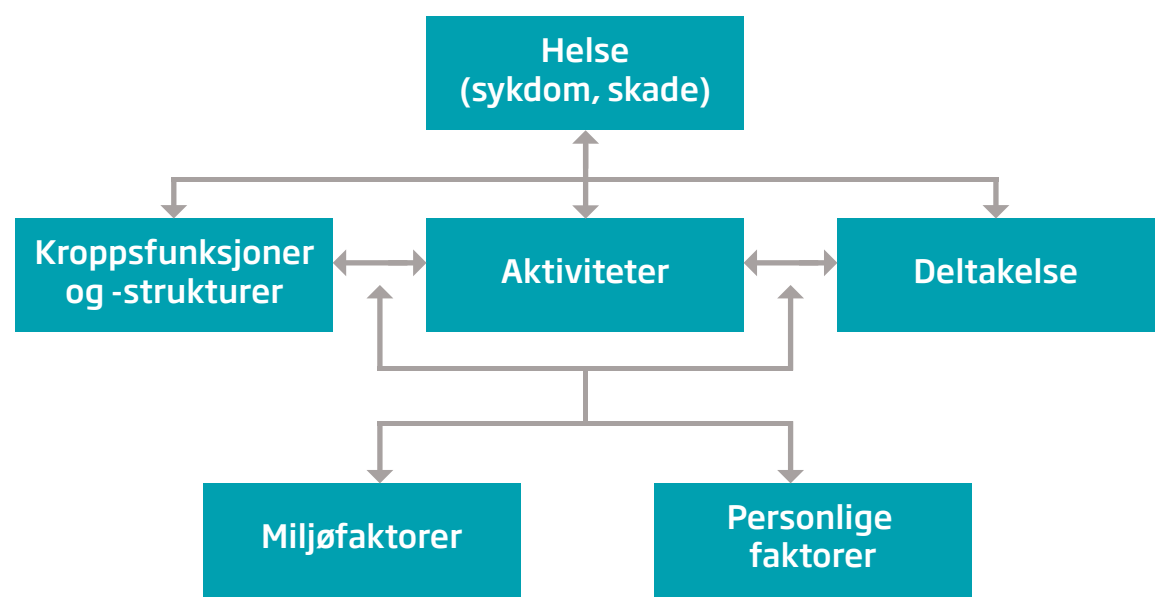

Figur 2. Vekselvirkninger mellom helsetilstander, helsefaktorer og helserelaterte faktorer

Funksjonsvurderingen bidrar til å identifisere relevante og/eller prioriterte problemområder, beskrive mål/delmål i et rehabiliteringsløp, vurdere og eventuelt igangsette tiltak, gi råd og anbefalinger. 
Boks 1. Konsekvenser av CFS/ME for helse og funksjon, kartlegging og tiltak i ICF (eksempel fra arbeidsgruppe i Helse Bergen): http://haukeland.no/omoss/avdelinger/fysmed/Sider/enhet.aspx

\begin{tabular}{|c|c|c|c|}
\hline ICF & Kartlegging av: & Verktøy (eksempler): & Tiltak (eksempler): \\
\hline $\begin{array}{l}\text { Kroppsfunksjon } \\
\text { og kroppens anatomi }\end{array}$ & $\begin{array}{l}\text { - Fatigue } \\
\text { - Kognitiv funksjon } \\
\text { - Fysisk funksjon } \\
\text { - Smerte } \\
\text { - Depresjon/ angst }\end{array}$ & $\begin{array}{l}\text { - } \text { FSS og FS } \\
\text { - PASAT, SDMT, SRT } \\
\text { - } 6 \text { min. gangtest, } \\
\text { SF-36 } \\
\text { - VAS } \\
\text { - HAD }\end{array}$ & $\begin{array}{l}\text { - Aktivitetstilpasning } \\
\text { - Tilrettelegging skole, studier } \\
\text { - Fysioterapi, grenser, hvile } \\
\text { og jobb } \\
\text { - Smertestillende } \\
\text { - Antidepressiva, kognitiv } \\
\text { terapi }\end{array}$ \\
\hline Aktivitet & $\begin{array}{l}\text { - Alle oppgaver og } \\
\text { handlinger i hverdagen } \\
\text { - i hjemmet } \\
\text { - i arbeidet } \\
\text { - i fritiden } \\
\text { - fysisk aktivitet }\end{array}$ & $\begin{array}{l}\text { - COPM } \\
\text { - Funksjonsskjema }\end{array}$ & $\begin{array}{l}\text { - Aktiv, handlingsorientert } \\
\text { mestringstrategi } \\
\text { - utvikle nye rutiner } \\
\text { - utvikle nye vaner } \\
\text { - forenkle og prioritere } \\
\text { mellom oppgaver } \\
\text { - funksjonsvurdering }\end{array}$ \\
\hline Deltagelse & $\begin{array}{l}\text { - Deltagelse i sosiale } \\
\text { sammenhenger, ulike } \\
\text { livssituasjoner } \\
\text { - familieliv } \\
\text { - fritidsaktiviteter } \\
\text { - organisasjonsliv } \\
\text { - arbeidsliv }\end{array}$ & $\begin{array}{l}\text { - Coping } \\
\text { - Funksjonsskjema } \\
\text { - WSAS } \\
\text { - WRP }\end{array}$ & $\begin{array}{l}\text { - Vektlegge både kortsiktige } \\
\text { mål og langsiktige perspektiv } \\
\text { - Delta på lærings/mestrings- } \\
\text { kurs } \\
\text { - Personlig koordinator/IP } \\
\text { - Brukermedvirkning } \\
\text { - Forsøke gradert sykemelding } \\
\text { - Funksjons-og arbeidsevne- } \\
\text { vurdering }\end{array}$ \\
\hline Miljø/omgivelser & $\begin{array}{l}\text { - Bosted } \\
\text { - Nærmiljø } \\
\text { - Samfunnets krav } \\
\text { og forventninger } \\
\text { - Arbeidslivets krav } \\
\text { - Personlig bakgrunn } \\
\text { (utdannelse, jobb, og } \\
\text { fritidsaktiviteter) }\end{array}$ & $\begin{array}{l}\text { - ISEL } \\
\text { - samtale med } \\
\text { sosionom/psykolog }\end{array}$ & $\begin{array}{l}\text { - Informere familie/venner } \\
\text { for at de skal forstå vanskene } \\
\text { og ta nødvendige hensyn } \\
\text { - Informasjon til arbeidsgiver } \\
\text { og studiested } \\
\text { - Vektlegge brukerperspektivet } \\
\text { - Gi informasjon og påvirke } \\
\text { holdninger } \\
\text { - Informere arbeidsgiver } \\
\text { - Læring og kompetanse- } \\
\text { henvisning, for å realisere mål }\end{array}$ \\
\hline
\end{tabular}

FSS ( Fatigue Severity Scale), FS (The Chalder Fatigue Scala), PASAT (Paced Auditory Serial Addition Test), SDMT (Single Digit Memory), SRT ( Selective Reminder Test), Short-Form General Health Survey (SF-36), VAS (Visual Analog Scale), HAD ( Hospital Anxiety and Depression Scale), COPM ( Canadian Occupational Performance Measure), WRP (Work Readiness Profile),WSAS (Work and Social Scale), ISEL( The Interpersonal Support Evaluation List)

Referanse: Holper L, : Characterization of functioning in multiple sclerosis using the ICF. J Neurol (2010) 257; 
Helse Bergen har erfaring med å bruke ICF som et godt og funksjonelt verktøy i rehabilitering med arbeid/ utdanning som mål. Særlig for å balansere forholdet mellom behandling, aktivitet og gjenopptakelse av utdanning og arbeid. Rapporten om metoden kan lastes ned.

\subsection{Rehabilitering med arbeid/utdanning som mål}

Mange i pasientgruppen er unge voksne. Behov for tilpasning av studiesituasjon og arbeidsliv er sentralt. Godt samarbeid mellom helsetjenesten og NAV er avgjørende for å oppnå gode rehabiliteringsplaner som tar hensyn til både medisinsk oppfølging, aktivitetstilpasning i dagliglivet og rehabiliteringstiltak med arbeid/utdanning som mål. Det bør legges til grunn en bred utredning for å kartlegge muligheter for skole/ utdanning/arbeid ved funksjonssvikt, for eksempel i samarbeid med Pedagogisk Psykologisk Tjeneste (PPT), NAV lokalt, NAV Arbeidsrådgivning (ARK), utdanningssted eller arbeidsgiver. Energinivået hos en CFS/ME pasienter varierer. Det kreves derfor kunnskap og innsikt i tilstanden både for pasienten og for skole eller arbeidsgiver for å kunne tilrettelegge best mulig. Mange pasienter vil ha nytte av en individuell plan, der tverrfaglige møter, tidligere kalt ansvarsgruppe, bestående av brukeren, helsepersonell, fagpersoner fra NAV, skole eller arbeidsliv møtes for å samordne målsettinger og tiltak.

\subsection{Barn, ungdom og unge voksne}

Både kunnskap og erfaring om CFS/ME tyder på at sykdommen arter seg forskjellig hos barn/unge og voksne. Det er begrenset med forskning, men en nyere gjennomgang av forskingslitteraturen kan tyde på at kognitiv atferdsterapi kan ha noe effekt for enkelte i denne gruppen (106). Barn og unge er i den livsfasen hvor det er størst vekst, læring og utvikling. Viktige forutsetninger for å møte praktiske og sosiale utfordringer og barrierer legges tidlig i barne- og ungdomsalder. Barn, ungdom og unge voksne med CFS/ME vil ha store utfordringer og trenger særlige tiltak for å ivareta utvikling og livskvalitet. Mange opplever sosial isolasjon. Derfor blir skole/arbeid og deltagelse i fritidsaktiviteter viktige arenaer for rehabilitering. Særlige tiltak gjelder spesielt i forhold til:

- Koordinering og forutsigbarhet av offentlige tjenester, også i overgangsfaser

- Tilrettelegge for sosial deltagelse i skole, fritid og arbeid

- Ivareta pårørende og familie

Også for barn og unge er det derfor svært viktig å ha et helhetlig og bio-psykososialt perspektiv på tilstanden.

Koordinerte tjenester: Erfaring i arbeid med barn og unge har vist at en tverrfaglig tilnærming tidlig i forløpet i samarbeid med barnet selv, pårørende og aktuelle fagpersoner, kan gi gode resultater. Individuell plan er et godt verktøy for å koordinere tjenester for pasienter/brukere med behov for tjenester fra flere aktører (les mer i kapittel 4 og 6). Overgangen fra ungdom til ung voksen er utfordrende, både for den det gjelder, familien og tjenestene. Fra barn til voksen skjer det en endring med hensyn til hvilke deler av tjenesteapparatet $\mathrm{i}$ kommune- og spesialisthelsetjenesten som skal bistå og følge opp ungdommene. Det er viktig å sikre gode overganger.

Skole/høyere utdanning: For barn og ungdom er skolen både en fag- og sosialiseringsarena. Mange med CFS/ME har en kognitiv utmattelse, i tillegg til den fysiske. Dette gir blant annet svikt i korttidsminnet, redusert evne til konsentrasjon og synsforstyrrelser. Disse utfallene fører til problemer med å lese og forstå tekst, og noen mister evnen til å gjennomføre enkle regnestykker. Mange opplever også belastninger ved å bli utsatt for mye støy, andre er plaget med ortostatisk intoleranse og har problemer med å stå eller sitte oppreist over lengre tid. Individuell aktivitetstilpasning med mål om å sikre balanse mellom skole og fritid i samarbeid med skole, barnet selv, pårørende og lege er sentralt i oppfølgingen. Hvis pasienten utsettes for press og stress kan det føre til at pasienten blir betydelig sykere, og ute av stand til å prestere en periode. Praktiske tilpasninger, som korte økter fremfor èn lang, skoletid når 
barnet/ungdommen føler seg best, fokus på fag barnet/ungdommen liker og mestrer, og tilpasset opplæring/spesialundervisning kan bidra til å gjennomføre skoleløpet til og med videregående skole. Behov for undervisning i hjemmet for den enkelte elev vil bero på en vurdering foretatt av PPT, evt. i samarbeid med lege eller andre sakkyndige og være i samsvar med reglene i opplæringsloven kap. 5. For andre kan prioritering av tilstedeværelse på skolen for å få dekket et sosialt behov være det viktigste.

Samarbeid mellom skolen og helsetjenesten, samt individuell tilrettelegging av undervisning, er nærmere omtalt i Helsedirektoratets kommende veileder i habilitering og opplæring av barn og unge med habiliteringsbehov (planlagt publisert høst 2014). Samarbeid mellom skole og helsetjeneste er særlig viktig. Det bør opprettes tverrfaglige grupper rundt barnet/ungdommen, og det bør utarbeides en aktivitetsplan. Planen må være individuelt tilpasset etter aktivitetsnivå (grad av energi) på grunnlag av barnets/ungdommens ønsker/interesse. Planen bør inneholde alle aktiviteter og gjøremål, som måltider, skole, fysisk aktivitet, søvn, hvile, tv/pc, plikter og fritid. Erfaringer fra praksisfeltet tyder på at det kan være hensiktsmessig at veileder/koordinator for planen kan være en utenfor familien, for eksempel ergoterapeut, fysioterapeut, helsesøster eller lærer. På skoler med flere ungdommer med tilsvarende problemer kan det være nyttig med samtalegrupper i regi av skolehelsetjenesten. For pasienter under høyere utdanning er det viktig å samarbeide med studiestedet, for eksempel gjennom studenthelsetjenesten og kommunale tjenester i studiekommunen.

Fritid: Fritidsaktiviteter og venner bidrar til å øke mestringsfølelsen og livskvaliteten. For barn, ungdom og unge voksne er fritidsarenaen viktig for sosial deltagelse og identitetsutvikling. Fritidsarenaen bør inkluderes i en individuell plan. Barn og unge med lettere og moderat grad kan ha nytte av fysisk aktivitet. Denne bør være lekpreget og gjerne foregå i gruppe, slik at det sosiale aspektet blir ivaretatt. Det er svært viktig med variasjon av aktiviteter, og det må være mulighet for individuell tilpasning underveis i aktiviteten. Eksempler på aktiviteter som av erfaring har vist seg å kunne være nyttige er kroppsbevissthet, avspenning eller bassengøvelser.

Arbeid: Mange ungdommer og unge voksne med CFS/ME står i fare for ikke å komme inn i arbeidslivet. For å lykkes i overgangen fra videregående skole til et fremtidig arbeidsliv er en planlagt og samordnet innsats fra helsetjenesten, utdanningsinstitusjonene og arbeids- og velferdsforvaltningen vesentlig for å sikre deltagelse i arbeidslivet.

Familieperspektiv: Omsorgen, støtten og oppdragelsen fra foreldre og nær familie er det som betyr mest for barns utvikling og livskvalitet, og er barnas største ressurs. Å ha et barn med CFS/ME innebærer for mange foreldre større grad av belastning, stress og usikkerhet rundt foreldrerollen enn når man har et barn som ikke har en kronisk sykdom. Veiledning av hele familien er viktig. De som ønsker det skal få bistand til å utforme individuell plan og det skal gis informasjon om rettigheter som følger med denne diagnosen (les mer om dette i kapittel 4).

\subsection{Oppfølging av pasienter med pleie- og omsorgsbehov basert på erfaringer og eksempler fra praksis}

Nasjonalt kunnskapssenter for helsetjenesten påpeker i sitt notat fra 2011 at det er behov for å opp summere effekter av tiltak innen pleie og omsorg. For pasienter med mer alvorlig symptombilde og store funksjonsnedsettelser kan noen av de nevnte tiltakene være aktuelle dersom de tilpasses den enkelte. I tillegg vil denne undergruppen - som er liten - av CFS/ME pasienter ha behov for mer spesialiserte hjelpetiltak.

De aller sykeste pasientene opplever et forverret symptombilde selv ved den aller minste fysiske, sosiale og/eller mentale aktivitet, som å snakke eller spise. Noen mener at man i denne situasjonen i størst mulig grad bør skjerme pasienten for alle belastninger og avvente en spontan bedring av situasjonen. Andre argumenterer for at disse pasienter bør oppfordres til å opprettholde et visst minimumsnivå av aktivitet, 
og at dette på lang sikt vil gi bedring, selv om symptombildet forsterkes på kort sikt. Den vitenskapelige litteraturen gir dessverre liten sikker kunnskap om disse vanskelige problemstillingene. Også her vil prinsippet om å unngå både for høyt og for lavt aktivitetsnivå gjelde.

Psykisk bistand: I et kvalitativt intervju med pasienter som tidligere hadde vært sengeliggende i fra 3 til 25 år, ble det å kjenne seg trygg, respektert og ha styring med tiltak trukket frem som viktige faktorer i deres bedringsprosess. http://www.helse-nord.no/ikke-synlige-artikler/cfs-me-erfaringskonferansepresentasjoner-article99116-30653.html

Å redusere unødvendig stress og bekymring kan være et viktig tiltak for disse pasientene. I andre samtaler med pasienter har det kommet frem at det å plutselig oppleve svært ubehagelige og omfattende symptomer og store fall i funksjonsnivå kan være skremmende. Noen kan trenge hjelp til å bearbeide dette underveis, eller i etterkant for å redusere eller forebygge stressreaksjoner og mer langvarig angst for sykdom og symptomer. Opplevelse av hva som medfører negativt stress er individuelt. De aller sykeste, som det ikke er mange av, vil ikke kunne gjennomføre ordinære behandlingssamtaler. Det er da viktig at behandler forholder seg og legger forholdene til rette på en slik måte at det gir mest mulig forutsigbarhet og dermed ro og trygghet for pasienten.

Praktisk bistand: Pasientgruppen kan ha behov for praktisk bistand knyttet til mange av dagliglivets gjøremål. Det kan være husarbeid, innkjøp og matlaging, sørge for tilrettelegging for matinntak hvor enkelte har ernæringssonde for å sikre tilstrekkelig næring, samt å hjelpe til med å fylle ut skjema og søknader. De sykeste har behov for tilrettelagt pleie, men i tillegg er det viktig med tilrettelegging i forhold til aktivitetsutførelse. Tilpasset bestikk, drikkeflasker/sugerør er noen eksempler på dette, men andre aktuelle hjelpemidler må vurderes, både i forhold til energiøkonomisering, som dusjstol, arbeidsstol, elektrisk rullestol/permobil eller annet, men også som forebyggende tiltak og hjelpemidler i forhold til kontrakturer og liggesår, eksempler her kan være sykeseng, toalettstol, sengebord m.fl. Det er vesentlig at denne pasientgruppen har et stabilt og forutsigbart tjenestetilbud som involverer færrest mulig tjenesteytere. Tjenesten må organiseres slik at pasienten opplever kontinuitet og trygghet.

Brukerstyrt personlig assistent: For enkelte brukere kan brukerstyrt personlig assistent (BPA) være en god løsning. BPA er en alternativ måte å organisere tjenesten praktisk bistand og opplæring der personen selv er arbeidsleder for $\sin (\mathrm{e})$ assistent(er). Innenfor det tildelte vedtaket bestemmer brukeren hva assistenten(e) skal bruke tiden til. Dersom pasienten er alvorlig rammet av CFS/ME, kan et slikt ansvar medføre forverring av tilstanden, og brukeren bør derfor kunne overføre ansvaret til andre, f. eks pårørende.

Hjemmetjenester: Praktisk og medisinsk hjelp fra hjemmetjenesten kan være et godt tilbud og forutsetter god organisering av tjenesten. Det er viktig at hjemmetjenesten har gode rutiner på utføring av prosedyrer helt ned på detaljnivå for å sikre trygghet for mest mulig lik omsorg og oppfølging fra hele personalgruppen. God intern kommunikasjon og personell som er trygge på oppgavene de skal utføre vil kunne redusere belastningen for pasientene som mottar bistand fra mange helsearbeidere. Det bør legges til rette for at pasienter med CFS/ME har få helsearbeidere i turnus å forholde seg til. Stadig nye fagpersoner som har mangelfulle kunnskaper og/eller som må orienteres om særtrekk ved CFS/ME eller dens konsekvenser, kan bidra til forverring av tilstanden.

Hjemmesykepleien må ha tett samarbeid med det øvrige helsepersonell i kommunen, spesialisthelsetjenesten, NAV og andre ved behov. De aktuelle yrkesgruppene må samarbeide på tvers av fagene for å få helhetlige løsninger som samsvarer med pasientens mål. Det er viktig at fastlegen deltar i tverrfaglige møter. I slike samarbeid kan individuell plan være et godt verktøy for samordning.

Fagteam for svært syke pasienter med langvarige behov: Tilbud fra hjemmesykepleien regnes som nødvendig helsehjelp. Pasientgrupper med alvorlig sykdom trenger et fleksibelt og tilrettelagt tilbud, der hjemmesykepleie gis sammen med praktisk bistand (se boks 2). Det vil være behov for spesialkompetanse hos tjenesteyter. I kommuner/bydeler med flere pasienter med CFS/ME anbefales det å ha et eget fagteam som jobber direkte med pasienter som har langvarige behov. Teamet bør kunne ivareta behovet for opp- 
følging av f.eks kreftpasienter, mennesker med ALS og MS, i tillegg til personer med CFS/ME. Dette kan bidra til å sikre nødvendig faglighet og kompetanse i hjelpetiltaket. Det er også nødvendig at personell som påtar seg slike arbeidsoppgaver sikres god oppfølging.

Boks 2. Eksempler på tilpasninger som kan benyttes ved pleie og omsorg for brukere med alvorlig grad av CFS/ ME.

På erfaringskonferanser i regi av Helsedirektoratet i 2011 ble det presentert en del eksempler på pleie og omsorg for pasienter med CFS/ME. Tilsvarende behandling var allerede i bruk i pleie og omsorg for en bruker med alvorlig grad av CFS/ME. Foredraget ble holdt av lederen for den aktuelle kommunens avdeling for hjemmebaserte tjenester, i samarbeid med brukerens pårørende. Eksemplene bygger på Sidsel Kreybergs 12 grunnregler.(107) Eksemplene som er vist i veilederen er omdiskutert. I innspillsrunden høsten 2014 uttrykte deler av helsetjenesten bekymring for at bruk av eksemplene kan fremkalle frykt hos de syke for å måtte være i aktivitet. Det ble også påpekt at det er skadelig å ligge passiv og urørlig over lang tid. Helsedirektoratet understreker at det ikke er anbefalt at pasienter tilbys passiviserende tiltak der det ikke er nødvendig. Dersom brukerne likevel opplever at det er behov for en slik tilrettelegging, forutsetter dette at det etableres en kontinuerlig, tett og god oppfølging fra fastlegen og primærhelsetjenestens side. Det er også viktig at tiltaket evalueres med tanke på effekt og for å forebygge komplikasjoner til inaktivitet. (Mai 2015)

1. Brukere med alvorlig grad av CFS/ME trenger forutsigbarhet $\mathrm{i}$ kontakten med hjelperen, og i forhold til hvordan hjelpen utføres. Detaljerte prosedyrer på alle dagliglivets aktiviteter som bruker trenger bistand til er hensiktsmessig for å sikre dette. Å benytte samme prosedyrer gir trygghet. Hvordan disse gjøremålene utføres er avtalt med brukeren. Det er viktig å legge inn nødvendige pauser. Nye ansikter, nyheter (gode eller dårlige), overraskelser, forflytninger og omstillinger av alle slag er unormalt krevende. Alt som er nytt eller uventet kan medføre akutt og langvarig energitap - også plutselige lyder, tilsnakk og bevegelser i synsfeltet. Den syke må derfor ha forutsigbarhet i det daglige og må få nødvendig forberedelsestid hvis noe går utenom planen.

2. Brukere med alvorlig grad av CFS/ME er ofte ømfintlige for lydinntrykk. Bruker kan ha behov for å benytte hjelpemidler som øreklokker for å redusere støyimpulser. Soverommet bør hos noen være lydisolert mot resten av leiligheten. Dette er hensiktsmessig fordi leiligheten da er tilrette-lagt og isolert slik at de ansatte kan utføre dagligdagse aktiviteter uten at dette medfører støy for brukeren. Brukeren kan tilkalle hjelper ved bruk av en ringeklokke. All kommunikasjon kan hos de alvorligst syke være energikrevende - det er viktig å vurdere fra gang til gang hva som er nød-vendig kommunikasjon i situasjonen. Spørsmål kan være svært energikrevende, benytt helst rene ja-/neispørsmål, og vær varsom med å stille nye spørsmål hvis du ikke får svar. Lyder som høye fottrinn kan være krevende, benytt gjerne skotøy med myke såler for å unngå lyd, unngå helst plastovertrekk.

3. Flere brukere opplever å være lysømfintlige. Det er da viktig med tiltak for å skjerme brukeren. Han/hun kan benytte øyemaske eller solbriller, og det kan være hensiktsmessig å bruke lysskjerming på vinduer og i dører.

4. Noen er ømfintlige for lukt, hjelpere bør da ikke benytte sterkt parfymerte kosmetiske produkter, eller klær som er vasket med skyllemiddel. Det er viktig å sørge for god utluftning.

5. Brukeren kan være ømfintlige for berøring, og erfaringsmessig er det best når det benyttes langsomme, rolige bevegelser. Brå bevegelser, bruk av muskelkraft eller trykk mot et underlag, kan gi store smerter og i enkelte tilfeller utløse langvarig nedsatt funksjon i den aktuelle kropps delen. Reaksjonen kan komme forsinket.

6. Det er viktig å sørge for jevn temperatur i rommene der bruker oppholder seg. Kulde gir ubehag og kan nedsette funksjonsnivået. Mange er også følsomme for overoppheting. Vær obs på viktigheten av avlastning for trykk fra dyner og tepper når bruker er sengeliggende over tid. 
7. Toalettbesøk er ofte en stor påkjenning og kan kreve lang restitusjonstid. Bruk av bekken kan være hensiktsmessig for de som er sengeliggende.

8. Regelmessige måltider, gjerne ca fire timer mellom hvert måltid. Matintoleranse opptrer ofte ved CFS/ME, og kan variere betydelig i sykdommens løp. Varier kosten i samråd med brukeren, og vær

Iydhør på hvilken mat brukeren ønsker seg. Måltidene kan være et av dagens høydepunkt. Sondeernæring er nødvendig for enkelte av de alvorligste syke. Matinntak kan gi forbigående generelt nedsatt funksjon. For å spare energi er det for noen nødvendig å ha absolutt ro under og etter måltider.

9. Mange alvorlig syke CFS/ME pasienter opplever en unormal stor tørstefølelse, et behov for å drikke veldig mye mer enn før sykdommen debuterte. Vann må alltid være tilgjengelig. Noen av de sykeste trenger hjelp for å klare å dekke det daglige væskebehovet.

10. Personer med forkjølelse eller annen smittebærende sykdom bør ikke være i kontakt med brukere med CFS/ ME. Ved mistanke om slik sykdom, eller hoste, anbefales det å bruke munnbind. Særlig fokus på håndhygiene er nødvendig da CFS/ME-pasienter kan ha redusert infeksjons-forsvar. Selv en tilsynelatende enkel infeksjon kan utløse alvorlig og langvarig forverring.

\section{Botilbud}

Det er viktig med individuelle tilpasninger til pasienter med CFS/ME. Boligene må i enkelte tilfeller tilrettelegges for å ta hensyn til behovet for skjerming av lyd og lys. Valget kan stå mellom å utbedre den boligen pasienten bor i, eller å flytte til en mer egnet bolig. Ergoterapeut bistår i arbeidet med tilretteleggingen. Alvorlig syke kan ikke alltid bo alene eller hos pårørende. Enkelte kommuner har tilbud om bolig med service til de alvorligst syke, boligene kan da være utbedret med tanke på bl.a. lydisolering. Sykehjem er en boform som kommunene plikter å ha for å gi heldøgns tjeneste til de som trenger det. Det er et mål at ingen brukere under 50 år skal bo i alders- eller sykehjem, hvis de ikke selv ønsker det. Det kan ta tid å finne et passende botilbud.

\section{Individuelle rehabiliteringsprosesser}

Effektive koordinerte tiltak for personer med diagnosen CFS/ME må være individuelle og preget av bred tverrfaglig kompetanse. Når en bruker funksjonsvurderingen som et utgangspunkt for rehabiliteringsprosessen, er det viktig å ta i betraktning det en vet om tilstanden som langvarig, variasjonen i symptomintensiteten og at forskjellige pasienter har forskjellig forløp og individuelle mål. Rehabiliteringsbehovene kan forandre seg i løpet av rehabiliteringsprosessen. Prioriterte områder kan variere avhengig av sykdommens alvorlighetsgrad, symptomspekter og intensitet, livsfasen pasienten befinner seg i, samt forandringer oppnådd underveis i rehabiliteringsforløpet. Det er derfor nødvendig å evaluere forløpet underveis i prosessen og eventuelt aktualisere eller justere mål og tiltak.

\subsection{Utfordringer for helsepersonell}

Det kan være både faglig og personlig utfordrende å arbeide med CFS/ME pasienter som over langt tid ikke viser tegn til bedring, eller klarer å gi respons. For å ivareta personalet bør det derfor legges til rette for veiledning som kan hjelpe helsepersonell til å bearbeide og forholde seg til faglige og menneskelige, samt etiske utfordringer. Det er også nødvendig med tilstrekkelig personale som gir mulighet for avlastning og varierte arbeidsoppgaver, samt at personale får mulighet til å sette av tilstrekkelig tid slik at negativt stress ikke påføres pasienten i forbindelse med hjelpetiltakene.

Helsepersonell er en viktig ressurs for pasientene. Det er ikke alltid like lett å skulle forholde seg til en pasientgruppe hvor kunnskapen knyttet til både årsak og behandling er uklar, manglende, sammensatt og med få entydige svar og løsninger. På tross av ulike oppfatninger om bakenforliggende forhold og løsninger på problemet er det av stor betydning for den enkelte pasient å bli forstått, tatt på alvor og møtt med respekt i den sårbare situasjonen de faktisk er $\mathrm{i}$. 


\section{4}

\section{Brukere og pårørende}

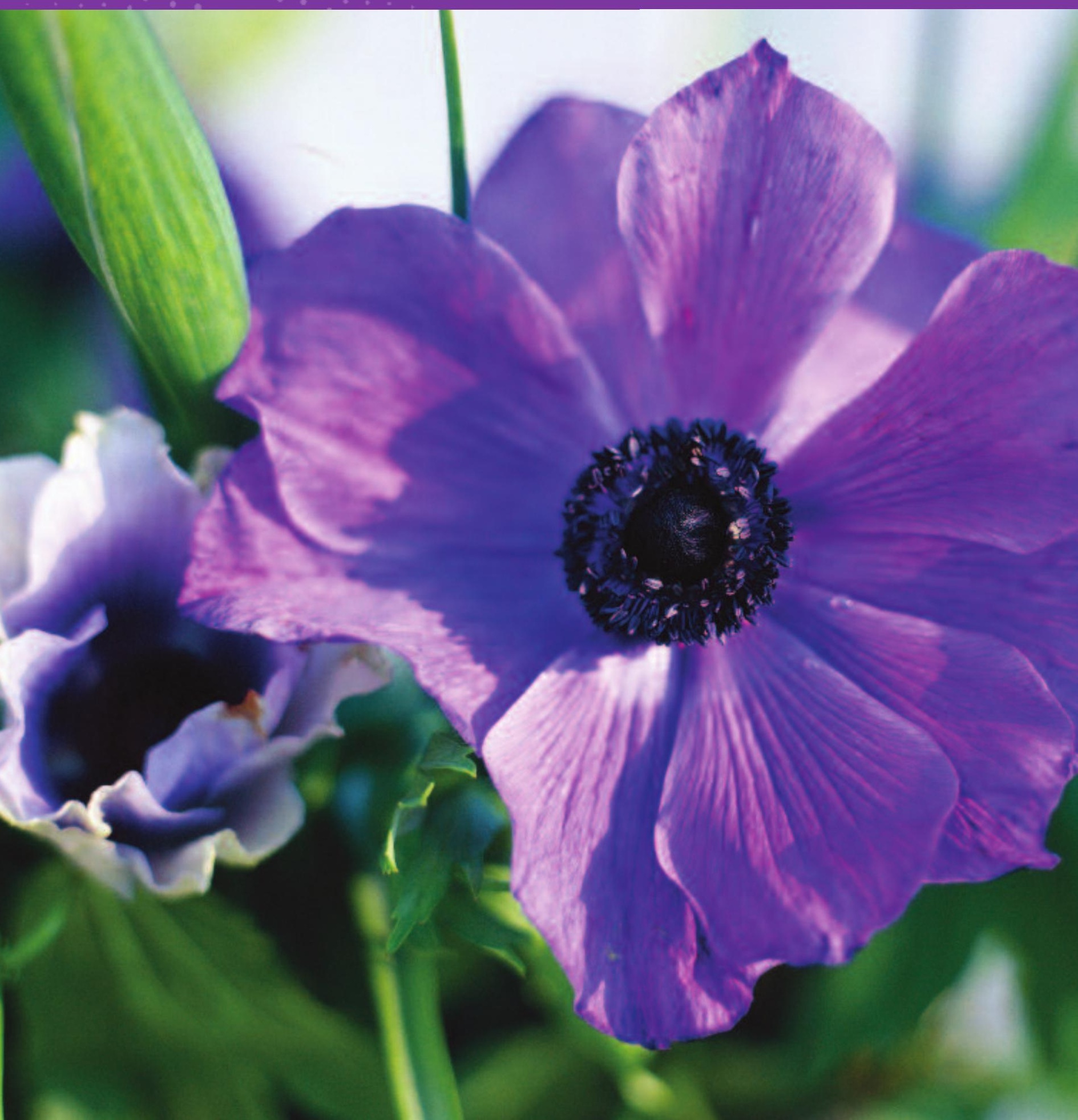




\subsection{Brukermedvirkning}

For alle mennesker er det viktig å ha styring på eget liv. Brukermedvirkning på individnivå er en rettighet, blant annet beskrevet i pasient- og brukerrettighetsloven. De beste løsningene, både for pasient og tjenesteyter, oppnås ved samarbeid. Brukermedvirkning i helse- og omsorgstjenesten gir kvalitativt bedre og mer relevante tjenester. Helsepersonells rolle som veileder er også viktig i forhold til brukermedvirkning. Veiledning må baseres på relevant erfaring og kunnskap og bidra til at brukere kan ta gode beslutninger på vegne av seg selv. Pasientens kompetanse om egen situasjon er avgjørende for at pasientens ressurser og mestringsevne skal bevares og styrkes, og for at han/hun skal beholde eller gjenvinne kontroll over eget liv.

Brukermedvirkning skjer både på system- og individnivå. Brukermedvirkning på systemnivå kan medvirke til utforming av tjenester som egner seg for pasientgruppen, og bidra til opplæring av tjenesteutøvere. På individnivå skjer brukermedvirkning ved at pasienten har rett til å medvirke ved valg mellom tilgjengelige og forsvarlige undersøkelses- og behandlingsmetoder. Medvirkningens form skal tilpasses den enkeltes evne til å gi og motta informasjon.

\subsection{Individuell plan}

Mange pasienter med CFS/ME vil ha god hjelp i å ta i bruk individuell plan som verktøy. Samhandling mellom pasient, pårørende og tjenesteyterne er helt avgjørende for et godt tjenestetilbud.

Alle som har behov for langvarige og koordinerte helse- og omsorgstjenester, har rett til å få utarbeidet en individuell plan. Retten er hjemlet i pasient- og brukerrettighetsloven $§ 2-5$. Brukerens behov og mål settes i sentrum uavhengig av tilbud og tilbydere av tjenester. Brukeren har rett til og skal oppfordres til å delta aktivt i å beskrive egne mål og behov for tjenester. Initiativet til å få laget en plan kan komme fra brukeren, pårørende eller helse- og omsorgstjenesten. Helse- og omsorgstjenesten har ansvaret for utarbeidelse. Koordinerende enhet for habilitering og rehabilitering $\mathrm{i}$ kommunen har det overordnede ansvaret for individuell plan, jf. helse- og omsorgstjenestelovens § 7-3.

Planen skal være et verktøy og en metode for samarbeid mellom bruker og de ulike tjenesteyterne. Planen skal evalueres og revideres jevnlig, særlig i overgangsfasene.

Formålet med individuell plan er at:

- den skal bidra til at brukeren får et helhetlig, koordinert og individuelt tilpasset tjenestetilbud

- det skal sikres at det til en hver tid er en tjenesteyter (koordinator) som har hovedansvaret for oppfølgingen av brukeren

- brukerens mål, ressurser og behov for tjenester skal avklares. Tiltakene som kan bidra til å dekke brukers behov skal koordineres

- den skal styrke samarbeidet mellom tjenesteyter og bruker og eventuelt pårørende, samt mellom etater innen et forvaltningsnivå eller på tvers av forvaltningsnivåene

Mer informasjon og tips om individuell plan finnes på www.helsenorge.no

\subsection{Koordinator}

For pasient og brukere med behov for langvarige og koordinerte tjenester skal kommunen tilby koordinator jf. helse og omsorgstjenesteloven § 7-2. Dette gjelder uavhengig av om pasienten eller brukeren ønsker individuell plan. Koordinator skal sikre samordning av tjenestetilbudet, og fremdrift i arbeidet med individuell plan. 


\subsection{Pårørende}

Pårørende vil inneha ulike roller både i forhold til den som er syk og i forhold til helsevesenet. De har ofte inngående kjennskap til den som er syk. Mange har omfattende omsorgsoppgaver, og de er en del av pasientens nærmiljø. Noen opptrer som pasientens representant, og mange pårørende har, som følge av vedvarende belastninger, selv behov for støtte og hjelp fra helsevesenet.

Helsedirektoratet har utgitt veilederen «Pårørende - en ressurs» Veileder om samarbeid med pårørende innen psykiske helsetjenester (IS-1512). Denne kan også være relevant for pårørende til pasienter med CFS/ME.

Pårørendes ulike roller:

- som kunnskapskilde

- som omsorgsgiver

- som del av pasientens nærmiljø

- som pasientens representant

- som ressurs

- med egne behov

Som kunnskapskilde: Pårørende har kunnskap som kan være viktig i både utredning, behandling og rehabilitering av den som er syk. De kjenner pasientens bakgrunn, vedkommende sine ressurser og symptomutforming. Pårørende vet også hvordan pasienten er når han eller hun ikke er syk, og har erfaring med hvordan ulike tiltak virker. De vil ofte ha kjennskap til pasientens synspunkter og kan bidra til å ta pasientens perspektiv; se fram i tid og bevare håpet.

Som omsorgsgiver: Pårørende er ofte pasientens nærmeste og viktigste omsorgspersoner. De bidrar ofte i daglige gjøremål og bistår med praktiske oppgaver. Noen ganger opptrer pårørende også som behandlers medhjelper $f$. eks. ved at de bistår pasienten i å følge opp anbefalt behandling. Når pårørende innehar rollen som omsorgsgiver bør oppgavene drøftes og klargjøres i samarbeid med behandlingsapparatet. Pårørende har ingen juridisk plikt til å ta omsorg for sine nærpersoner over 18 år. Det er en frivillig rolle, som forutsetter at pårørende får tilstrekkelig informasjon om pasientens helsetilstand og nødvendig støtte, avlastning, veiledning og rådgivning i forhold til oppgavene som skal utføres. Når det gjelder foreldre til barn/unge under 18 år, kan det ved (svært) alvorlig grad av CFS/ME innvilges pleiepenger. http://www.nav.no/rettskildene/Rundskriv/147958.cms

For andre kan det søkes hjelpestønad etter ulike satser, og for pasienter som har langvarige og omfattende pleie- og omsorgsbehov kan omsorgslønn for en av foreldrene også være aktuelt.

Som del av pasientens nærmiljø: Bekymringer hos pasienten kan øke faren for forverringer og tilbakefall. Erfaringen tilsier at når pasienter opplever at ektefelle/partner eller foreldre blir overbelastet, eller barna ikke får den oppfølgingen og oppmerksomheten som de trenger, kan dette føre til overanstrengelse hos pasienten.

Som pasientens representant: Som pasientens representant opptrer pårørende på vegne av pasienten. Rollen som representant kan følge av at foreldre representerer sine mindreårige barn, pårørende er oppnevnt som verge eller hjelpeverge, pasienten ikke har samtykkekompetanse, det foreligger skriftlig fullmakt fra pasienten eller at vedkommende ikke kan ivareta sine interesser.

Forholdene må da legges til rette slik at pårørende får nødvendig informasjon og mulighet til å ivareta pasientens interesser. Pårørende har i rollen som pasientens representant rett til informasjon, rett til å uttale seg om helsehjelp, rett til å påklage vedtak, samt rett til å medvirke ved gjennomføring av helsehjelp. 
Som ressurs: Pårørende med god kjennskap til pasientens sykdomstilstand kan også ha en rolle som motivator og støtte for pasienten. Viktige bidrag kan være å fokusere på gode, positive opplevelser i hverdagen og at pasienten kan ha god livskvalitet til tross for sykdomsutfordringer.

Med egne behov: Sykdommer som rammer den enkelte på så mange områder i livet vil ofte også påvirke familien og nære relasjoner. Det er derfor viktig at tjenesteapparatet ser og ivaretar ektefelle/partner, foreldre og barn i form av nødvendig praktisk hjelp og avlastning. Barn av pasienter må spesielt bli ivaretatt. Det må sørges for at de får informasjon, tilrettelagt for alder og modenhet.

Helsedirektoratet har utgitt rundskriv «Barn som pårørende» (IS-5/2010). Etter Helsepersonellovens §10a skal helsepersonell bidra til å ivareta det behovet for informasjon og nødvendig oppfølging som mindreårige barn av pasient med psykisk sykdom, rusmiddelavhengighet eller alvorlig somatisk sykdom eller skade kan ha som følge av forelderens tilstand. Når begrepet pårørende brukes om barn, må det ikke forstås slik at barnet skal ivareta foreldrenes behov.

Flere har erfaring med at pårørendegrupper er nyttig. Det å møte andre med lignende erfaring som en selv kan være til stor hjelp. Deltagelse i pårørendegruppe gir mulighet for å diskutere utfordringer og nyttige erfaringer, og mange opplever det som spesielt nyttig å få råd og tips fra «likemenn». Gruppene bør ledes av helsepersonell, og pårørendes rolle bør løftes som tema.

\subsection{Brukerorganisasjoner}

Det finnes brukerorganisasjoner for personer med CFS/ME:

- M.E. Nettverket i Norge (MENiN) http://menin.no/

- Norges ME-forening http://www.me-foreningen.no/

\subsection{Saksbehandling}

Kommunene har ansvaret for saksbehandling som munner ut i vedtak og tildeling av tjenester. Kommunen har opplysningsplikt om tilbud og rettigheter, og skal sørge for at alle får tilgang til tilpasset informasjon. Kommunens tilbud, og pasientens rettigheter, er store felt å sette seg inn i. Informasjonen må utformes og gis med utgangspunkt i pasientens behov og energikapasitet. God samhandling forutsetter stor grad av fleksibilitet i samarbeidet mellom pasient/pårørende og saksbehandler for å sikre at pasienten får de tjenester som er mest hensiktsmessige.

I spesialisthelsetjenesten har alle pasienter som henvises til et behandlingssted krav på vurdering av sin helsetilstand innen 30 virkedager etter henvisningen er mottatt. Vurderingen av henvisningen foretas ut fra hvor alvorlig tilstanden er, hvilke muligheter som finnes for å forbedre den med helsehjelp, og en vurdering av om kostnadene ved helsehjelpen står i forhold til nytten for pasienten. Vurderingen gir pasienten enten rett til prioritert helsehjelp (rettighetspasient), helsehjelp eller avslag på tilbud om helsehjelp. Rettighetspasienter får en frist for når spesialisthelsetjenesten senest skal ha startet helsehjelpen, enten i form av behandling eller i form av videre utredning. De som har krav på helsehjelp, men ikke er rettighetspasienter, får ikke en juridisk bindende frist for oppstart av behandling, men informasjon når en kan forvente at helsehjelpen blir gitt. Pasienter som har blitt vurdert og ikke anses som rettighetspasient, kan be om en fornyet vurdering fra spesialisthelsetjenesten, med visse unntak. Hvis spesialisthelsetjenesten ikke klarer å starte den planlagte utredningen/-behandlingen innen den fristen rettighetspasienten har fått, kan den kontakte HELFO-pasientformidling på 81533533. 


\subsection{Klagemulighet}

Hvis pasienten, eller den som representerer pasienten, mener at den ikke har fått oppfylt sine pasientrettigheter, har de rett til å klage til Fylkesmannen. Klagen sendes til den som har truffet avgjørelsen (for eksempel legen eller kommunen). Hvis avgjørelsen blir opprettholdt, skal den som opprettholder avgjørelsen sende klagen videre til Fylkesmannen. Klagen skal være skriftlig. Fristen for å klage er fire uker fra pasienten fikk, eller burde ha fått, tilstrekkelig kunnskap til å fremme en klage. Hvis instansen pasienten klager til, ikke gir medhold, kan pasienten bringe klagen inn for et høyere organ. Nærmere informasjon om dette skal fremkomme av svaret på klagen.

\subsection{Pasient- og brukerombudet}

Ombudet har i oppgave å arbeide for å ivareta pasientens og brukerens behov, interesser og rettssikkerhet overfor helsetjenesten og sosialtjenesten, og for å bedre kvaliteten i tjenestene. Pasienter som har hatt opplevelser i helse- og sosialtjenesten som de ønsker å ta opp, kan ta direkte kontakt med Pasient- og brukerombudet i fylket der de bor. Ombudet kan gi råd, veiledning og informasjon om rettigheter som pasient, bruker eller pårørende. Pasient- og brukerombudet kan også bistå med å formulere og videreformidle spørsmål eller klage til rette instans. http://www.pasientombudet.no/ 


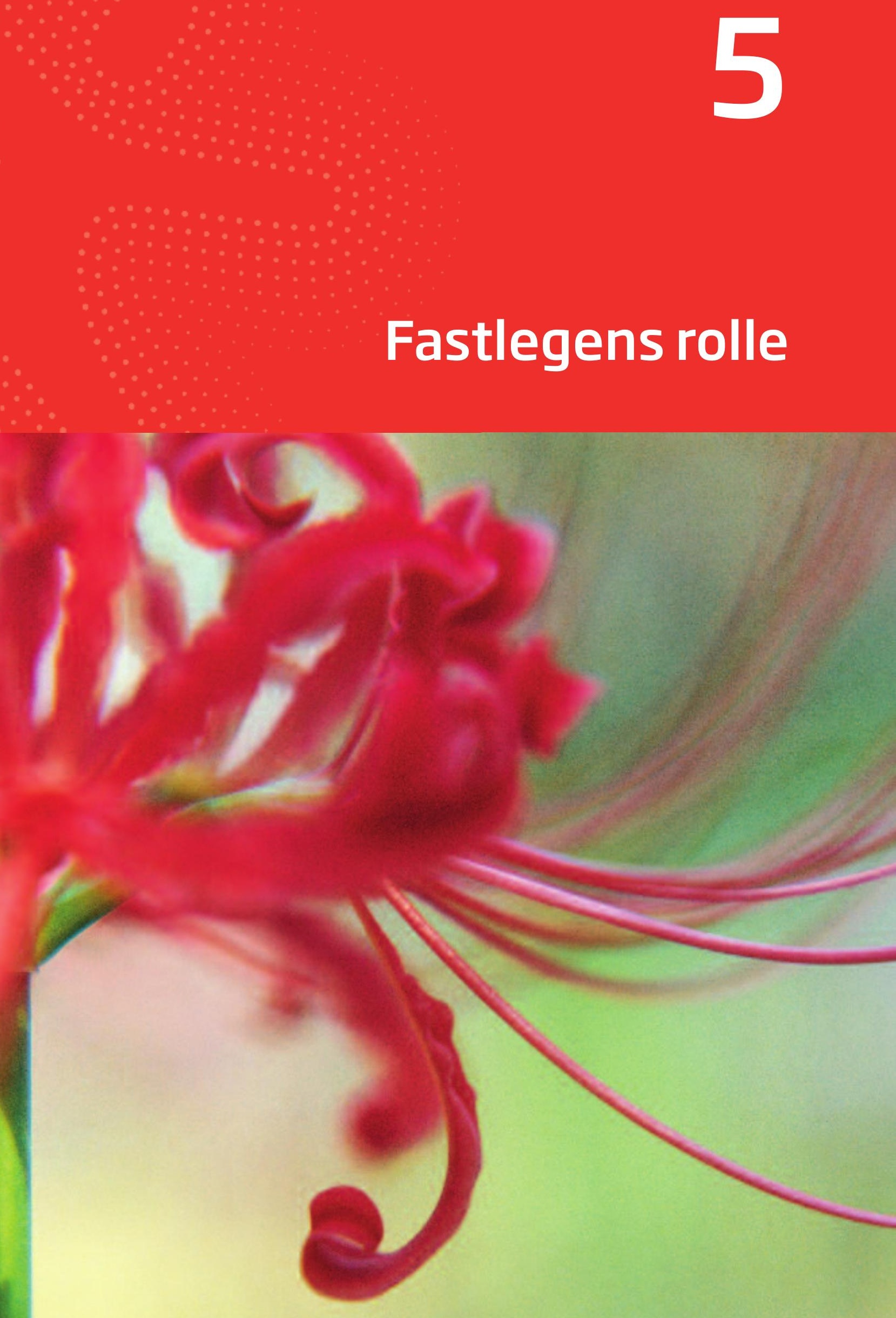


Fastlegen vil ofte være den første i helsetjenesten som møter pasienter med symptomer på CSF/ME og deres pårørende. Det er en stor utfordring å stå overfor pasienter som åpenbart er syke, men hvor årsakene til symptomene og selve sykdommen ikke nødvendigvis er kjent. Fastlegen har hovedansvar for utredning av voksne, beskrevet i kap. 2. Utredning av barn gjøres i samarbeid med spesialisthelsetjenesten. Fastlegen har oppfølgingsansvar for hele pasientgruppen. Fastlegene må ha kompetanse på CFS/ME for å sikre godt tilbud til pasienter og pårørende. Nasjonal kompetansetjeneste for CFS/ME på OUS vil holde kurs for fastleger og være tilgjengelige for kontakt og rådgivning ved behov.

\subsection{Fastlegens oppgaver}

Det er viktig å sette av god tid til første konsultasjon enten den skjer på kontoret eller hjemme hos pasienten. Erfaringer fra praksisfeltet tyder på at det er hensiktsmessig å sette av 11/2 time, gjerne med innlagt pause, til dette. Det er viktig at fastlegen prioriterer hjemmebesøk til denne pasientgruppen både i forhold til utredning og oppfølging når det er nødvendig begrunnet i pasientens nedsatte funksjonsnivå. Hovedfokus er grundig sykehistorie og klinisk undersøkelse sett i relasjon til diagnostiske kriterier for å vurdere CFS/ME-diagnosen hos pasienter med langvarig alvorlig utmattelse og aktuelle tilleggssymptomer.

- Som for andre pasientgrupper må det gjøres en faglig forsvarlig og individualisert utredning av aktuelle differensialdiagnoser, gjerne i samarbeid med spesialisthelsetjenesten, for å utelukke annen underliggende patologi. Se kapittel 2 for utredning og diagnostisering.

- Spesialist i allmennmedisin kan stille diagnosen, det anbefales å kode CFS/ME som ICPC-2 A04, og journalføre hvilket kriteriesett som er brukt i utredningen.

- En god behandlingsallianse med pasient og pårørende er viktig og at disse tas med på råd i forhold til hva som er mulig og hensiktsmessig i forbindelse med utredning og behandling. Det å få en diagnose kan ofte oppleves som lettende for pasienten, som ofte har lange utredningsløp bak seg. Diagnosen vil også kunne utløse rettigheter for pasienten, jfr kapittel 3 om behandling og kapittel 4 om koordinator og individuell plan. Avtal regelmessig kontakt for oppfølging, for eksempel 2-4 ganger pr år, og vurder fortløpende underveis om det er relevant å ta i bruk individuell plan. Fastlegen kan også bidra til at det eventuelt blir utpekt en koordinator ved å ta kontakt med koordinerende enhet for habilitering og rehabilitering $\mathrm{i}$ kommunen.

- Fastlegen er sentral for å sikre godt samarbeid med kommunens tjenesteapparat som for eksempel bestillerkontor, hjemmesykepleie, hjemmehjelp, fysioterapi, ergoterapi og eventuelt psykolog, samt evt sosialfaglig personell innen skole, utdanning og jobb. Se liste over faggrupper som kan være aktuelle i kapittel 6.2.

- Pasienter med CFS/ME kan også ha, og få, andre sykdommer. Nye symptomer eller forverring av eksisterende symptomer skal følges opp på faglig forsvarlig måte, samtidig som det er viktig å sette strek for utredning når denne er sluttført. Pasienten trenger ofte hjelp av fastlegen til å «sortere» hvilke symptomer som tilhører CFS/ME-diagnosen, og hva som kan skyldes andre forhold.

- Nye sykmeldingsregler som ble innført i 1. juli 2011 gir sykmelder et større mulighetsrom enn tidligere og åpner i større grad for en vektlegging av brukerens ressurser. Nye regler om Arbeidsavklarings penger erstatter tidligere rehabiliteringspenger, attføringspenger og tidsbegrenset uførestønad. For å fylle dette vilkåret er det nødvendig med en grundig og bred arbeidsevnevurdering i NAV når pasienten 
er i stand til det. Egenmelding, avventende sykmelding og gradert sykmelding er alternativer til full sykemelding, og kan benyttes i en del tilfeller. I følge arbeidsmiljøloven har arbeidsgiver en tilretteleggingsplikt for arbeidstaker «så langt det er mulig». En god dialog mellom bruker, sykmelder og arbeidsgiver er viktig for å sikre at bruker kan ha et godt tilpasset arbeidsbelastning i sykdoms perioden. Pasienter med CFS/ME følges opp i tråd med arbeidsmiljøloven og folketrygdloven som sikrer tett oppfølging av sykemeldte. Sykemelder skal motta oppfølgingsplan fra arbeidsgiver, delta i dialogmøte, og vurdere gradert sykemelding.

http://sykmelderveileder.helsedirektoratet.no/Sider/default.aspx

\subsection{Utarbeidelse av erklæring til NAV}

Krav til diagnostisk utredning og dokumentasjon

Fastlege som er spesialist i allmennmedisin kan stille diagnosen, styre utredning og utarbeide dokumentasjon til NAV. Det vil som hovedregel være nødvendig med vurdering hos en spesialist i tillegg, der spesialitet er avhengig av sykdomsbildet til pasienten. Dersom kravet til vurdering hos annen spesialist skal fravikes, må dette begrunnes særlig. Vurdering av spesialist i tillegg til fastlege, vil bidra til å sikre diagnosen - som er en eksklusjonsdiagnose - gjennom tverrfaglige overveielser. Fastlege som ikke er spesialist i allmennmedisin, kan styre utredningen og utarbeide dokumentasjon til NAV på grunnlag av aktuelle epikriser og spesialistopplysninger.

NAVs krav til diagnostikk av sykdommen:

- Sykdomsbildet må være typisk med ekstrem utmattelse

- Utredning må utelukke annen sykdom som årsak til nedsatt funksjonsevne

For at personer med kronisk utmattelsessyndrom skal fylle de medisinske vilkårene for rett til uføretrygd (mai 2015) må følgende krav være oppfylt hva gjelder sykdomstilstanden:

- Legeerklæring fra fastlege/spesialist i allmennmedisin og som hovedregel fra en annen relevant spesialist i tillegg, med dokumentasjon av gjennomgått medisinsk utredning og behandling (eks. gradert trening, kognitiv terapi, mestringskurs).

- Grundig funksjonsvurdering og dokumentasjon på at sykdommen har ført til en funksjonsnedsettelse

- Sykdommen skal være varig. Med varig menes ikke livsvarig men langvarig. Det retningsgivende varighetskravet anslås til 7 år eller mer regnet fra det tidspunktet uførheten oppsto. Samtidig vil ikke varighetskravet være oppfylt dersom personen har vært arbeidsufør i for eksempel 6 år men antas å komme tilbake i arbeid $i$ løpet av noen få år fra vedtakstidspunktet. Dette innebærer at dersom det antas at tilstanden vil endre seg vesentlig i løpet av noen år, antas varighetskravet ikke å være oppfylt.

Det må dokumenteres at funksjonsevnen er vesentlig nedsatt på grunn av sykdomstilstanden og at inntektsevnen/arbeidsevnen er nedsatt med minst $50 \%$. Sykdommen må være hovedårsak til nedsettelsen av inntektsevnen. (Mai 2015) 


\section{6}

Helse- og omsorgstjenester 
Pasienter med CFS/ME er en sammensatt gruppe, og det er store forskjeller i funksjonsnivå. Derfor er det nødvendig med individuelle løsninger og tett samhandling mellom tjenestenivåene.

Ansatte i helse- og omsorgstjenesten kan møte svært syke personer og slitne familier. Noen få personer er så dårlig at de må motta døgnkontinuerlig pleie på institusjon eller hjemme. Å gi tjenester til pasienter som ikke har en klar og entydig anerkjent årsak til sin sykdom, stiller store krav til faglig kvalitet, profesjonalitet og utforming av tjenestetilbudet. Respekten for den enkeltes liv skal være i fokus, og helsepersonells møte med pasienter med CFS/ME må preges av omsorg og respekt.

\subsection{Tverrfaglig innsats}

Samhandling og helhetlig tilnærming er nødvendig for å gi pasienter med CFS/ME optimal effekt av tiltakene. Dette gjelder både i primærhelsetjenesten og i spesialisthelsetjenesten, og ikke minst i samarbeidet mellom disse. Mange pasienter har behov for tjenester fra begge nivåer i helsetjenesten. I arbeidet med barn og unge med CFS/ME er et godt tverrfaglig samarbeid mellom skole og (skole-) helsetjenesten av vesentlig betydning. Pedagogisk-psykologisk tjeneste (PPT) kan også være aktuelt å involvere for å få et tilpasset undervisningsopplegg. Ved langvarig skolefravær uten klar årsak, har skolen plikt til å sende bekymringsmelding til barnevernet.

Hvilke tjenester det er behov for vil variere fra pasient til pasient og i løpet av sykdomsforløpet. Faggrupper vil kunne ha noe ulike ansvarsområder og dette bør tydeliggjøres i samarbeidsmøter og/eller i individuelle planer.

\section{Utviklingsprosjekter - Pasientforløp}

Det er behov for gode modeller for helhetlige pasientforløp. Dette betyr god samhandling mellom tjenesteytere. Utfordringen er å finne gode lokale løsninger, basert på faglig forsvarlighet. Brukermedvirkning er sentralt i denne typen utviklingsprosjekter.

Klinikk medisin og klinikk fysikalskmedisin og rehabilitering, Sykehuset i Vestfold HF leder et prosjekt, finansiert av Helsedirektoratet, hvor målet er å etablere en helhetlig, forutsigbar og kunnskapsbasert behandlingslinje for pasienter med CFS/ME. Behandlingslinjen skal gjelde fra det oppstår mistanke om CFS/ME og gjennom kvalitetssikret diagnostikk og behandling til oppfølging i hjem, skole og arbeid. Standard kriterier for utredning før henvisning til spesialisthelsetjenesten skal utarbeides og kurs for fastleger inngår i prosjektet. Samarbeid med oppfølgende instanser i kommuner og NAV er i startfase. Kompetanseheving er etterspurt og igangsatt. Dette er en forutsetning for å få til et godt samarbeid i det videre arbeidet.

\section{Avdeling for fysikalsk medisin og rehabilitering, Rehabiliteringsklinikken, Helse Bergen HF} leder et prosjekt, finansiert av Helsedirektoratet, hvor hovedmålet er å utvikle en brukerorientert samhandlingsmodell med skriftlige, forpliktende samarbeidsavtaler mellom spesialisthelsetjenesten, primærhelsetjenesten og NAV. Prosjektet er et samarbeid mellom Helse Bergen, Bømlo kommune, NAV Bømlo og brukere. Pasientgruppen inkluderer 24 pasienter som har fått diagnosen fra 1999-2011, med ulikt symptomforløp og ulik alvorlighetsgrad. Pasientenes fysiske, kognitive og sosiale funksjon kartlegges med verktøy innenfor rammen av ICF (se punkt 3.6). På dette grunnlag utarbeides et standardisert forløp for den enkelte. Behovet for samarbeid og ansvarsfordeling mellom primærhelsetjenesten og spesialisthelsetjenesten blir avklart gjennom en slik kartlegging. 


\subsection{Faggrupper som kan inngå i oppfølging av pasienter med CFS/ME}

Under følger en oversikt over faggrupper som kan være aktuelle bidragsytere i tverrfaglig arbeid med pasienter med CFS/ME. Det kan også være behov for andre spesialiteter, så listen er ikke uttømmende. Noen faggrupper er mer vanskelig tilgjengelige enkelte steder i landet enn andre. Oversikten gir noen eksempler på hvilke oppgaver hver enkelt faggruppe kan ha i arbeidet. Noen av oppgavene overlapper arbeidsoppgavene til andre samarbeidende faggrupper. Det er viktig å lage en strukturert plan og følge opp pasienten jevnlig.

Fastlege, spesialist i allmennmedisin: (Se også kapittel 5 samt vedlegg 1-3). Har ansvar for utredningen av voksne pasienter ved mistanke om CFS/ME, både ved å undersøke pasienten selv, rekvirere prøver og ved behov å henvise til relevante spesialister underveis i utredningen. Når diagnosen er stilt, er fastlegen den som følger opp pasienten, både når det gjelder barn og voksne. Dette er også viktig i forbindelse med søknader om ytelser fra NAV eller ved behov om hjelp fra kommunale tjenester. Fastlegen kan også hjelpe pasienten med å finne ut om nye symptomer er en del av CFS/ME bildet, eller om de kan tyde på en annen sykdom. Ved behov må fastlegen dra på hjemmebesøk, blodprøver må også rekvireres selv om pasienten må ha konsultasjon i hjemmet. Fastlegen kjenner ofte pasientens familiesituasjon og kan gi råd bl.a. i forhold til barn som pårørende, samt gi informasjon om individuell plan. Det er viktig med regelmessig oppfølging, hvor hyppig oppfølgingen skal være må avhenge av klinikken, men ikke sjeldnere enn 2-4 ganger per år.

Fysioterapeut: Kan bidra til å finne rett balanse mellom aktivitet og hvile, noe som er et sentralt aspekt $\mathrm{i}$ mestring av CFS/ME. Det vil si å ha aktivitet innenfor et nivå der pasienten har det godt etterpå, eller henter seg inn etter maks ett døgn. Da kan progresjon i aktivitet komme naturlig innenfra - fra egne behov - og bedring av tilstanden kan komme av seg selv. Det er viktig å forstå sammenheng mellom fysiske og kognitive aktiviteter og konsekvenser disse har på symptomer og på sykdommen. De fleste pasienter med CFS/ME tåler ikke, eller reagerer med forverring, på de vanlige behandlings- eller treningsformene hvis disse ikke er spesielt og individuelt tilpasset og avpasset. Fysioterapeuter kan også instruere pasienter i avspenningsteknikker som kan brukes i mikropauser når en aktivitet blir for belastende eller for å bedre kvaliteten på hvile og søvn. Fysioterapeuten kan i tillegg bidra med orientering om øvelser for å bedre balansen. Se også www.cfstreningsbehandling.no

Ergoterapeut: Kan hjelpe pasientene til å oppnå et mest mulig stabilt funksjonsnivå ut fra egne forutsetninger. Dette kan gi økt mestring av daglige aktiviteter slik at hverdagen kan fungere bedre for den enkelte. Ergoterapeut kartlegger daglige aktiviteter som er knyttet til hjem, arbeid, skole/utdanning, fritid og hvile. Dette bidrar til en økt bevisstgjøring rundt døgnrytme, aktuelt aktivitetsnivå og energibruk. Ut i fra dette gir ergoterapeuter råd og veiledning i forhold til det å få en mer optimal struktur på døgnet, og i forhold til aktivitetsavpasning og energiøkonomisering. Aktivitetsavpasning betyr at aktivitetsnivået bør avpasses opplevd mengde energi, det vil si at aktiviteter bør avsluttes når pasienten begynner å bli sliten og før slitenheten går over i utmattelse. Det fokuseres på at både fysisk, kognitiv/mental og sosial aktivitet krever energi. Energi -økonomisering betyr å utføre aktiviteter ved bruk av minst mulig energi. I arbeid med barn og unge er det ofte aktuelt å ta utgangspunkt i skole og timeplan når man skal kartlegge aktivitsnivået og veilede barnet i å forstå prinsippet aktitetsavpasning. Dette vil ergoterapeuter ta tak i og på den måten kunne være et bindeledd til skolen. (Mai 2015) Ergoterapeuter kan i tillegg anbefale, og søke om, tekniske hjelpemidler som kan gjøre deltakelse mindre energikrevende og fremmer deltakelse for den enkelte. Hjelpemidler kan for mange bidra til å (Mai 2015) lette pleiesituasjonen. Målsetningen er mestring av hverdagen gjennom å være så aktiv som mulig samtidig som pasienten unngår forverring.

Klinisk ernæringsfysiolog: En del pasienter med CFS/ME rapporterer at de føler seg bedre på et kosthold som gir lite svingninger i blodsukkeret. Mange opplever at noen matvarer er uheldige for dem å spise. Klinisk ernæringsfysiolog kan, sammen med pasienten, bidra for å skaffe oversikt over kostholdet og symptombildet, og ut ifra disse opplysningene vurdere om en kostomlegging kan lette på noen av symptomene. De kan også hjelpe pasienten med å finne et kosthold som inneholder de næringsstoffene 
pasienten trenger når viktige matvarer må unngås pga matvareoverfølsomhet. De kan gi råd om eventuelle kostendringer som pasienten opplever som gjennomførbare, og også gi råd om tilrettelegging i forhold til innkjøp og tilberedning av mat. Klinisk ernæringsfysiologer er i spesialisthelsetjenesten, men sjelden $\mathrm{i}$ kommunene.

Sosionom: Sørger for sosial kartlegging samt veiledning og informasjon om rettigheter som pasienten kan ha nytte av. Det gjelder så vel folketrygden som kommunale og statlige hjelpeordninger. Det kan gis råd og praktisk hjelp med å overkomme barrierer i forhold til hjelpeapparatet, og hjelp til å fylle ut søknader. Gjennom samtaler med pasient og pårørende og kjennskap til hjelpeapparatet tas det sikte på å klargjøre om det finnes ressurser i pasientens nærmiljø, familie eller nabolag eller øvrig nettverk, som kan mobiliseres. Sosial kartlegging kan bidra til å skaffe oversikt over hvordan sykdommen påvirker hele familien, og bidra til at familien får den hjelp og avlastning som kan skaffes. Spesielt er det viktig at sosionomen bidrar til dette hvis pasienten har barn.

Sosionomen kan både gjennom individuelle samtaler og nettverksintervensjon bidra til at pasienten noe lettere kan komme til å mestre og akseptere sin sykdom, og bli bevisst sine måter å takle sykdommen på. Dette kan også andre faggrupper bidra til.

Psykolog: De fleste kroniske sykdommer også CFS/ME, kan medføre at pasienter får psykiske reaksjoner som følge av sykdommen eller andre ting som skjer i livet. Dette kan igjen ha betydning for og få negativ innvirkning på hvordan man opplever, tenker og lever med sykdommen. Pasienter som har hatt dramatiske sykdomsopplevelser vil kunne ha nytte av psykologisk bistand for å bearbeide slike erfaringer. Aktivitetsavpasning og energiøkonomisering handler i stor grad om å endre egne holdninger til aktivitet og hvile. Psykologer kan bistå pasienter med dette og det finnes flere psykologiske tilnærminger inkludert kognitiv terapi, som er godt egnet til denne form for livsstilsendring. Mange psykologer kan også bistå i den jobben som pasientene må gjøre for å styrke positive aspekter og opprettholde god psykisk helse og livskvalitet. Psykologer kan også bidra i diagnostisering og annen utredning, samt eventuell henvisning videre til annen psykologisk utredning eller behandling f eks nevropsykolog der det er nødvendig, eller til tverrfaglige rehabiliterings- og mestringstilbud. CFS/ME pasienter blir mange ganger henvist til psykologisk utredning eller behandling ved distriktspsykiatriske senter som del av fastlegens CFS/ME utredning. I slike tilfeller er det ikke bare snakk om å påvise, diagnostisere og sette diagnoser, men mer spesifikt er det viktig at psykologen utreder hvorvidt f eks. depresjon, angst eller stress og traumer er en reaksjon på, har bidratt til, eller på noen måte kan forklare, opprettholde eller forverre sykdom og symptomer. Dersom CFS/ME pasienten viser seg også å være deprimert eller ha andre psykiske tilstander har de krav på og bør tilbys adekvat psykologisk behandling for dette på linje med andre pasienter.

Psykiatrisk sykepleier: Se også innledningen i punkt ovenfor «psykolog». Psykiatrisk sykepleier kan når pasienten ønsker det tilby samtaler vedrørende psykiske reaksjoner på sykdommen, stress, uheldige tanke- og handlingsmønstre samt bevisstgjøring av ressurser for god mestring.

Sykepleier: Sykdomsgraden vil være avgjørende for hvilke funksjonsnivåer og hjelpebehov pasientene har. Bl.a. vil de som er syke i slik grad at de trenger pleie kunne ha behov for hjelp fra hjemmesykepleien. Sykepleier kan hjelpe til med bl.a. tilrettelegging, pleie, ernæring, forflytning, medisinadministrering, blodprøvetaking og, ikke minst, observasjon. Sykepleier er viktig i samarbeidet med fastlegen (se også kapittel 5).

Vernepleier: CFS/ME syke har behov for tjenester over tid og gjerne med innhold med fokus på sosiale og miljømessige forhold. En vernepleier er kvalifisert til å utføre miljøarbeid, legemiddelhåndtering, habiliterings- og rehabiliteringsarbeid sammen med mennesker med fysiske, psykiske og/eller sosiale funksjonsvansker som ønsker og har bruk for slike tjenester.

Andre aktuelle faggrupper: Det er erfaring med at idrettspedagoger, fritidsaktivitører/treningsveiledere og DAT instruktør (dyreassistert terapeut) kan ha noe å tilby pasientgruppen. 


\subsection{Spesialisthelsetjenestens rolle}

Barn og unge hvor en mistenker CFS/ME bør utredes av spesialist i barnemedisin, og det er spesialisten som stiller diagnosen. Det anbefales at lokale barneavdelinger har kontakt med pasientene to til tre ganger $i$ året for å følge opp nye eller eventuelt endrede symptomer, og for å forsikre seg om at pasienten har oppfølging lokalt. (Mai 2015)

Når det gjelder voksne, kan fastlegen, spesialist i allmennmedisin, vurdere at henvising til, og samarbeid med, spesialisthelsetjenesten er viktig og nødvendig i utredning av pasienter med mulig CFS/ME. Spesialisthelsetjenesten kan bistå med relevant og målrettet utelukkelsesdiagnostikk og/eller bekreftelse av diagnosen CFS/ME. De kan også bidra gjennom tverrfaglige funksjonsvurderinger og etablering av realistiske rehabiliteringsløp for den enkelte pasient. Innenfor poliklinisk virksomhet og ambulante team kan pasienten få hjelp til aktivitetskartlegging og utprøving av rehabiliteringstiltak. Spesialisthelsetjenesten skal også bistå med veiledning til kommunehelsetjenesten ved behov og medvirke til oppbygging av kompetanse lokalt.

\subsection{Nasjonal kompetansetieneste}

I 2012 ble det opprettet Nasjonal kompetansetjeneste for CFS/ME ved Oslo universitetssykehus som omfatter både barn, unge og voksne. Tjenesten utgår fra ME/CFS-senteret som tar seg av pasienter over 18 år, og CFS/ME teamet ved Barneavdeling for nevrofag som har ansvaret for barn og unge. Kompetansetjenesten baserer seg på den samlede kompetansen, og drives etter kravene i forskrift om godkjenning av sykehus, bruk av betegnelsen universitetssykehus og nasjonale tjenester $\mathrm{i}$ spesialisthelsetjenesten.

\section{§ 4-6. Oppgaver for nasjonale kompetansetjenester}

Nasjonale kompetansetjenester skal ivareta følgende oppgaver innenfor sitt ansvarsområde:

- Bygge opp og formidle kompetanse.

- Overvåke og formidle behandlingsresultater.

- Delta i forskning og etablering av forskernettverk.

- Bidra i relevant undervisning.

- Sørge for veiledning, kunnskaps- og kompetansespredning til helsetjenesten, andre tjenesteytere og brukere.

- Iverksette tiltak for å sikre likeverdig tilgang til nasjonale kompetansetjenester.

- Bidra til implementering av nasjonale retningslinjer og kunnskapsbasert praksis.

- Etablere faglige referansegrupper.

- Rapportere årlig til departementet eller til det organ som departementet bestemmer.

Det er utarbeidet en veileder til forskriften: Veileder til Forskrift nr 1706 av 17. desember 2010 om godkjenning av sykehus, bruk av betegnelsen universitetssykehus og nasjonale tjenester i spesialisthelsetjenesten. Den gir utfyllende kommentarer til kapittel 4 i forskriften. Med bakgrunn i dette er det opprettet en referansegruppe hvor alle helseregioner er representert. I tillegg er to brukerorganisasjoner representert, samt kommunehelsetjenesten. Referansegruppen skal sikre at den Nasjonale Kompetanse tjenesten er organisert og drevet i tråd med kriteriene fastsatt i forskriften.

Kompetansetjenesten vil holde kurs for helsepersonell for å øke kunnskapen i forhold til denne sykdoms gruppen. Videre vil den etablere en nettside med oppdatert informasjon mht diagnostikk, behandling og tilrettelegging. Nettsiden vil også være oppdatert i forhold til hva som skjer innenfor forskning. Kompetansetjenesten vil samarbeide med brukerorganisasjonene, og den vil være en høringsinstans for helsemyndighetene. 


\subsection{Ambulant virksomhet og veiledning til kommunene}

Helse- og omsorgsdepartementet har tydeliggjort at tjenestetilbudet til pasientgruppen skal prioriteres. De regionale helseforetakene skal sikre adekvat tilbud om diagnostikk, behandling og rehabilitering, herunder tilbud om lærings- og mestringskurs, til pasienter med CFS/ME. For informasjon om Lærings og mestringssentrene, se sykehusenes egne hjemmesider. Tilbudet skal utvikles i samarbeid med kommunene. Regionale helseforetak kan ta i bruk utrednings-døgntilbudet til de sykeste pasientene med CFS/ME i Oslo Universitetssykehus HF.

Helsedirektoratet mener det må være et mål at ambulante team opprettes i alle helseregioner, og flere helseregioner har et slikt team. Ambulante team bør betjene barn, unge og voksne med vekt på å nå de aller sykeste. Pasienter med CFS/ME har behov for behandling og oppfølging der de bor, og kunnskapsoverføring fra spesialisthelsetjenesten til kommunehelsetjenesten vil gjennom ambulante team være et viktig bidrag, jf. spesialisthelsetjenestelovens $§$ 6-3 Veiledningsplikt overfor kommunehelsetjenesten.

Ved ME/CFS-senteret, OUS, er det et nasjonalt døgnbasert tilbud (1 sengeplass) for voksne. Dette tilbudet innebærer et to-ukers opphold hvor pasientene får tverrfaglig utredning og rådgivning. OUS har også et døgnbasert tilbud til barn/unge (en sengeplass) som er ment for tverrfaglig utredning og vurdering over 1-2 uker med sikte på overføring til lokalt hjelpeapparat.

\subsection{Spesialisthelsetjenestens tilbud}

Lokalsykehusene skal fra 2010 ha et poliklinisk tilbud for pasienter med CFS/ME.

\section{Regionale tilbud:}

Barn:

\section{Helse Nord}

Barneavdelingen ved barne- og ungdomsklinikken

Universitetssykehuset i Nord-Norge (UNN)

9038 Tromsø

Helse Midt har for tiden ikke noe regionalt tilbud

\section{Helse Vest}

Seksjon for barnenevrologi og habilitering

Barneklinikken, Haukeland universitetssykehus

5021 Bergen

Telefon $55975200 / 55975184$

\section{Helse Sør-Øst}

CFS/ME teamet

Barneavdeling for nevrofag

Oslo universitetssykehus HF Rikshospitalet

Postboks 4950 Nydalen

0424 Oslo

Telefon 23072699 
Voksne:

\section{Helse Nord}

Universitetssykehuset i Tromsø, Tverrfaglig CFS/ME-team

Telefon ekspedisjon (dagtid mandag til fredag) 776-69163 / 69984

www.unn.no/fysmedpolog www.helse-nord.no/rehabilitering

\section{Helse midt}

CFS/ME poliklinikk ved St. Olavs Hospital

Telefon ekspedisjon CFS/ME poliklinikk: 72822547 / 72822491 kl.9-15.30

http://www.stolav.no/no/Om-oss/Avdelinger/Smerte-og-sammensatte-symptomlidelser-

Smertesenteret/Enheter1/CFS-ME-poliklinikken/

\section{Helse Vest}

Avdeling for fysikalsk medisin og rehabilitering, AFMR, Helse Vest, Bergen

Telefon 55918400

http://haukeland.no/omoss/avdelinger/fysmed/Sider/enhet.aspx

\section{Helse Sør-Øst}

ME/CFS senteret (en regional utredningsplass døgnopphold, poliklinikk og ambulant team),

Oslo Universitetssykehus

Telefon helsepersonell: 23033101

Pasienthenvendelser: 23033105

Telefontid: alle dager mellom kl. 9 til 14

http://www.os/o-universitetssykehus.no/omoss/avdelinger/mecfs-senteret/Sider/enhet.aspx

\section{Nasjonale utredningsplasser for barn og ungdom (under 18 år)}

CFS/ME teamet

Barneavdeling for nevrofag

Oslo universitetssykehus HF Rikshospitalet

Postboks 4950 Nydalen

0424 Oslo

Telefon 23072699

\section{Nasjonale utredningsplasser for voksne:}

ME/CFS senteret, Oslo Universitetssykehus (1 sengeplass)

Telefon helsepersonell: 23033101

Pasienthenvendelser: 23033105

Telefontid: mandag, tirsdag, torsdag og fredag kl. 9 til 14

http://www.oslo-universitetssykehus.no/omoss/avdelinger/mecfs-senteret/Sider/enhet.aspx

\section{Nasjonal kompetansetjeneste for CFS/ME}

Telefonnummer til nasjonal kompetansetjeneste: 23072790 http://www.os/o-universitetssykehus.no/kompetanseCFSME

E-post: kompetansecfsme@ous-hf.no 


\subsection{Tilrettelegging ved døgnopphold}

Det er en utfordring å tilrettelegge for de aller sykeste og gi dem et tilbud om diagnostisering, oppfølging og mestring av sin sykdom.

Pasienter med CFS/ME møter ekstra utfordringer ved å være innlagt i sykehus. Mange opplever å være meget ømfintlig for sanseinntrykk og har behov for spesielt tilrettelagte rom med tanke på lyd-og lysskjerming. Mange av de syke trenger at all hjelp og bistand blir utført ut fra kjente rutiner på nøyaktig samme måte hver gang, og uten at de selv, eller andre, må rettlede i løpet av rutinen (se boks 2).

Pasientene opplever det som en belastning å måtte forholde seg til at det er mange ansatte i avdelingen. Prøvetaking og undersøkelser de skal gjennom kan føre til forverring av symptomer. Også pasienter som ikke er i stadiet alvorlig/svært alvorlig grad opplever risiko for forverring av et sykehusopphold. For de alvorligst syke oppleves ikke innleggelse på sykehus som et mulig alternativ uten fare for sterk forverring.

\subsection{Oversikt over tilbud om rehabilitering}

Både spesialisthelsetjenesten og kommunene er pålagt å ha en koordinerende enhet for habilitering og rehabilitering, jf. $\S 6$ og $\S 11$ i Forskrift om habilitering og rehabilitering, individuell plan og koordinator. Den koordinerende enheten skal ha generell oversikt over habiliterings- og rehabiliteringstilbudene i kommunen og i helseregionen, og enheten skal være et kontaktpunkt for samarbeid. Koordinerende enhet for habilitering og rehabilitering har det overordnede ansvaret for individuell plan, jf. § 18-2 i Forskrift om habilitering og rehabilitering, individuell plan og koordinator.

Informasjonstelefonen for rehabilitering i spesialisthelsetjenesten - 80030061 - har helsefaglig personell og nettsted med oversikt over tilgjengelige rehabiliteringstjenester i helseregionene med avtaler om å gi tilbud til denne diagnosegruppen.

Koordinerende enhet for habilitering og rehabilitering i kommunen kan kontaktes for oversikt om rehabiliteringstilbud. 


\subsection{Private institusjoner med offentlig avtale}

Mange private rehabiliteringsinstitusjoner har avtale med Regionale helseforetak om å gi tilbud til pasienter med CFS/ME. Rehabiliteringstelefonen vil ha oppdatert oversikt over det gjeldende tilbudet, pr. mai 2012 har følgende institusjoner et tilbud:

\section{Helse Sør Øst}

Barn/ungdom:

- Catosenteret

http://www.catosenteret.no/

Voksne:

- Skogli Helse- og rehabiliteringssenter AS

http://www.skogli.no/

- Sørlandets rehabiliteringssenter Eiken http://www.sorlandets-rehab.no/ee/

- Vikersund kurbad AS

http://www.vikersund-kurbad.no/

- Rehabiliteringssenteret AIR, Rauland http://www.air.no/

- Friskvernklinikken, Asker http://www.friskvern.no/

\section{Helse Vest}

- Røde Kors Haugland Rehabiliteringssenter http://www.rkhr.no/

- Frihamnsenteret (psykiatrisk spesialistpraksis)

Barn/ungdom:

- Catosenteret http://www.catosenteret.no/

\section{Helse Midt}

- CoperioSenteret Rehabiliering http://www.coperio.no/

\section{Helse Nord}

\section{Barn/ungdom:}

- Valnesfjord Helsesportsenter http://www.vhss.no/?ac_id=1\&ao_name=hjem

- Catosenteret http://www.catosenteret.no/

Voksne:

- Rehabiliteringssenteret Nord-Norges kurbad http://www.kurbadet.no/ 


\section{Kvalitet, faglig forsvarlighet og kunnskapsbasert praksis}

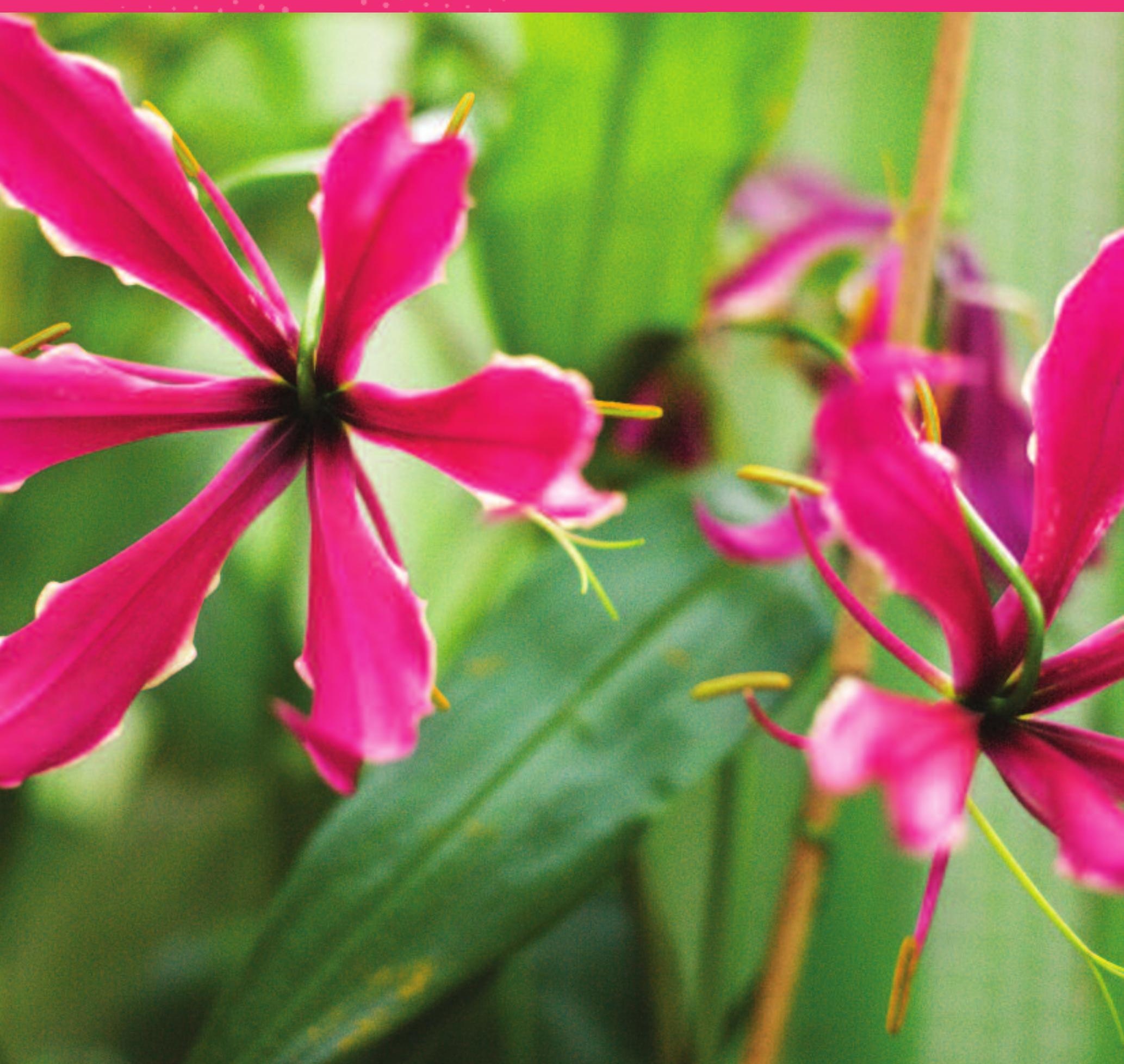




\subsection{Kvalitet}

Sentralt i utviklingen av gode helse og omsorgstjenester står fokus på god kvalitet. Kvalitetsarbeid i helsetjenesten er lovpålagt, blant annet i helse- og omsorgstjenesteloven og spesialisthelsetjenesteloven. Helsedirektoratet har i samarbeid med fagmiljøene, utviklet en «Nasjonal strategi for kvalitetsforbedring i sosial- og helsetjenesten ...0g bedre skal det bli! (2005-2015)».

Tjenester av god kvalitet:

- ervirkningsfulle

- er trygge og sikre

- involverer brukerne og gir dem innflytelse

- er samordnet og preget av kontinuitet

- utnytter ressursene på en god måte

- er tilgjengelig og rettferdig fordelt

Tjenestene må kontinuerlig utvikles og forbedres fordi:

- samfunn, kunnskap, kompetanse og teknologi er i stadig endring og utvikling

- brukernes forventninger og krav til medvirkning endrer seg

- tjenestene ikke alltid virker etter hensikten

- tjenestene ikke er så trygge og sikre som de bør og kan være

- tjenester kan være dårlig samordnet

- det er rom for forbedring når det gjelder ressursutnyttelse og fordeling

Kvalitetsstrategien peker på god ledelse som en forutsetning for å oppnå kvalitet i tjenestetilbudet. Det understrekes at arbeid med kvalitet ikke skal komme i tillegg til de daglige oppgavene, men bør være en integrert del av daglig drift. Utvikling og forbedring av kvalitet forutsetter derfor tydelige føringer, avklarte roller og god ledelse. Man må hele tiden forsøke å utnytte den beste tilgjengelige kunnskapen, undersøke om det som gjøres faktisk bidrar til å nå mål, og være forberedt på å endre kurs hvis målene ikke nåes. Hensynet til pasientenes behov og ønsker understrekes når tjenesten skal evalueres og forbedres.

Nasjonalt kunnskapssenteret for helsetjenesten beskriver modeller og metoder for systematisk forbedringsarbeid på sine nettsider (www.kunnskapssenteret.no). Forbedringsarbeid stiller krav til den kulturen som eksisterer på arbeidsplassen, det må være vilje og rom til kritisk refleksjon rundt egen og andres praksis. Videre er det helt nødvendig at det settes av tid og ressurser til arbeidet.

\subsection{Faglig forsvarlighet}

Bestemmelsen om at helsetjenesten skal være forsvarlig, er en rettslig standard som beskriver hvilke krav tjenesten må oppfylle ut fra de gitte forutsetninger og hva som kan anses å være gjeldende god praksis. Dette innebærer at standarden kan variere over tid, ved at det tilkommer ny kunnskap, ny teknologi eller endrede forutsetninger. Kravet om forsvarlighet innebærer også forsvarlig organisering av virksomheten.

Ledelsen har ansvaret for at driften er organisert på en måte som gjør det mulig for helsepersonellet å oppfylle plikten til forsvarlig yrkesutøvelse. Personalet må ha riktig kompetanse, ansvarsforhold må være avklart og forstått, og forsvarlige vaktordninger må være etablert.

Forsvarlighetskravet innenfor helse- og omsorgstjenesten i kommunen finnes i helse- og omsorgs tjenesteloven:

§ 4-1 Helse- og omsorgstjenester som tilbys eller ytes etter loven skal være forsvarlige. 
Kommunen skal tilrettelegge tjenestene slik at:

- den enkelte pasient eller bruker gis et helhetlig og koordinert helse- og omsorgstjenestetilbud

- den enkelte pasient eller bruker gis et verdig tjenestetilbud

- helse- og omsorgstjenesten og personell som utfører tjenestene blir i stand til å overholde sine lovpålagte plikter

- tilstrekkelig fagkompetanse sikres i tjenestene

Forsvarlighetskravet for spesialisthelsetjenesten er presisert i Spesialisthelsetjenesteloven. § 2-2: Helsetjenester som tilbys eller ytes i henhold til denne loven, skal være forsvarlige

Det vises også til Helsepersonelloven

§16: Virksomhet som yter helsehjelp, skal organiseres slik at helsepersonellet blir i stand til å overholde sine lovpålagte plikter.

\subsection{Internkontroll}

Enhver som yter helsetjenester skal ha internkontroll (system), uansett om virksomheten er drevet av kommune, fylkeskommune, stat, private eller andre. Hjemmelen om internkontroll i helsetjenesten finnes i Lov om statlig tilsyn med helsetjenesten $\S 3$ første ledd der det heter:

«Enhver som yter helsetjeneste skal etablere et internkontrollsystem for virksomheten og sørge for at virksomhet og tjenester planlegges, utføres og vedlikeholdes i samsvar med krav fastsatt i eller i medhold av lover og forskrifter»

Internkontroll handler om virksomhetens interne styring og egen kontroll. Hensikten med internkontroll er å oppnå kvalitetsforbedring som sikrer at virksomhetens oppgaver planlegges, organiseres, utføres og vedlikeholdes i samsvar med kravene i lovgivningen.

Helselovgivningen for øvrig inneholder bestemmelser som regulerer innhold $\mathrm{i}$ tjenesten og krav til styring og ledelse. Disse kravene må ses i sammenheng med kravene til internkontroll.

Ledelsen er faglig ansvarlig for alle sider ved virksomheten. I dette inngår ansvaret for å sikre at det blir utarbeidet og iverksatt nødvendige prosedyrer og påse at disse er kjent og fulgt, at nødvendig utstyr er tilgjengelig og at ansatte får nødvendig opplæring, faglig oppdatering og etter- og videreutdanning.

Helsedirektoratet har utgitt en veileder om internkontroll i sosial- og helsetjenesten: Hvordan holde orden i eget hus (IS-1183).

\subsection{Kvalitetsutvikling}

Internkontrollsystemet og kvalitetsforbedringen bør være sammenhengende. Kvalitetsutvikling i helse- og omsorgstjenestene er regulert av helse- og omsorgstjenestelovens $§ 4-2$ «Enhver som yter helse- og omsorgstjeneste etter loven her skal sørge for at virksomheten arbeider systematisk for kvalitetsforbedring og pasient- og brukersikkerhet» og i spesialisthelsetjenestelovens § 3-4 «Enhver som yter helsetjenester etter denne lov, skal sørge for at virksomheten arbeider systematisk for kvalitetsforbedring og pasientsikkerhet.»

En av de mest kjente modellene for kvalitetsforbedring er utviklet av William Edward Deming. Modellen kalles både Demings sirkel, PDSA-sirkelen (Plan, Do, Study, Act) og PUKK - sirkelen (Planlegge, Utføre, Kontrollere, Korrigere/standardisere). 
Langley et al. kombinerer Demings sirkel med tre grunnleggende spørsmål som man bør stille seg før en går i gang med forbedringstiltak. Modellen og de tre spørsmålene anbefales som verktøy i Nasjonal strategi for kvalitetsforbedring for sosial- og helsetjenesten (2005-2015).

Når et forbedringsområde er identifisert, gir metoden mulighet til rask utprøving av endringer i liten skala. Effekten av disse endringene evalueres før ytterligere endringer gjennomføres.

Erfaring fra praktisk bruk av Demings sirkel i systematisk forbedringsarbeid har vist et behov for å utdype og presisere trinnene i modellen ytterligere. Særlig gjelder dette forberedelsesfasen og betydningen av å følge opp, videreføre og spre forbedringene.

Dette har ført til at Modell for kvalitetsforbedring ble utviklet av Kunnskapssenteret i 2007, og videreutviklet i 2011 (figur 3).

Figur 3: Kunnskapssenterets modell for kvalitetsforbedring.

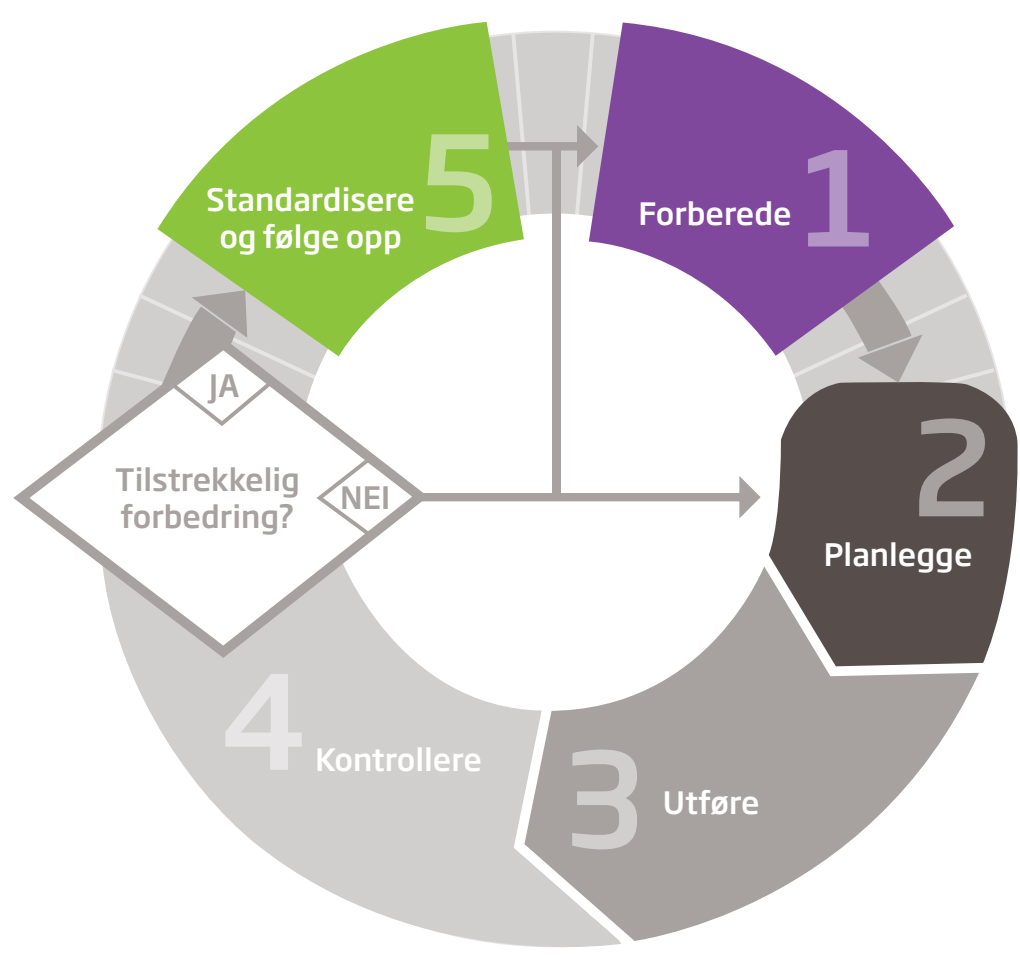

Det er vist at for å lykkes med forbedringsarbeid er det avgjørende å ha et system som:

- involverer pasienten og familien

- er forankret hos ledelsen og fagmiljøet

- skaper og bruker personlig engasjement hos de involverte

- utvikler en forbedringskultur hvor alle har to jobber; gjøre jobben og forbedre den

- utvikler en infrastruktur som fremmer forbedringsarbeidet

\subsection{Kunnskapsbasert praksis}

Det finnes flere definisjoner av kunnskapsbasert praksis og nye formuleringer har kommet til etter hvert som konseptet har utviklet seg. Begrepet «kunnskapsbasert» brukes ikke bare i klinisk praksis, men også om politikkutforming og innen andre samfunnsområder enn helse. Essensen i de ulike definisjonene er likevel den samme, nemlig integrering av ulike kunnskapskilder og kontekst i møte med pasienter eller i formulering av kunnskapsbaserte anbefalinger. 
Kunnskapsbasert praksis kan defineres slik:

Å utøve kunnskapsbasert praksis er å ta faglige avgjørelser basert på systematisk innhentet forskningsbasert kunnskap, erfaringsbasert kunnskap og pasientens ønsker og behov i den gitte situasjonen.

Kunnskapsgrunnlaget for faglige anbefalinger i dette rundskrivet er basert på forskningsbasert kunnskap, pasient/brukerkunnskap og erfaringsbasert kunnskap. Forskningsbasert kunnskap er hentet fra systematisk oversikter, brukerkunnskap er innhentet ved at pasienter har bidratt med sine erfaringer og synspunkt og erfaringsbasert kunnskap har kommet fra erfarne klinikere og fageksperter. Som vist i figuren under bidrar alle kildene til kunnskapsbasert praksis. I møte med den enkelte pasient er det sentralt at man kan vise til den beste tilgjengelig forskningsbaserte kunnskap og at denne brukes som støtte slik at pasienten kan gjøre et velinformert valg om behandling dersom det er hensiktsmessig og mulig.

\section{KONTEKST}

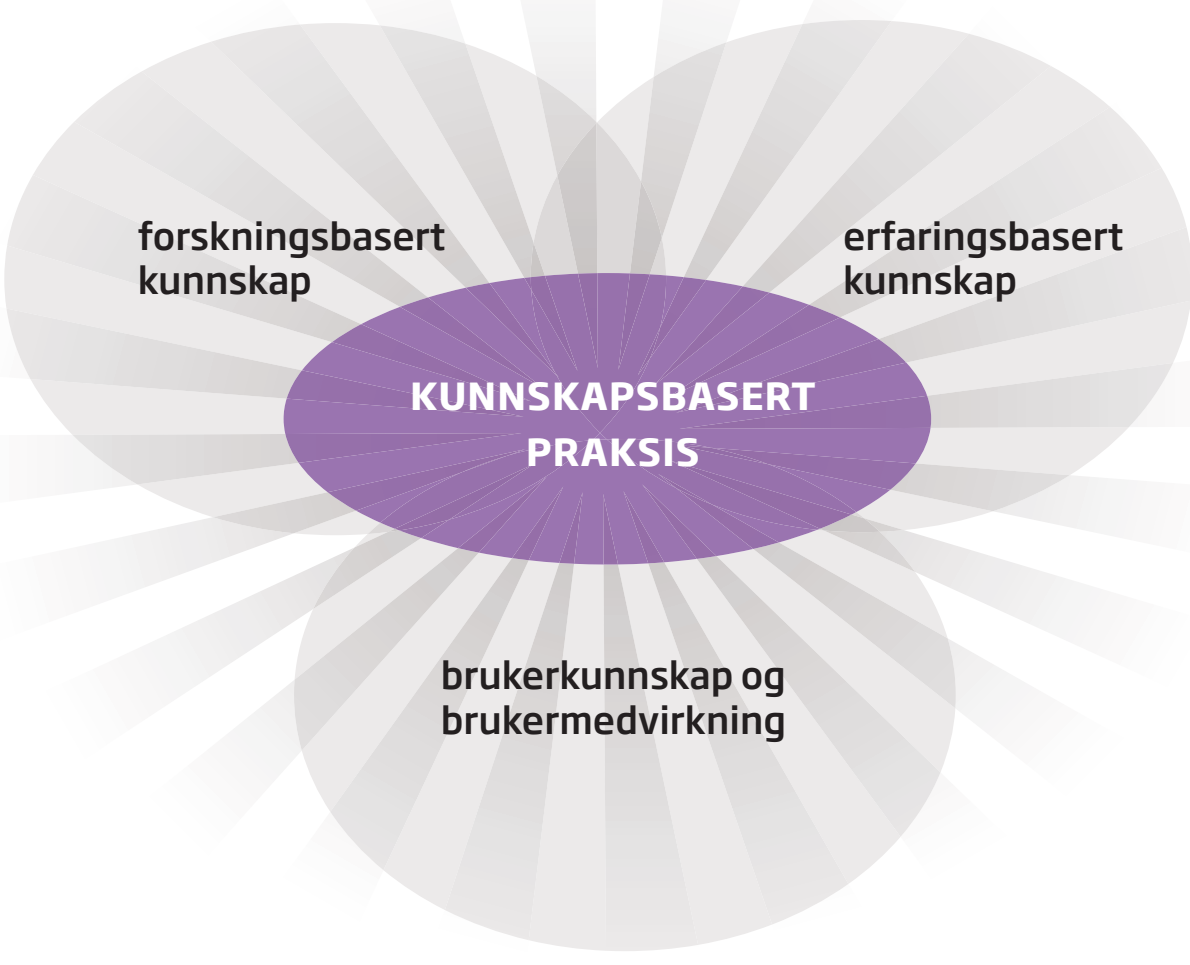

Forskningsbasert kunnskap bør være innsamlet, og vurdert på en eksplisitt og systematisk måte. For spørsmål om effekt av tiltak/behandling bør man først og fremst basere seg på systematiske oversikter. En systematisk oversikt er en oversiktsartikkel der forfatterne har brukt en systematisk og åpen framgangsmåte for å finne, vurdere og oppsummere flere enkeltstudier om samme emne. En god systematisk oversikt gir leseren oversikt over hva som finnes av forskning om et bestemt emne, og informasjon om kvaliteten på denne forskningen. Systematiske oversikter skal vise hele bildet og gjør den beste tilgjengelige forskningsbaserte kunnskapen lettere tilgjengelig.

Pasient-/brukerkunnskap og medvirkning Brukerne sørger for at deres perspektiv vurderes og synlig gjøres. De bidrar i vurderingene om tiltak/behandling medfører nytte, ulempe eller en ekstra byrde. Individperspektivet kan ivaretas ved å dokumentere fordeler og ulemper knyttet til ulike tilbud.

Erfaringsbasert kunnskap omfatter den fag- og sakkunnskap fagpersoner opparbeider seg gjennom klinisk praksis og skjønn. Erfaringen er individuell og fagpersoner kan utøve praksis forskjellig. 
For noen områder i dette rundskrivet har vi god forskningsbasert kunnskap og anbefalingene er basert på at disse tiltakene er dokumentert trygge og effektive.

For noen områder mangler det robust forskningsbasert kunnskap. Siden kunnskapsgrunnlaget er varierende har vi valgt å gi flere eksempler fra praksis med ønske om at det kan gi inspirasjon til praksisfeltet for å finne gode løsninger. 


\section{Litteraturliste, referanser}

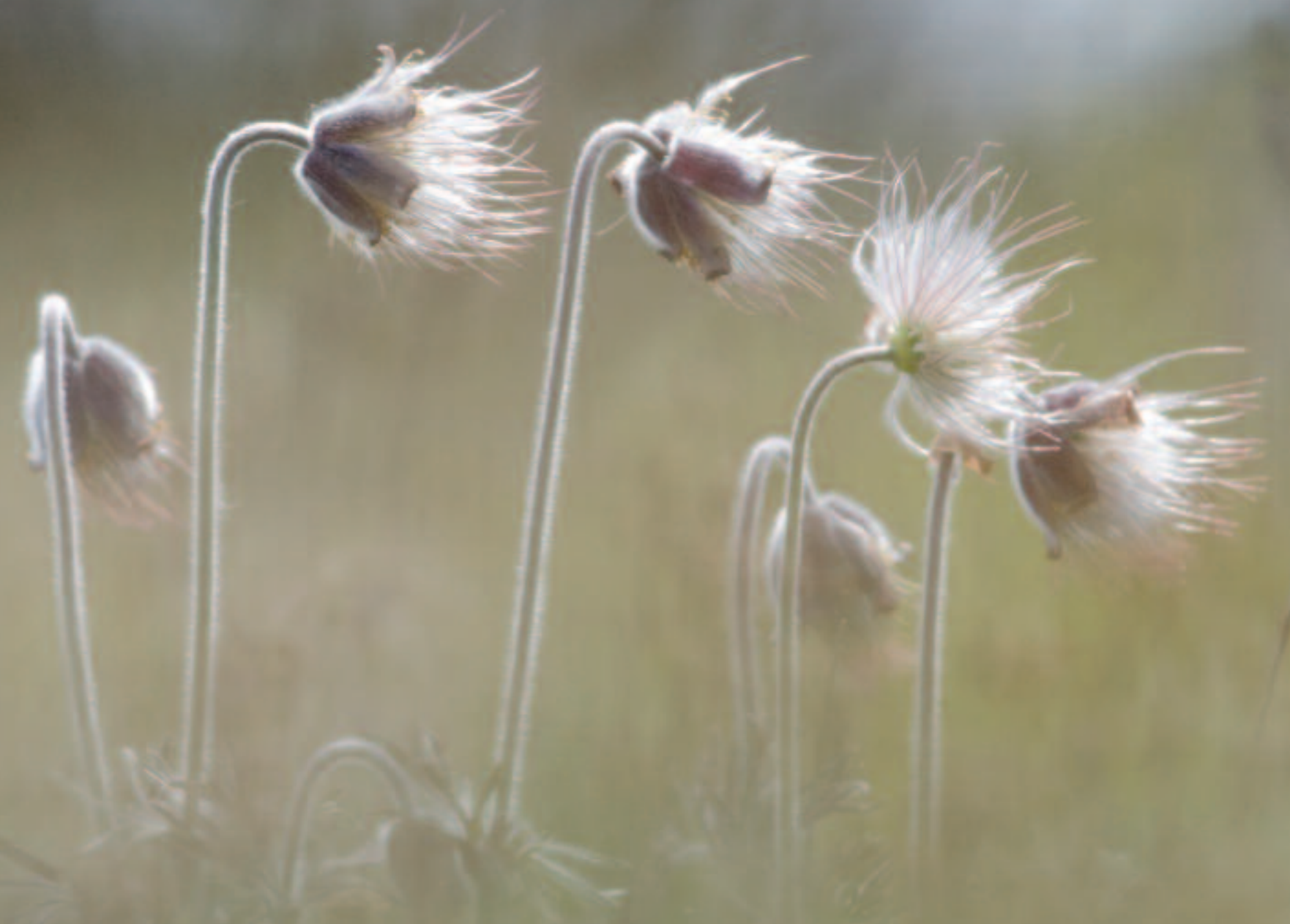


1. Royal Colleges of Physicians PaGP. Chronic fatigue syndrome; Report of a joint working group of the Royal Colleges of Physicians, Psychiatrists and General Practitioners. London, UK: Royal College of Physicians of London, Royal College of Psychiatrist and Royal College of General Practitioners; 1996.

2. Loge JH, Ekeberg 0, Kaasa S. Fatigue in the general Norwegian population: normative data and associations. Journal of psychosomatic research. 1998 Jul;45(1):53-65. PubMed PMID: 9720855.

3. Jason LA, Porter N, Hunnell J, Brown A, Rademaker A, Richman JA. A natural history study of chronic fatigue syndrome. Rehabilitation psychology. 2011 Feb;56(1):32-42. PubMed PMID: 21401284. Pubmed Central PMCID: 3171164.

4. Maes M, Twisk FN. Chronic fatigue syndrome: la bete noire of the Belgian health care system. Neuro endocrinology letters. 2009;30(3):300-11. PubMed PMID: 19855351. Epub 2009/10/27. eng.

5. Jason LA, Richman JA, Rademaker AW, Jordan KM, Plioplys AV, Taylor RR, et al. A community-based study of chronic fatigue syndrome. Archives of internal medicine. 1999 Oct 11;159(18):2129-37. PubMed PMID: 10527290.

6. Kato K, Sullivan PF, Evengard B, Pedersen NL. Premorbid predictors of chronic fatigue. Archives of general psychiatry. 2006 Nov;63(11):1267-72. PubMed PMID: 17088507.

7. Poeschla B, Strachan E, Dansie E, Buchwald DS, Afari N. Chronic fatigue and personality: a twin study of causal pathways and shared liabilities. Annals of behavioral medicine : a publication of the Society of Behavioral Medicine. 2013 Jun;45(3):289-98. PubMed PMID: 23361410. Pubmed Central PMCID: 3643988.

8. Fukuda S, Kuratsune H, Tajima S, Takashima S, Yamagutchi K, Nishizawa Y, et al. Premorbid personality in chronic fatigue syndrome as determined by the Temperament and Character Inventory. Comprehensive psychiatry. 2010 Jan-Feb;51(1):78-85. PubMed PMID: 19932830.

9. Taylor RR, Jason LA. Sexual abuse, physical abuse, chronic fatigue, and chronic fatigue syndrome: a community-based study. The Journal of nervous and mental disease. 2001 Oct;189(10):709-15. PubMed PMID: 11708672.

10. Heim C, Wagner D, Maloney E, Papanicolaou DA, Solomon L, Jones JF, et al. Early adverse experience and risk for chronic fatigue syndrome: results from a population-based study. Archives of general psychiatry. 2006 Nov;63(11):1258-66. PubMed PMID: 17088506.

11. Dansie E, Heppner P, Furberg H, Goldberg J, Buchwald D, Afari N. The Comorbidity of Self-Reported Chronic Fatigue Syndrome, Posttraumatic Stress Disorder, and Traumatic Symptoms. Psychosomatics. 2012 May;53(3):250-7. PubMed PMID: 22296866. eng.

12. Salit IE. Precipitating factors for the chronic fatigue syndrome. Journal of psychiatric research. 1997 Jan-Feb;31(1):59-65. PubMed PMID: 9201648.

13. Hatcher S, House A. Life events, difficulties and dilemmas in the onset of chronic fatigue syndrome: a case-control study. Psychological medicine. 20030ct;33(7):1185-92. PubMed PMID: 14580073.

14. Smith AK, Fang H, Whistler T, Unger ER, Rajeevan MS. Convergent genomic studies identify association of GRIK2 and NPAS2 with chronic fatigue syndrome. Neuropsychobiology. 2011;64(4):183-94. PubMed PMID: 21912186.

15. Albright F, Light K, Light A, Bateman L, Cannon-Albright LA. Evidence for a heritable predisposition to Chronic Fatigue Syndrome. BMC Neurology. 2011;11:62. PubMed PMID: 21619629. Pubmed Central PMCID: PMC2654901. eng.

16. Buchwald DS, Rea TD, Katon WJ, Russo JE, Ashley RL. Acute infectious mononucleosis: characteristics of patients who report failure to recover. The American journal of medicine. 2000 Nov;109(7):531-7. PubMed PMID: 11063953.

17. White PD, Thomas JM, Amess J, Crawford DH, Grover SA, Kangro HO, et al. Incidence, risk and prognosis of acute and chronic fatigue syndromes and psychiatric disorders after glandular fever. The British journal of psychiatry : the journal of mental science. 1998 Dec;173:475-81. PubMed PMID: 9926075. Epub 1999/02/02. eng.

18. Katz BZ, Jason LA. Chronic fatigue syndrome following infections in adolescents. Current opinion in pediatrics. 2013 Feb;25(1):95-102. PubMed PMID: 23263024. Epub 2012/12/25. eng.

19. K Mr, Hanevik K, Rivenes AC, JE Bd, Naess H, Stubhaug B, et al. Chronic fatigue syndrome 5 years after giardiasis: differential diagnoses, characteristics and natural course. BMC Gastroenterology. 2013;13:28. PubMed PMID: 23399438. eng.

20. Lombardi VC, Ruscetti FW, Das Gupta J, Pfost MA, Hagen KS, Peterson DL, et al. Detection of an infectious retrovirus, XMRV, in blood cells of patients with chronic fatigue syndrome. Science. 2009 Oct 23;326(5952):585-9. PubMed PMID: 19815723.

21. Alter HJ, Mikovits JA, Switzer WM, Ruscetti FW, Lo SC, Klimas N, et al. A Multicenter Blinded Analysis Indicates No Association between Chronic Fatigue Syndrome/Myalgic Encephalomyelitis and either Xenotropic Murine Leukemia Virus-Related Virus or Polytropic Murine Leukemia Virus. mBio. 2012 Sep-Oct;3(5). PubMed PMID: 22991430. Pubmed Central PMCID: PMC3598369. eng. 
22. Fletcher MA, Zeng XR, Barnes Z, Levis S, Klimas NG. Plasma cytokines in women with chronic fatigue syndrome. Journal of translational medicine. 2009;7:96. PubMed PMID: 19909538. Pubmed Central PMCID: 2779802.

23. Brenu EW, van Driel ML, Staines DR, Ashton KJ, Hardcastle SL, Keane J, et al. Longitudinal investigation of natural killer cells and cytokines in chronic fatigue syndrome/myalgic encephalomyelitis. Journal of translational medicine. 2012;10:88. PubMed PMID: 22571715. eng.

24. Broderick G, Katz BZ, Fernandes H, Fletcher MA, Klimas N, Smith FA, et al. Cytokine expression profiles of immune imbalance in post-mononucleosis chronic fatigue. Journal of translational medicine. 2012;10:191. PubMed PMID: 22973830. Pubmed Central PMCID: PMC3464733. eng.

25. Curriu M, Carrillo J, Massanella M, Rigau J, Alegre J, Puig J, et al. Screening NK-, B- and T-cell phenotype and function in patients suffering from Chronic Fatigue Syndrome. Journal of translational medicine. 2013;11:68. PubMed PMID: 23514202. Pubmed Central PMCID: PMC3480896. eng.

26. Brenu EW, van Driel ML, Staines DR, Ashton KJ, Ramos SB, Keane J, et al. Immunological abnormalities as potential biomarkers in Chronic Fatigue Syndrome/Myalgic Encephalomyelitis. Journal of translational medicine. 2011;9:81. PubMed PMID: 21619669. eng.

27. Fluge O, Bruland O, Risa K, Storstein A, Kristoffersen EK, Sapkota D, et al. Benefit from B-lymphocyte depletion using the antiCD20 antibody rituximab in chronic fatigue syndrome. A double-blind and placebo-controlled study. PloS one. 2011;6(10):e26358. PubMed PMID: 22039471. Pubmed Central PMCID: 3198463.

28. Wyller VB, Barbieri R, Saul JP. Blood pressure variability and closed-loop baroreflex assessment in adolescent chronic fatigue syndrome during supine rest and orthostatic stress. European journal of applied physiology. 2011 Mar;111(3):497-507. PubMed PMID: 20890710. Pubmed Central PMCID: 3037975.

29. Lewis I, Pairman J, Spickett G, Newton JL. Clinical characteristics of a novel subgroup of chronic fatigue syndrome patients with postural orthostatic tachycardia syndrome. Journal of internal medicine. 2013 May;273(5):501-10. PubMed PMID: 23206180.

30. Okamoto LE, Raj SR, Peltier A, Gamboa A, Shibao C, Diedrich A, et al. Neurohumoral and haemodynamic profile in postural tachycardia and chronic fatigue syndromes. Clinical science (London, England : 1979). 2012 Feb;122(4):183-92. PubMed PMID: 21906029. Pubmed Central PMCID: PMC3203411. Epub 2011/09/13. eng.

31. Wyller VB, Eriksen HR, Malterud K. Can sustained arousal explain the Chronic Fatigue Syndrome? Behavioral and brain functions : BBF. 2009;5:10. PubMed PMID: 19236717. Pubmed Central PMCID: 2654901.

32. Kawli T, He F, Tan MW. It takes nerves to fight infections: insights on neuro-immune interactions from C. elegans. Disease models \& mechanisms. 2010 Nov-Dec;3(11-12):721-31. PubMed PMID: 20829562. Pubmed Central PMCID: 2965399.

33. Van Den Eede F, Moorkens G, Van Houdenhove B, Cosyns P, Claes SJ. Hypothalamic-pituitary-adrenal axis function in chronic fatigue syndrome. Neuropsychobiology. 2007;55(2):112-20. PubMed PMID: 17596739. Epub 2007/06/29. eng.

34. Papadopoulos AS, Cleare AJ. Hypothalamic-pituitary-adrenal axis dysfunction in chronic fatigue syndrome. Nature reviews Endocrinology. 2012 Jan;8(1):22-32. PubMed PMID: 21946893. Epub 2011/09/29. eng.

35. Light A, Bateman L, Jo D, Hughen RW, VanHaitsma T, White A, et al. Gene expression alterations at baseline and following moderate exercise in patients with Chronic Fatigue Syndrome, and Fibromyalgia Syndrome. Journal of internal medicine. 2012 Jan;271(1):64-81. PubMed PMID: 21615807. Pubmed Central PMCID: PMC3256093. eng.

36. White AT, Light AR, Hughen RW, VanHaitsma TA, Light KC. Differences in metabolite-detecting, adrenergic, and immune gene expression following moderate exercise in chronic fatigue syndrome, multiple sclerosis and healthy controls. Psychosomatic Medicine. 2012 Jan;74(1):46-54. PubMed PMID: 22210239. eng.

37. Barnden LR, Crouch B, Kwiatek R, Burnet R, Mernone A, Chryssidis S, et al. A brain MRI study of chronic fatigue syndrome: evidence of brainstem dysfunction and altered homeostasis. NMR in biomedicine. 2011 Dec;24(10):1302-12. PubMed PMID: 21560176. Epub 2011/05/12. eng.

38. Mizuno K, Watanabe Y. Neurocognitive impairment in childhood chronic fatigue syndrome. Frontiers in physiology. 2013;4:87. PubMed PMID: 23626579. Pubmed Central PMCID: PMC3630366. Epub 2013/04/30. eng.

39. Ocon AJ. Caught in the thickness of brain fog: exploring the cognitive symptoms of Chronic Fatigue Syndrome. Frontiers in physiology. 2013;4:63. PubMed PMID: 23576989. Pubmed Central PMCID: PMC3617392. Epub 2013/04/12. eng.

40. Puri BK, Jakeman PM, Agour M, Gunatilake KD, Fernando KA, Gurusinghe Al, et al. Regional grey and white matter volumetric changes in myalgic encephalomyelitis (chronic fatigue syndrome): a voxel-based morphometry 3 T MRI study. The British journal of radiology. 2012 Jul;85(1015):e270-3. PubMed PMID: 22128128. Pubmed Central PMCID: PMC3474083. Epub 2011/12/01. eng.

41. Natelson BH. Brain dysfunction as one cause of CFS symptoms including difficulty with attention and concentration. Frontiers in physiology. 2013;4:109. PubMed PMID: 23730290. Pubmed Central PMCID: 3657628. 
42. Gur A, Oktayoglu P. Central nervous system abnormalities in fibromyalgia and chronic fatigue syndrome: new concepts in treatment. Current pharmaceutical design. 2008;14(13):1274-94. PubMed PMID: 18537652. Epub 2008/06/10. eng.

43. Biswal B, Kunwar P, Natelson BH. Cerebral blood flow is reduced in chronic fatigue syndrome as assessed by arterial spin labeling. Journal of the neurological sciences. 2011 Feb 15;301(1-2):9-11. PubMed PMID: 21167506.

Pubmed Central PMCID: PMC3139492. Epub 2010/12/21. eng.

44. Yunus MB. Fibromyalgia and overlapping disorders: the unifying concept of central sensitivity syndromes. Seminars in arthritis and rheumatism. 2007 Jun;36(6):339-56. PubMed PMID: 17350675. Epub 2007/03/14. eng.

45. Kato K, Sullivan PF, Evengard B, Pedersen NL. A population-based twin study of functional somatic syndromes. Psychological medicine. 2009 Mar;39(3):497-505. PubMed PMID: 18578896. Epub 2008/06/27. eng.

46. Nijs J, Meeus M, Van Oosterwijck J, Ickmans K, Moorkens G, Hans G, et al. In the mind or in the brain? Scientific evidence for central sensitisation in chronic fatigue syndrome. European journal of clinical investigation. 2012 Feb;42(2):203-12. PubMed PMID: 21793823.

47. Bould H, Collin SM, Lewis G, Rimes K, Crawley E. Depression in paediatric chronic fatigue syndrome. Archives of disease in childhood. 2013 Jun;98(6):425-8. PubMed PMID: 23619200. Epub 2013/04/27. eng.

48. Crawley E, Hunt L, Stallard P. Anxiety in children with CFS/ME. European child \& adolescent psychiatry. 2009 Nov;18(11):683-9. PubMed PMID: 19452195. Epub 2009/05/20. eng.

49. Harvey SB, Wadsworth M, Wessely S, Hotopf M. The relationship between prior psychiatric disorder and chronic fatigue: evidence from a national birth cohort study. Psychological medicine. 2008 Jul;38(7):933-40. PubMed PMID: 17976252. Pubmed Central PMCID: PMC3196526. Epub 2007/11/03. eng.

50. Sullivan PF, Pedersen NL, Jacks A, Evengard B. Chronic fatigue in a population sample: definitions and heterogeneity. Psychological medicine. 2005 Sep;35(9):1337-48. PubMed PMID: 16168156.

51. Chapenko S, Krumina A, Logina I, Rasa S, Chistjakovs M, Sultanova A, et al. Association of Active Human Herpesvirus-6, -7 and Parvovirus B19 Infection with Clinical Outcomes in Patients with Myalgic Encephalomyelitis/Chronic Fatigue Syndrome. Advances in Virology. 2012;2012. PubMed PMID: 22927850. eng.

52. Burbelo PD, Bayat A, Wagner J, Nutman TB, Baraniuk JN, ladarola MJ. No serological evidence for a role of HHV-6 infection in chronic fatigue syndrome. American Journal of Translational Research. 2012;4(4):443-51. PubMed PMID: 23145212. eng.

53. Oakes B, Hoagland-Henefield M, Komaroff AL, Erickson JL, Huber BT. Human endogenous retrovirus-K18 superantigen expression and human herpesvirus- 6 and human herpesvirus-7 viral loads in chronic fatigue patients. Clinical infectious diseases : an official publication of the Infectious Diseases Society of America. 2013 May;56(10):1394-400. PubMed PMID: 23408682. Epub 2013/02/15. eng.

54. Kempke S, Luyten P, Van Houdenhove B, Goossens L, Bekaert P, Van Wambeke P. Self-esteem mediates the relationship between maladaptive perfectionism and depression in chronic fatigue syndrome. Clinical rheumatology. 2011 Dec;30(12):1543-8. PubMed PMID: 21584732.

55. Luyten P, Kempke S, Van Wambeke P, Claes S, Blatt SJ, Van Houdenhove B. Self-critical perfectionism, stress generation, and stress sensitivity in patients with chronic fatigue syndrome: relationship with severity of depression. Psychiatry. 2011 Spring;74(1):21-30. PubMed PMID: 21463167.

56. Kempke S, Van Houdenhove B, Luyten P, Goossens L, Bekaert P, Van Wambeke P. Unraveling the role of perfectionism in chronic fatigue syndrome: is there a distinction between adaptive and maladaptive perfectionism? Psychiatry research. 2011 Apr 30;186(2-3):373-7. PubMed PMID: 20961622.

57. Knoop H, Prins JB, Moss-Morris R, Bleijenberg G. The central role of cognitive processes in the perpetuation of chronic fatigue syndrome. Journal of psychosomatic research. 2010 May;68(5):489-94. PubMed PMID: 20403509.

58. Valero S, Saez-Francas N, Calvo N, Alegre J, Casas M. The role of neuroticism, perfectionism and depression in chronic fatigue syndrome. A structural equation modeling approach. Comprehensive psychiatry. 2013 Jun 4. PubMed PMID: 23759150. Epub 2013/06/14. Eng.

59. Luyten P, Van Houdenhove B, Pae CU, Kempke S, Van Wambeke P. Treatment of Chronic Fatigue Syndrome: Findings, Principles and Strategies. Psychiatry Investigation. 2008 Dec;5(4):209-12. PubMed PMID: 20046339. eng.

60. Schmaling KB, Fiedelak JI, Katon WJ, Bader JO, Buchwald DS. Prospective study of the prognosis of unexplained chronic fatigue in a clinic-based cohort. Psychosomatic Medicine. 2003 Nov-Dec;65(6):1047-54. PubMed PMID: 14645784. Epub 2003/12/04. eng.

61. Hill NF, Tiersky LA, Scavalla VR, Lavietes M, Natelson BH. Natural history of severe chronic fatigue syndrome. Archives of physical medicine and rehabilitation. 1999 Sep;80(9):1090-4. PubMed PMID: 10489014. Epub 1999/09/17. eng. 
62. Brown MM, Bell DS, Jason LA, Christos C, Bell DE. Understanding long-term outcomes of chronic fatigue syndrome. Journal of clinical psychology. 2012 Sep;68(9):1028-35. PubMed PMID: 22753044.

63. Torres-Harding SR, Jason LA, Taylor RR. Fatigue severity, attributions, medical utilization, and symptoms in persons with chronic fatigue. Journal of behavioral medicine. 2002 Apr;25(2):99-113. PubMed PMID: 11977439.

64. Joyce J, Hotopf M, Wessely S. The prognosis of chronic fatigue and chronic fatigue syndrome: a systematic review. QJM : monthly journal of the Association of Physicians. 1997 Mar;90(3):223-33. PubMed PMID: 9093600.

65. Tiersky LA, DeLuca J, Hill N, Dhar SK, Johnson SK, Lange G, et al. Longitudinal assessment of neuropsychological functioning, psychiatric status, functional disability and employment status in chronic fatigue syndrome. Applied neuropsychology. 2001;8(1):41-50. PubMed PMID: 11388123.

66. Lim BR, Tan SY, Zheng YP, Lin KM, Park BC, Turk AA. Psychosocial factors in chronic fatigue syndrome among Chinese Americans: a longitudinal community-based study. Transcultural psychiatry. 2003 Sep;40(3):429-41. PubMed PMID: 14649853.

67. Rangel L, Garralda ME, Levin M, Roberts H. The course of severe chronic fatigue syndrome in childhood. Journal of the Royal Society of Medicine. 2000 Mar;93(3):129-34. PubMed PMID: 10741312. eng.

68. Nacul LC, Lacerda EM, Campion P, Pheby D, Drachler Mde L, Leite JC, et al. The functional status and well being of people with myalgic encephalomyelitis/chronic fatigue syndrome and their carers. BMC public health. 2011;11:402. PubMed PMID: 21619607. Pubmed Central PMCID: 3123211.

69. Komaroff AL, Fagioli LR, Doolittle TH, Gandek B, Gleit MA, Guerriero RT, et al. Health status in patients with chronic fatigue syndrome and in general population and disease comparison groups. The American journal of medicine. 1996 Sep;101(3):281-90. PubMed PMID: 8873490. Epub 1996/09/01. eng.

70. Carruthers BM, van de Sande MI, De Meirleir KL, Klimas NG, Broderick G, Mitchell T, et al. Myalgic encephalomyelitis: International Consensus Criteria. Journal of internal medicine. 2011 Oct;270(4):327-38. PubMed PMID: 21777306. Pubmed Central PMCID: 3427890.

71. Meeus M, van Eupen I, van Baarle E, De Boeck V, Luyckx A, Kos D, et al. Symptom fluctuations and daily physical activity in patients with chronic fatigue syndrome: a case-control study. Archives of physical medicine and rehabilitation. 2011 Nov;92(11):1820-6. PubMed PMID: 22032215.

72. Johnston S, Brenu EW, Staines D, Marshall-Gradisnik S. The prevalence of chronic fatigue syndrome/ myalgic encephalomyelitis: a meta-analysis. Clinical epidemiology. 2013;5:105-10. PubMed PMID: 23576883. Pubmed Central PMCID: 3616604.

73. Nacul LC, Lacerda EM, Pheby D, Campion P, Molokhia M, Fayyaz S, et al. Prevalence of myalgic encephalomyelitis/chronic fatigue syndrome (ME/CFS) in three regions of England: a repeated cross-sectional study in primary care. BMC medicine. 2011;9:91. PubMed PMID: 21794183. Pubmed Central PMCID: 3170215.

74. Chalder T, Goodman R, Wessely S, Hotopf M, Meltzer H. Epidemiology of chronic fatigue syndrome and self reported myalgic encephalomyelitis in 5-15 year olds: cross sectional study. Bmj. 2003 Sep 20;327(7416):654-5. PubMed PMID: 14500438. Pubmed Central PMCID: 196393.

75. Nijhof SL, Maijer K, Bleijenberg G, Uiterwaal CS, Kimpen JL, van de Putte EM. Adolescent chronic fatigue syndrome: prevalence, incidence, and morbidity. Pediatrics. 2011 May;127(5):e1169-75. PubMed PMID: 21502228.

76. Sarzi-Puttini P, Atzeni F, Di Franco M, Buskila D, Alciati A, Giacomelli C, et al. Dysfunctional syndromes and fibromyalgia: a 2012 critical digest. Clinical and experimental rheumatology. 2012 Nov-Dec;30(6 Suppl 74):143-51. PubMed PMID: 23261014. Epub 2013/02/27. eng.

77. Henningsen P, Zipfel S, Herzog W. Management of functional somatic syndromes. Lancet. 2007 Mar 17;369(9565):946-55. PubMed PMID: 17368156.

78. Fink P, Schroder A. One single diagnosis, bodily distress syndrome, succeeded to capture 10 diagnostic categories of functional somatic syndromes and somatoform disorders. Journal of psychosomatic research. 2010 May;68(5):415-26. PubMed PMID: 20403500. Epub 2010/04/21. eng.

79. Kanaan RA, Lepine JP, Wessely SC. The association or otherwise of the functional somatic syndromes. Psychosomatic Medicine. 2007 Dec;69(9):855-9. PubMed PMID: 18040094. Pubmed Central PMCID: PMC2575798. Epub 2007/11/28. eng.

80. Ljostad U, Mygland A. Chronic Lyme; diagnostic and therapeutic challenges. Acta neurologica Scandinavica Supplementum. 2013 (196):38-47. PubMed PMID: 23190290.

81. Afari N, Buchwald D. Chronic fatigue syndrome: a review. The American journal of psychiatry. 2003 Feb;160(2):221-36. PubMed PMID: 12562565.

82. Wyller VB, Helland IB. Relationship between autonomic cardiovascular control, case definition, clinical symptoms, and functional disability in adolescent chronic fatigue syndrome: an exploratory study. BioPsychoSocial medicine. 2013;7(1):5. PubMed PMID: 23388153. Pubmed Central PMCID: 3570350. 
83. Fukuda K, Straus SE, Hickie I, Sharpe MC, Dobbins JG, Komaroff A. The chronic fatigue syndrome: a comprehensive approach to its definition and study. International Chronic Fatigue Syndrome Study Group. Annals of internal medicine. 1994 Dec 15;121(12):953-9. PubMed PMID: 7978722.

84. Carruthers BM, Jain AK, De Meirleir KL, al. e. Myalgic encephalomyelitis/ chronic fatigue syndrome: clinical working case definition, diagnostic and treatment protocols. J Chronic Fatigue Syndr. 2003;11:7-116.

85. Jason LA, Bell DS, Rowe K, Van Hoof ELS, Jordan K, Lapp C, et al. A Pediatric Case Definition for Myalgic Encephalomyelitis and Chronic Fatigue Syndrome. Journal of Chronic Fatigue Syndrome. 2006;13(2/3):1-44.

86. Hofmann SG, Asnaani A, Vonk IJ, Sawyer AT, Fang A. The Efficacy of Cognitive Behavioral Therapy: A Review of Meta-analyses. Cognitive therapy and research. 2012 Oct 1;36(5):427-40. PubMed PMID: 23459093. eng.

87. Evers AW, Kraaimaat FW, van Riel PL, de Jong AJ. Tailored cognitive-behavioral therapy in early rheumatoid arthritis for patients at risk: a randomized controlled trial. Pain. 2002 Nov;100(1-2):141-53. PubMed PMID: 12435467.

88. Hewlett S, Ambler N, Almeida C, Cliss A, Hammond A, Kitchen K, et al. Self-management of fatigue in rheumatoid arthritis: a randomised controlled trial of group cognitive-behavioural therapy. Annals of the rheumatic diseases. 2011 Jun;70(6):1060-7. PubMed PMID: 21540202. Pubmed Central PMCID: 3086034.

89. Nijhof SL, Bleijenberg G, Uiterwaal CS, Kimpen JL, van de Putte EM. Effectiveness of internet-based cognitive behavioural treatment for adolescents with chronic fatigue syndrome (FITNET): a randomised controlled trial. Lancet. $2012 \mathrm{Apr}$ 14;379(9824):1412-8. PubMed PMID: 22385683.

90. Edmonds M, McGuire H, Price J. Exercise therapy for chronic fatigue syndrome. Cochrane database of systematic reviews. 2004 (3):CD003200. PubMed PMID: 15266475.

91. White PD, Goldsmith KA, Johnson AL, Potts L, Walwyn R, DeCesare JC, et al. Comparison of adaptive pacing therapy, cognitive behaviour therapy, graded exercise therapy, and specialist medical care for chronic fatigue syndrome (PACE): a randomised trial. Lancet. 2011 Mar 5;377(9768):823-36. PubMed PMID: 21334061. Pubmed Central PMCID: 3065633.

92. Larun L, Malterud K. Finding the right balance of physical activity: a focus group study about experiences among patients with chronic fatigue syndrome. Patient education and counseling. 2011 May;83(2):222-6. PubMed PMID: 20580520.

93. Wyller VB. Kronisk utmattelsessyndrom hos barn og ungdommer. Myalgisk encafalopati (CFS/ME).2008. Available from: http://www.os/o-universitetssykehus.no/SiteCollectionDocuments/Om oss/Avdelinger/Kvinne- og barneklinikken/Utmattelssyndrom barn og ungdom.pdf.

94. Goudsmit EM, Nijs J, Jason LA, Wallman KE. Pacing as a strategy to improve energy management in myalgic encephalomyelitis/chronic fatigue syndrome: a consensus document. Disability and rehabilitation. 2012;34(13):1140-7. PubMed PMID: 22181560.

95. Jason LA, Brown M, Brown A, Evans M, Flores S, Grant-Holler E, et al. Energy Conservation/Envelope Theory Interventions to Help Patients with Myalgic Encephalomyelitis/Chronic Fatigue Syndrome. Fatigue. 2013 Jan 14;1(1-2):27-42. PubMed PMID: 23504301. Pubmed Central PMCID: 3596172.

96. Brown M, Khorana N, Jason LA. The Role of Changes in Activity as a Function of Perceived Available and Expended Energy in Non-Pharmacological Treatment Outcomes for ME/CFS. Journal of clinical psychology. 2011 Mar;67(3):253-60. PubMed PMID: 21254053. eng.

97. McCrone P, Sharpe M, Chalder T, Knapp M, Johnson AL, Goldsmith KA, et al. Adaptive pacing, cognitive behaviour therapy, graded exercise, and specialist medical care for chronic fatigue syndrome: a cost-effectiveness analysis. PloS one. 2012;7(8):e40808. PubMed PMID: 22870204. Pubmed Central PMCID: PMC3411573. Epub 2012/08/08. eng.

98. Burgess M, Chalder T. Adolescents with severe chronic fatigue syndrome can make a full recovery. BMJ case reports. $2011 ; 2011$. PubMed PMID: 22696706. Pubmed Central PMCID: 3091076.

99. Nijs J, Crombez G, Meeus M, Knoop H, Damme SV, Cauwenbergh V, et al. Pain in patients with chronic fatigue syndrome: time for specific pain treatment? Pain physician. 2012 Sep-Oct;15(5):E677-86. PubMed PMID: 22996861. Epub 2012/09/22. eng.

100. Nijs J, Paul van Wilgen C, Van Oosterwijck J, van Ittersum M, Meeus M. How to explain central sensitization to patients with 'unexplained' chronic musculoskeletal pain: practice guidelines. Manual therapy. 2011 0ct;16(5):413-8. PubMed PMID: 21632273.

101. Jackson ML, Bruck D. Sleep abnormalities in chronic fatigue syndrome/myalgic encephalomyelitis: a review. Journal of clinical sleep medicine : JCSM : official publication of the American Academy of Sleep Medicine. 2012 Dec 15;8(6):719-28. PubMed PMID: 23243408. Pubmed Central PMCID: PMC3501671. Epub 2012/12/18. eng.

102. Festvåg L, Sparre M, Opheim A, Stanghelle JK. For utmattet til å trene? Qigong i behandlingen av personer med Myalgisk Encefalopati. Fysioterapeuten. 2006 (1):14-8. 
103. Alraek T, Lee MS, Choi TY, Cao H, Liu J. Complementary and alternative medicine for patients with chronic fatigue syndrome: a systematic review. BMC complementary and alternative medicine. 2011;11:87. PubMed PMID: 21982120. Pubmed Central PMCID: PMC3201900. Epub 2011/10/11. eng.

104. Ho RT, Chan JS, Wang CW, Lau BW, So KF, Yuen LP, et al. A randomized controlled trial of qigong exercise on fatigue symptoms, functioning, and telomerase activity in persons with chronic fatigue or chronic fatigue syndrome. Annals of behavioral medicine : a publication of the Society of Behavioral Medicine. 2012 Oct;44(2):160-70. PubMed PMID: 22736201. Pubmed Central PMCID: PMC3442161. Epub 2012/06/28. eng.

105. Shin Yl, Lee MS. Qi therapy (external qigong) for chronic fatigue syndrome: case studies. The American journal of Chinese medicine. 2005;33(1):139-41. PubMed PMID: 15844841. Epub 2005/04/23. eng.

106. Knight SJ, Scheinberg A, Harvey AR. Interventions in Pediatric Chronic Fatigue Syndrome/Myalgic Encephalomyelitis: A Systematic Review. The Journal of adolescent health : official publication of the Society for Adolescent Medicine. 2013 May 1. PubMed PMID: 23643337.

107. Sidsel Kreyber, http://me-foreningen.com/meforeningen/innhold/div/2012/06/12grunnregler-ved-ME-revidert-okt-2005.pdf (Mai 2015) 


\section{Vedlegg}

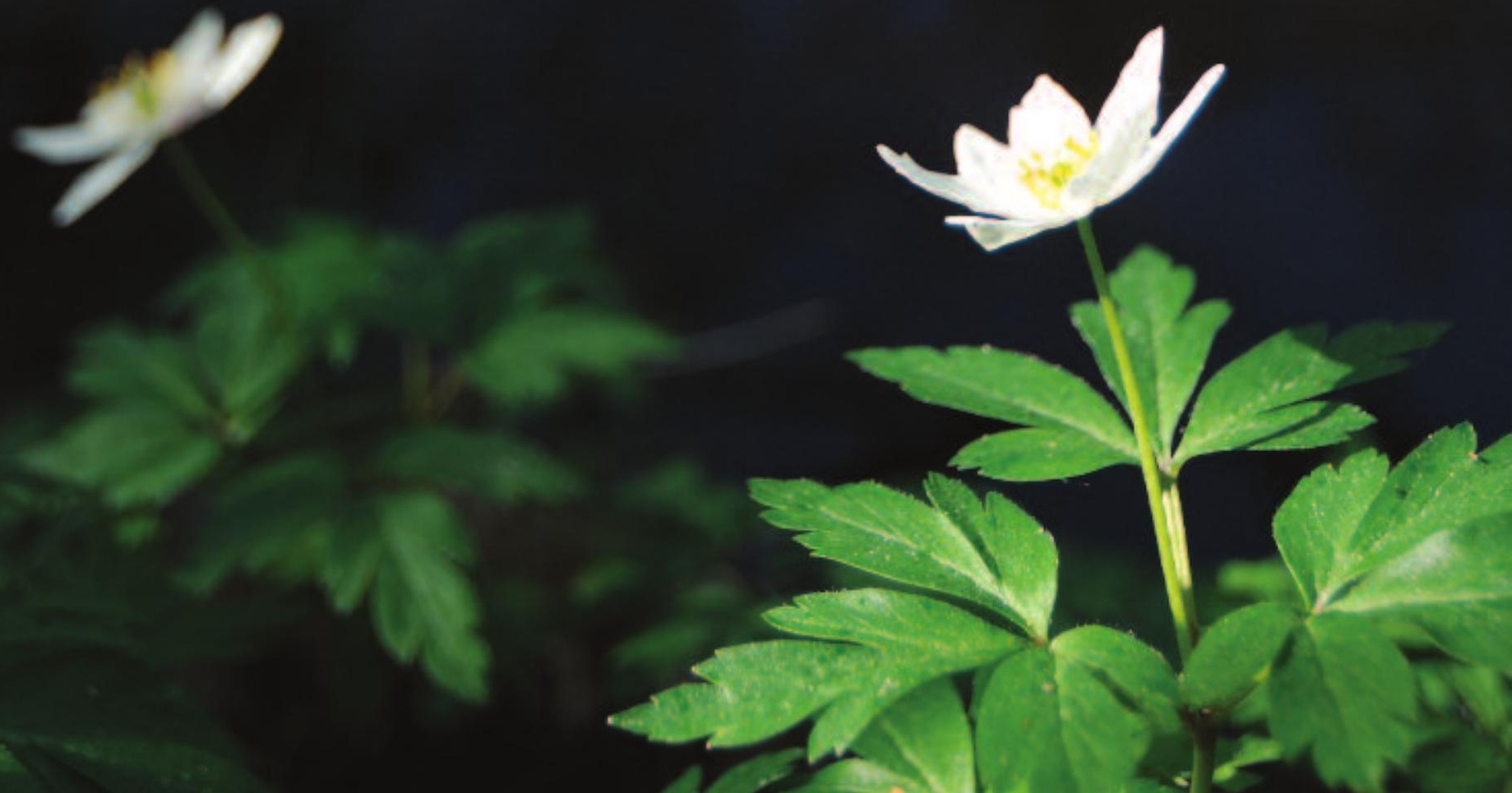




\section{Vedlegg 1}

\section{Utredningsskjema etter Canada-kriteriene 2003}

Kriteriene 1), 2), 3), 4) og 7) må være tilstede; i tillegg to eller flere symptomer fra 5) og ett eller flere symptomer fra 6)

1. Utmattelse (fysisk og psykisk) som reduserer aktivitetsnivået med $50 \%$ eller mer

\section{Anstrengelsesutløst sykdomsfølelse og/eller utmattelse.}
a. Unaturlig tap av fysisk eller psykisk utholdenhet. Rask muskulær og mental/kognitiv trettbarhet.
b. Sykdomsfølelse og/eller utmattelse etter anstrengelse
c. Forverring av andre assosierte symptomer etter anstrengelse
d. Forlenget restitusjonstid, ofte 24 timer eller mer

3. Søvnforstyrrelser som forstyrret døgnrytme, innsovningsvansker, ikke uthvilt etter søvn, endret søvnmønster

4. Smerter (eller ubehag) som ofte er utbredte og vandrende av natur. Muskelsmerter, leddsmerter og hodesmerter av ny type, mønster eller intensitet

5. Minst to nevrologiske/kognitive symptomer
a. Svekket konsentrasjon og hukommelse
b. Forvirret
c. Desorientert
d. Vansker med å bearbeide informasjon
e. Problemer med å kategorisere informasjon og finne ord
f. Sanseforstyrrelser, vanskelig å fokusere synet, nummenhet/kuldefølelse

\section{Minst ett symptom fra to av de følgende tre kategorier}

\section{a. Autonome utfall}
i. Blodtrykksfall ved overgang fra liggende til stående stilling
ii. Drastisk økt hjertefrekvens ved overgang fra liggende til stående stilling
iii. Blodtrykksfall etter å ha stått oppreist en stund
iv. Ørhet
v. Ekstrem blekhet, kvalme og irritabel tarm
vi. Skjelvinger med eller uten hjertebankfølelse
vii. Kortpustethet
viii. Blæreforstyrrelser

\section{b. Nevroendokrine utfall}
i. Forstyrret termostabilitet: unormal kroppstemperatur og tydelige døgnvariasjoner, svettetokter, feberfølelse og kalde esktremiteter
ii. Intoleranse for ekstrem hete og kulde
iii. Markert vektendring - anoreksi eller unormal appetitt
iv. Tap av adaptasjonsevne
v. Forverring av symptomer ved stress/belastninger 
c. Immunologiske utfall

i. Ømme lymfeknuter

ii. Gjentakende sår hals

iii. Gjentakende influensafølelse

iv. Generell sykdomsfølelse

v. Overfølsomhet for mat, medisiner og/eller kjemikalier

7. Sykdommen vedvarer i minst seks måneder. Den har vanligvis en klar identifiserbar begynnelse selv om den kan være gradvis. Tre måneders varighet er tilstrekkelig for barn.

\section{Eksklusjonstilstander}

Pågående sykdomsprosesser, inkludert primære psykiatriske lidelser og rusmisbruk, som kan forklare de fleste symptomene på utmattelse, søvnforstyrrelser, smerte og kognitive forstyrrelser utelukker diagnosen kronisk utmattelsessyndrom.

Eksempler på slike sykdommer er: Addisons sykdom, Cushings sykdom, hypo- eller hyperthyreose, jernmangel, hemochromatose, diabetes mellitus, kreft, søvnforstyrrelsessykdommer, revmatiske lidelser, immunsykdommer, nevrologiske sykdommer som multippel sclerose, enkelte infeksjonssykdommer, primære psykiatriske lidelser og rusmisbruk. 


\section{Vedlegg 2}

\section{Utredningsskjema etter CDC1994 Fukudakriteriene}

Hovedkriterier (alle skal være oppfylt)

a) Har en varighet på minst 6 måneder

b) Er vedvarende eller tilbakevendene

c) Er nyoppstått eller har en klar begynnelse

d) Resulterer i en vesentlig reduksjon i arbeids, utdannings, samt sosiale og personlige aktiviteter

e) Bedres ikke av hvile

f) Ikke er et resultat av pågående anstrengelse

Tilleggskriterier (minst 4 av 8 må være oppfylt)

- Selvrapportert svekkelse i korttidshukommelsen eller konsentrasjonen alvorlig nok til å forårsake vesentlig reduksjon i arbeids-, samt sosiale og personlige aktiviteter

- Hyppig og tilbakevendende sår hals

- Ømme lymfeknuter

- Muskelsmerter

- Migrerende leddsmerter uten hevelse eller rødme

- Hodepine (ny type, nytt mønster og intensitet)

- Manglende følelse av å være uthvilt etter søvn

- Forverret sykdomsfølelse i minst 24 timer etter anstrengelse

\section{Eksklusjonskriterier iflg CDC1994 kriterier}

1) Medisinske tilstander som fører til kronisk tretthet som f.eks:

a) Ubehandlet/underbehandlet avt stoffskifte

b) Søvnforstyrrelser

c) Medikamentbivirkninger

2) Tidligere diagnostiserte medisinske tilstander uten medisinsk forsvarlig dokumentert opphør og hvor tilstedeværelsen av tilstanden kan forklare den kroniske utmattelsen. Slike tilstander inkluderer:

a) Nylig behandlet kreft

b) Kroniske tilfeller av hepatitt B eller C

c) HIV

3) Tidligere eller nåværende diagnose av
a) Alvorlig depressiv lidelse
b) Bipolar lidelse
c) Schizophreni
d) Ulike vrangforestillinger (paranoia)
e) Demens
f) Anoreksia nervosa
g) Bulimia nervosa

4) Alkohol eller stoffmisbruk fra og med de to siste år før den kronisk utmattelsen

5) Sykelig overvekt 


\section{Vedlegg 3}

\section{Utredningsskjema i henhold til Pediatrisk kriterier (Jason, 2006)}

1. Klinisk vurdert, uforklarlig, vedvarende eller tilbakevendende (residiverende) kronisk utmattelse i løpet av de siste tre månedene som ikke skyldes pågående anstrengelse, ikke lindres av hvile og som medfører en betydelig reduksjon i aktivitetsnivået

2. Anstrengelsesutløst sykdomsfølelse og/eller utmattelse. Ved hvilken som helst type aktivitet må det oppstå et tap av fysisk eller psykisk utholdenhet, rask/plutselig muskulær eller kognitiv utmattelse og en tendens til forverring av andre assosierte symptomer hos pasienten. Restitusjonen er vanligvis langsom, og tar ofte 24 timer eller mer

3. Søvn. Ikke-uthvilende søvn eller forstyrrelser i søvnkvalitet eller rytme. Kan inkludere økt søvnbehov, forstyrret søvn og/eller forandret døgnrytme

4. Smerte. Minst ett symptom fra følgende:

a) Muskel- og leddsmerter

b) Magesmerter og/eller hoderelaterte smerter

\section{To eller flere nevrokognitive utfall}
a) Svekket hukommelse
b) Problemer med å holde fokus
c) Vansker med å finne riktige ord
d) Glemmer ofte hva man ønsket å si
e) Åndsfraværende
f) Langsom tankegang
g) Problemer med å gjengi/huske informasjon
h) Kan bare fokusere på en ting om gangen
i) Problemer med å uttrykke tanker
j) Problemer med å forstå informasjon
k) Mister ofte tråden i en tankerekke
I) Nyoppståtte vansker med matematikk eller andre skolefag

6. Minst ett symptom fra to av de følgende tre kategorier

a) Autonome manifestasjoner (blodtrykksfall, økt hjertefrekvens, svimmelhet, forstyrret balanse, kortpustethet)

b) Nevroendokrine utfall (feberfølelse og kalde ekstremiteter, unormal kroppstemperatur og tydelige døgnvariasjoner, svettetokter, intoleranse for hete og kulde, markert vektendring, forverring av symptomer ved stress/overbelastning)

c) Immunologiske manifestasjoner (hyppig influensafølelse, sår eller irritert hals, stadige perioder med feber og hetetokter, ømme, men ikke spesielt hovne lymfeknuter, ny overfølsomhet for mat, lukt eller kjemikalier)

\section{Eksklusjonskriterier}

1) Enhver pågående medisinsk tilstand som kan forklare tilstedeværelsen av kronisk utmattelse

2) Noen pågående psykiatriske tilstander som kan forklare tilstedeværelsen av kronisk utmattelse
a) Barneschizophreni
b) bipolar lidelse
c) pågående alkohol- eller stoffmisbruk,
d) Anorexia nervosa eller bulimia nervosa
e) Alvorlige depressive lidelser 


\section{Ikke-ekskluderende tilstander}

Barn kan ha tilstedeværelse av medvirkende tilstander som ikke godt nok forklarer utmattelsen, og som derfor ikke nødvendigvis er eksklusjonsgrunner:

1) Psykiske lidelser som angst, somatoforme lidelser og depressive lidelser

2) Andre tilstander som primært er karakterisert ved symptomer som ikke kan bekreftes av diagnostiske laboratorietester

3) En hvilken som helst tilstand/lidelse hvor spesifikk behandling tilstrekkelig lindrer alle de tilhørende symptomene og hvor behandlingen er tilfredsstillende dokumentert

4) En hvilken som helst tilstand/lidelse som er blitt behandlet med spesifikk terapi før utviklingen av kronisk symptomatisk følgetilstand

5) En hvilken som helst isolert og uforklart klinisk undersøkelse, samt laboratorietest eller billeddiagnostiske tester som er utilstrekkelig til å kunne indikere eller bekrefte tilstedeværelsen av en eksklusjonstilstand 


\section{Nasjonal kompetansetjeneste for CFS/ME}

Oslo universitetssykehus, Kvinne og barneklinikken

Leder; overlege dr. med. Ingrid B. Helland

Barneavdelingen for nevrofag

Telefonnummer til nasjonal kompetansetjeneste: 23072790 http://WWW.oslo-universitetssykehus.no/kompetanseCFSME E-post: kompetansecfsme@ous-hf.no

\section{Oppgaver for nasjonale kompetansetjenester}

Nasjonale kompetansetjenester skal ivareta følgende oppgaver innenfor sitt ansvarsområde:

- Bygge opp og formidle kompetanse.

- Overvåke og formidle behandlingsresultater.

- Delta i forskning og etablering av forskernettverk.

- Bidra i relevant undervisning.

- Sørge for veiledning, kunnskaps- og kompetansespredning til helsetjenesten, andre tjenesteytere og brukere.

- Iverksette tiltak for å sikre likeverdig tilgang til nasjonale kompetansetjenester.

- Bidra til implementering av nasjonale retningslinjer og kunnskapsbasert praksis.

- Etablere faglige referansegrupper.

- Rapportere årlig til departementet eller til det organ som departementet bestemmer. 


\section{Helsedirektoratet}

Pb. 7000 St Olavs plass, 0130 Oslo

TIf.: 81020050

Faks: 24163001

www.helsedirektoratet.no

Oslo, februar 2014 